\title{
Guinea: Selected Issues and Statistical Appendix
}

This Selected Issues paper and Statistical Appendix for Guinea was prepared by a staff team of the International Monetary Fund as background documentation for the periodic consultation with the member country. It is based on the information available at the time it was completed on December 2, 2005. The views expressed in this document are those of the staff team and do not necessarily reflect the views of the government of Guinea or the Executive Board of the IMF.

The policy of publication of staff reports and other documents by the IMF allows for the deletion of market-sensitive information.

To assist the IMF in evaluating the publication policy, reader comments are invited and may be sent by e-mail to publicationpolicy@imf.org.

Copies of this report are available to the public from

International Monetary Fund $\bullet$ Publication Services

700 19th Street, N.W. • Washington, D.C. 20431

Telephone: (202) $6237430 \bullet$ Telefax: (202) 6237201

E-mail: publications@imf.org • Internet: http://www.imf.org

Price: $\$ 15.00$ a copy

\section{International Monetary Fund Washington, D.C.}





\section{INTERNATIONAL MONETARY FUND}

\section{GUINEA}

\section{Selected Issues and Statistical Appendix}

Prepared by a staff team consisting of Messrs. I. de la Piedra (head), P. Dudine, M. Gorbanyov, D. Jones (Resident Representative), and F. Nsengiyumva (all AFR)

Approved by African Department

December 2, 2005

\section{Contents}

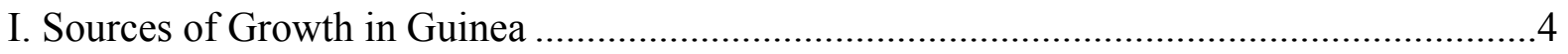

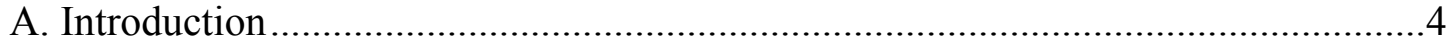

B. Trends and Sectoral Contribution to GDP Growth .................................................

C. Growth Accounting Regression .............................................................................

D. Growth, Exogenous Shocks, and Policy Changes ………………………...............11

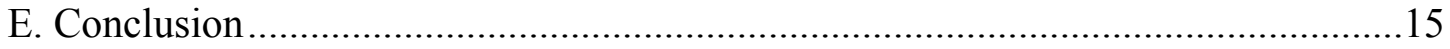

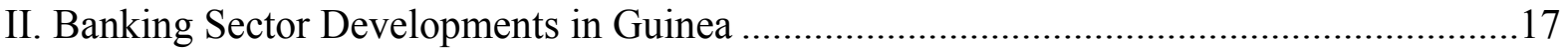

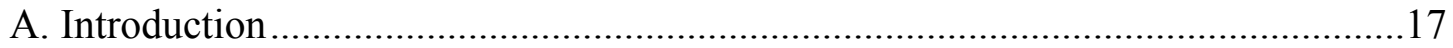

B. Overview of the Banking Sector and Financial Markets .......................................17

C. Banks in the Foreign Exchange Market ...............................................................23

D. Dollarization of the Economy and Interest Rate Structure .....................................25

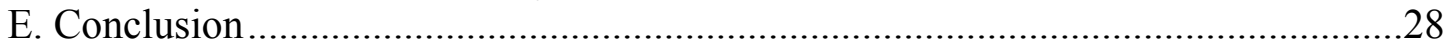

III. Competitiveness and Equilibrium Exchange Rate in Guinea ……....................................30

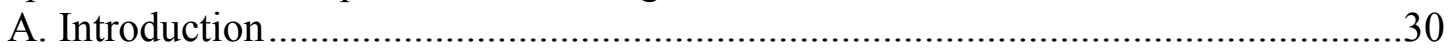

B. Background and Recent Developments ...................................................................30

C. Estimating the Long-Run Equilibrium Exchange Rate.............................................33

D. Alternative Indicators of Guinea's External Competitiveness...................................37

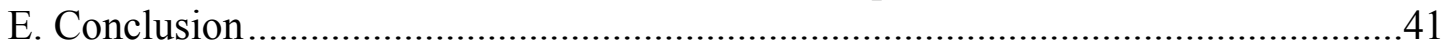

Tables

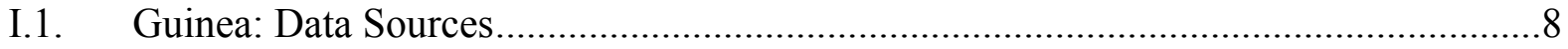

I.2. Guinea: Dickey-Fuller Test for Unit Root of $\mathrm{y}, \mathrm{k}$, and 1...........................................

I.3. Guinea: Johansen Test for Cointegration of $\mathrm{y}, \mathrm{k}$, and 1 ..............................................

I.4. Guinea: Estimate of Production Function................................................................10

I.5. Guinea: Contribution to Growth of Capital Accummulation and Labor Growth .........11

I.6. Guinea: Growth, Deficit, and Changes in Terms of Trade ……………….................15 
II.1. Banking System Structure, Mid-2005 ..................................................................18

II.2. Selected Indicators of Microfinance Institutions, 2002-04 ......................................18

II.3 Guinea: Financial Soundness Indicators of the Banking Sector, 2002-June 2005......19

II.4. Structure of Credit Portfolio of the Commercial Banks, 2002-June 2005...................20

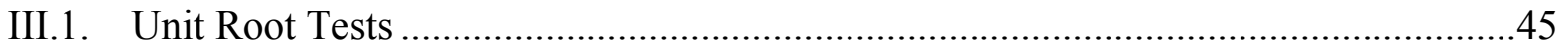

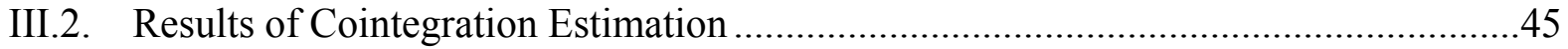

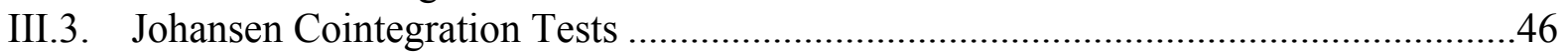

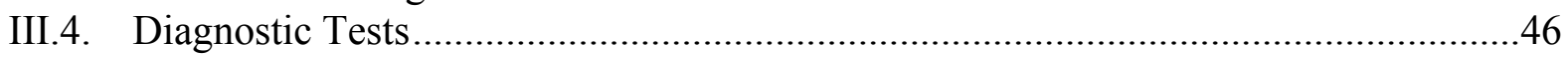

III.5. Guinea's Rank on Indicators of Business Environment and Governance During

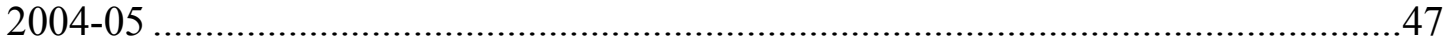

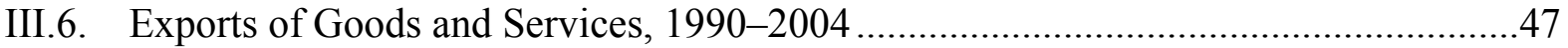

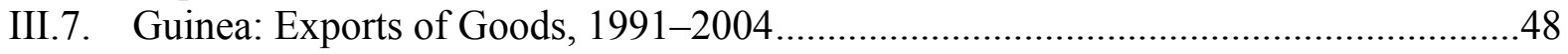

Figures

I.1. Guinea: Annual Real GDP Growth, 1992-2004..................................................

I.2. Guinea: Composition of GDP at Constant 1996 Prices, 1991-2004..............................

I.3. Guinea: Real Rate of Growth by Sector, 1992-2004 ...............................................

I.4. Guinea: Sectoral Contribution to Real GDP Growth, 1992-2004 ...............................6

I.5. Guinea: Sources and Uses of GDP at 1996 Prices, 1991-2004 ...................................

I.6. Regional Instability and GDP Growth in Guinea, 1996-2004 ..................................12

I.7. Guinea: Terms of Trade and GDP Growth, 1992-2004 ..........................................13

I.8. Guinea: Growth and Fiscal Deficit, 1992-2004 .....................................................14

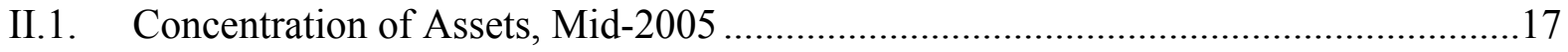

II.2. Banks' Assets and Liabilities, 2002-05 ………........................................................18

II.3. Exchange Rates Before and After the Market Unification Reform ............................22

II.4. Government Securities: Volumes and Interest Rates, 2001:Q2-2005:Q2 ..................23

II.5. Currency Depreciation and Dollarization of Assets, 1998-2005 ...............................25

II.6. Deposit and Lending Operations of the Banks, Selected Indicators, January 2002 -

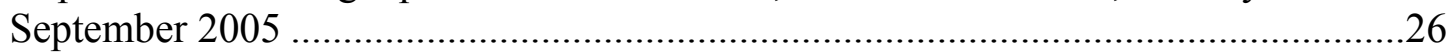

II.7. Interest Rates Structure and Inflation, January 2002-September 2005 .......................27

II.8. Exchange and Interest Rates, January 2004-September 2005 ..................................27

III.1. Real Effective Exchange Rate, 1975-2004 ……...................................................33

III.2. Guinea: Actual and Equilibrium Exchange Rate, 1980-2004 …................................37

III.3. Guinea: Internal and External Real Exchange Rate, 1986-2004 .................................39

III.4. Guinea's Rank on Indicators of Business Environment, 2004-05 ................................40

III.5. Guinea: Evolution of Governance Indicators, 1996-2004 ……................................41

III.6. Governance Indicators, Comparison of Guinea with Sub-Saharan Africa ....................41

Boxes

II.1. Preconditions for a Successful Liberalization of Foreign Exchange Market ..............21 
Statistical Appendix Tables

1. Guinea: Selected Social and Demographic Indicators..............................................49

2. Guinea: Selected Economic and Financial Indicators, 2000-04 ...............................50

3. Guinea: GDP at Current Prices by Demand Component, 2000-04 ............................51

4. Guinea: GDP at Constant 1996 Prices by Sector, 2000-04 .......................................52

5. Guinea: Consumer Price Index, 2000-04 (Period average) …………………............53

6. Guinea: Consumer Price Index, 2000-04 (End of period) ……………………..........54

7. Guinea: Financial Operations of the Central Government, 2000-04 ...........................55

8. Guinea: Central Government Revenue, 2000-04 ................................................56

9. Guinea: Central Government Expenditure, 2000-04 ………...................................57

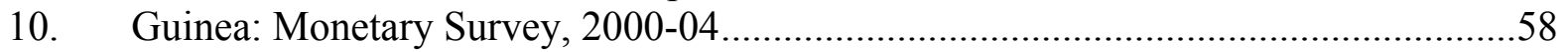

11. Guinea: Summary Accounts of the Central Bank, 2000-04 ...................................5

12. Guinea: Summary Accounts of Deposit Money Banks, 2000-04 ..............................60

13. Guinea: Distribution of Banking Sector Credit by Sector and Maturity, 2000-04 ......61

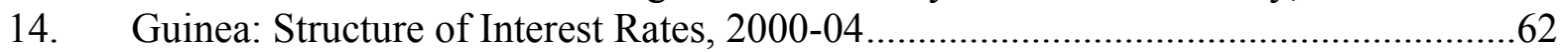

15. Guinea: Balance of Payments, 2000-04 ………………………..........................63

16. Guinea: Composition of Merchandise Exports, 2000-04 .........................................64

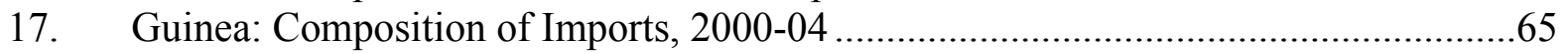

18. Guinea: Direction of Trade-Exports, 2000-04 ....................................................66

19. Guinea: Direction of Trade-Imports, 2000-04 ………….....................................67

20. Guinea: External Public Debt, 2000-04 ………....................................................68

21. Guinea: External Debt Service, 2000-04 ………............................................69

22. Guinea: Debt-Service Liabilities on Medium- and Long-Term External Public Debt,

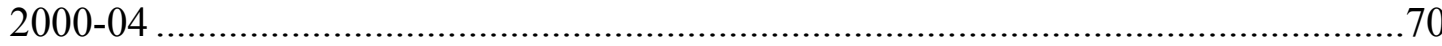

23. Guinea: Nominal Exchange Rates and Effective Exchange Rate Indices, 2000:Q12004:Q4 ................................................................................................

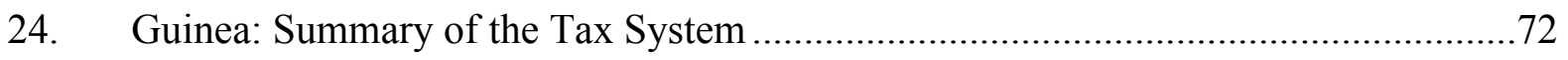

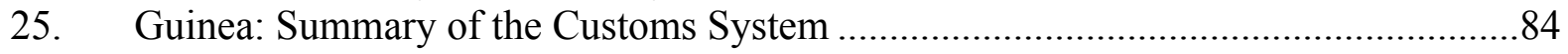




\section{SOURCES OF GRoWTh IN GUINEA ${ }^{1}$}

\section{A. Introduction}

1. During the 1990s, Guinea's economy grew steadily at an average annual rate of more than 4 percent, one of the highest rates in West Africa. Beginning in 2000, the pace of GDP growth slowed to 2.7 percent a year on average, and annual growth rates started to display a larger variability. In the period 2000-04, the macroeconomic scenario was exacerbated by a predominant state of insecurity in the region, a fall in the price of bauxite (Guinea's main export commodity), and a sharp increase in the prices of imported goods. At the same time, whereas inflation and the fiscal deficit were under control during the 1990s, in 2000 the fiscal deficit started to increase as a percentage of GDP, the exchange rate to deteriorate, and inflation to rise.

2. This paper examines the sources of real growth in Guinea. The objective of the paper is to identify and quantify the impact on real GDP growth of both the exogenous shocks and the policy changes that have occurred since 2000. The paper offers, first, some empirical evidence on real GDP growth in Guinea and then analyzes the sources of growth using the standard framework of growth accounting. Finally, the paper analyzes and quantifies the effect that some exogenous shocks and policy changes have had on growth.

3. The paper reaches two conclusions. First, changes in the overall macroeconomic environment (both exogenous shocks and changes in policy) have hampered growth since 2000. Estimates indicate that these changes had a negative impact of 0.4 percentage points on average annual GDP growth, against a positive contribution of over 1 percentage point in the period 1995-99. The second conclusion is that changes in macroeconomic policies alone had a negative impact of about 0.6 percentage point on the average annual growth rate. Although there is evidence that some exogenous shocks negatively affected growth, their impact cannot be robustly quantified.

4. The paper is organized as follows. Section B studies the trends of GDP growth and the sectors that most contributed to it. Section $\mathrm{C}$ presents a growth accounting analysis and quantifies the contribution of production factors to growth. Section D describes and quantifies the impact that exogenous shocks and policy changes have had on growth since 2000. Section E concludes.

\section{B. Trends and Sectoral Contribution to GDP Growth}

5. During 1992-99, Guinea's real GDP grew steadily at an average annual rate of 4.4 percent, against an average growth rate of 3.8 percent for the West African Economic and Monetary Union (WAEMU). ${ }^{2}$ In 1996-99 alone, Guinea achieved an average annual growth

\footnotetext{
${ }^{1}$ Prepared by Paolo Dudine.

${ }^{2}$ Although Guinea is not a member of WAEMU, it provides a useful set of comparator countries.
} 
rate of 4.7 percent, against a WAEMU average of 3.5 percent. Growth was both robust and stable during this period, with the standard deviation of the annual growth rate being only 0.62 (see Figure I.1).

6. During 2000-04, the average annual growth rate in Guinea declined to 2.7 percent. After a weak performance in 2000, real GDP growth recovered in 2001 and then started to decline until it reached an 11-year-low of 1.4 percent in 2003. As Figure I.1 shows, not only was growth less strong, but it was also more volatile; the standard deviation of the annual growth rate increased to 1.04 .

7. The sectoral composition of $\mathrm{GDP}^{3}$ has remained almost stable since 1990 (see Figure I.2). The GDP share of the secondary sector has been growing at the expense of the tertiary sector, but these changes have been mild, and no structural change in GDP composition can be said to have occurred. In 2004, the value added in the primary sector amounted to roughly 20 percent of GDP, that in the secondary sector to 30 percent, and that in the tertiary sector to 50 percent.

8. Despite the stability of the sectoral composition of GDP, the sectoral contributions to annual GDP growth have varied considerably from year to year, reflecting unstable sectoral growth in each sector. As an example, compare the growth pattern of the tertiary sector with that of the secondary sector. Between 2000 and 2004 , the tertiary sector grew steadily at an average annual rate of only 2 percent, against a steady average of
Figure I.1. Guinea: Annual Real GDP Growth, 1992-2004 (In percent)

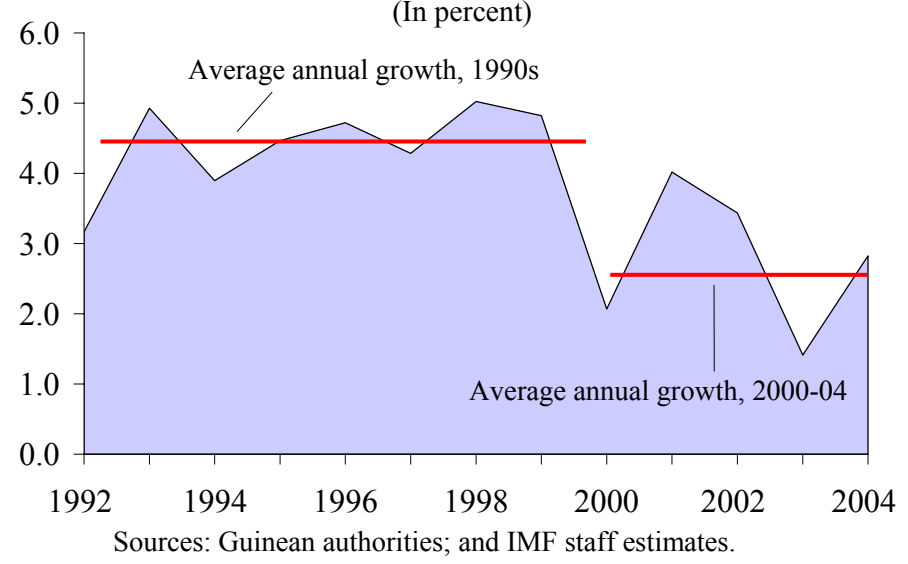

Figure I.2. Guinea: Compostion of GDP at Constant 1996 Prices, 1991-2004 (In percent)

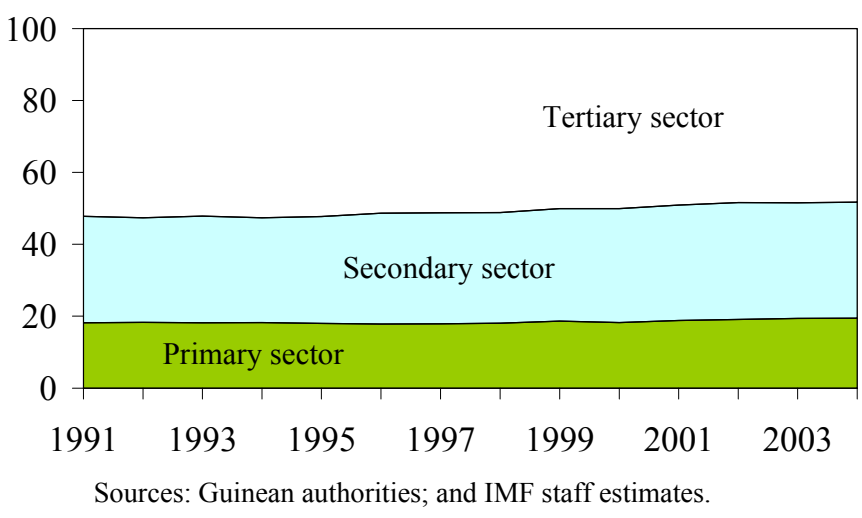

Figure I.3. Guinea: Real Rate of Growth by Sector, 1992-2004

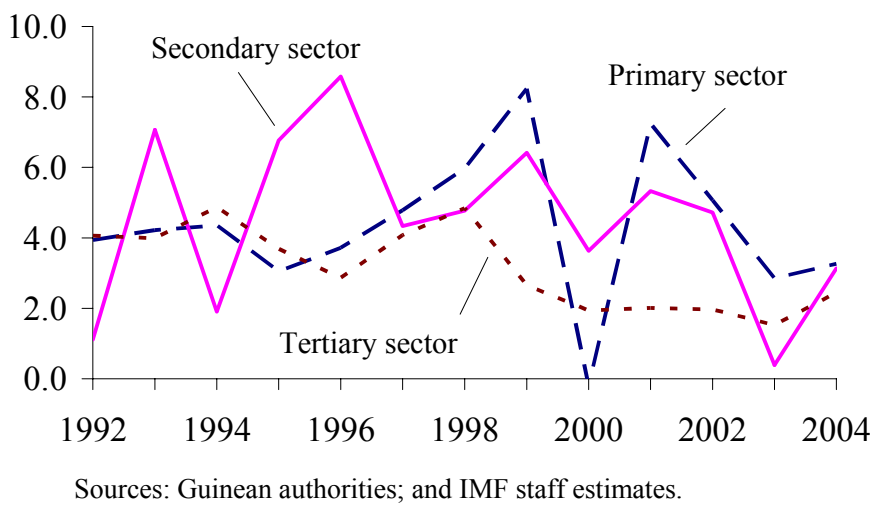

${ }^{3}$ GDP is measured at factor costs in constant 1996 prices. 
4 percent a year during 1992-99 (see Figure I.3). This translated into a reduction of its contribution to overall GDP growth (see Figure I.4) and into a slight reduction of its share of GDP (see Figure I.2). On the contrary, growth in the secondary sector has been very unstable over time. This implied that the contribution of the secondary sector to overall GDP has also been unstable, and that the share of the secondary sector to GDP has remained fairly stable. Similarly, between 2001 and 2004 the primary sector grew more strongly than the other two sectors. Despite this, its contribution to growth remained limited, owing to its size relative to GDP.

9. The structure of GDP absorption changed after 2000. Data on the uses and sources of GDP reveal that, between 1991 and 1999, investment accounted for 22 percent of GDP, and consumption for 85 percent of GDP, with the trade deficit accounting for 7 percent. In 2000 (see Figure I.5) investment began to drop as a percentage of GDP, recording a 15-year low of 8.6 percent in 2003. After 2000, consumption absorbed, on average, 91 percent of GDP, investment 11 percent, and the trade deficit represented, on average, 2 percent of GDP. At the same time, savings decreased as a percentage of GDP, from an average of 15 percent during 199199 to 9 percent during 2000-04.

10. The overall picture that emerges from this analysis is that, after 2000, growth suffered from a decrease in investment, a large volatility in the growth of the secondary and primary sectors, and a decline of growth in the tertiary sector. In particular, a lack of diversification in the secondary sector, where mining plays a dominant role, has made the country vulnerable to volatility in the international prices of

Figure I.4. Guinea: Sectoral Contribution to Real GDP Growth, 1992-2004 (Percentage points)

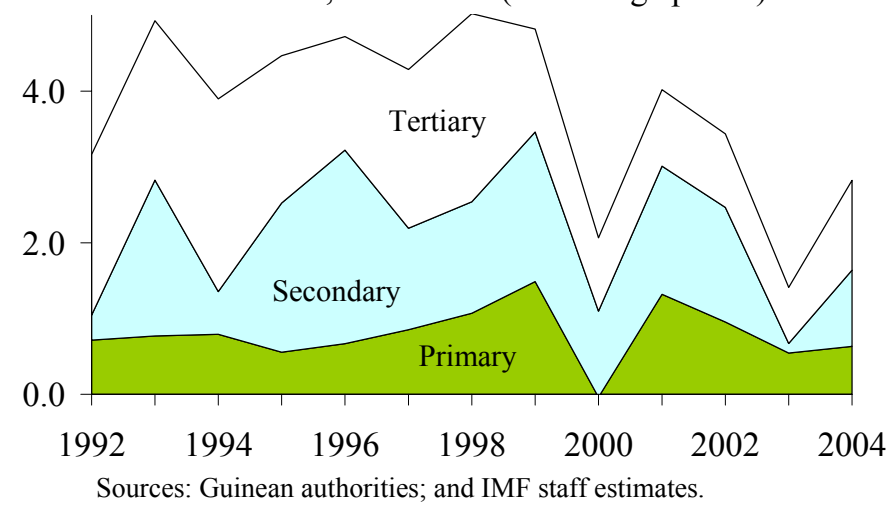

Figure I.5. Guinea: Sources and Uses of GDP at 1996 Prices, 1991-2004 (Trillions of Guinean francs)

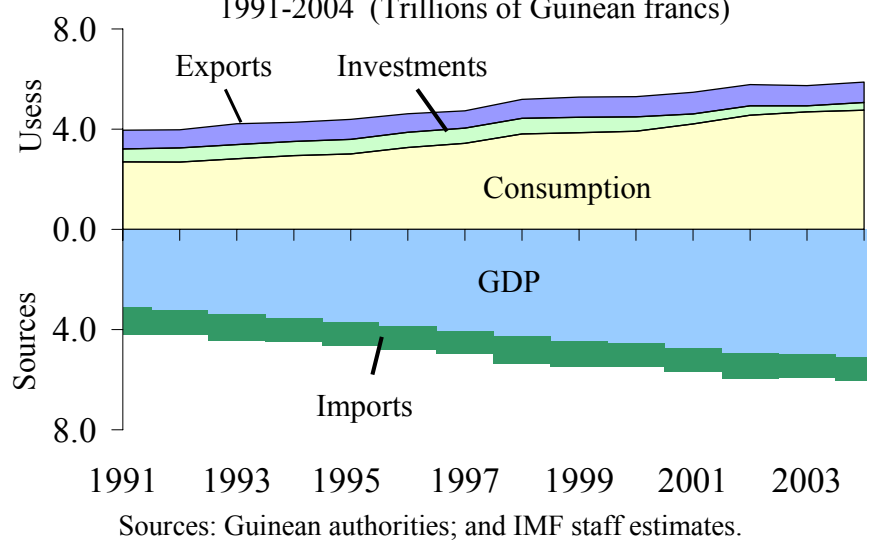
bauxite. Finally, the expansion of consumption against a decrease in investment and savings reduced capital accumulation and growth and created financing needs that further exposed the country to shocks. The next two sections discuss the factors behind these changes. First, a growth accounting exercise is conducted, so as to identify how capital accumulation and labor growth affected economic growth in Guinea. Second, some specific exogenous shocks and policy changes will be considered. 


\section{Growth Accounting Regression}

11. Growth accounting is a widely used methodology to analyze the sources of growth in a country. It aims at separating the changes in output that can be attributed to changes in the stock of physical capital, increases in the workforce, and changes in total factor productivity (TFP). Because TFP is intended to capture how institutional and exogenous variables, as well as macroeconomic and structural policies, affect overall productivity, growth accounting still remains one of the tools that can most effectively describe the structure of an economy's productive capacity and detect how changes in the macroeconomic scenario affect growth.

\section{The basic framework}

12. The most common building block of the growth accounting technique is the following aggregate production function:

$$
Y_{t}=A_{t} K_{t}^{\alpha} L_{t}^{\beta}
$$

where $Y_{t}$ is output, $K_{t}$ is physical capital, $L_{t}$ is the labor force, and $A_{t}$ is the level of TFP.

13. A convenient transformation of equation (1) consists in taking the natural logarithm of both sides to obtain

$$
y_{t}=a_{t}+\alpha k_{t}+\beta l_{t},
$$

where lower-case letters represent the natural logarithm of a variable. The convenience of this transformation is that, by taking first differences, one obtains

$$
\Delta y_{t}=\Delta a_{t}+\alpha \Delta k_{t}+\beta \Delta l_{t},
$$

where $\Delta$ indicates the increase at time $t$ of the natural logarithm of a variable and, thus, its rate of growth. Equation (3) implies that once $\alpha$ and $\beta$ are determined, it is possible to separate the share of real GDP growth determined by an increase in the stock of capital from the share determined by an increase in the labor force, yielding the impact of TFP as a residual.

14. Our estimation of equation (2) is based on regression analysis. We assumed that the parameters $\alpha$ and $\beta$ are constant and unknown and that $a_{t}$ is a random error term (possibly with a non zero mean) intended to capture the effect on growth of all exogenous and policy variables. We used data on the level of physical capital and the size of the labor force to estimate the coefficients $\alpha$ and $\beta$.

\section{Data description and preliminary tests}

15. Equation (2) was estimated on the basis of data obtained from the World Economic Outlook for the years 1970-2004 (see Table I.1). For the output variable $Y$, we used the series of GDP at constant 2000 prices. The series for the stock of capital $K$ was constructed using the perpetual inventory method, according to which

$$
K_{t}=K_{t-1}(1-\delta)+I_{t},
$$


where $\delta$ is the rate of physical depreciation of capital, and $I_{t}$ is the level of gross investment. For lack of sufficiently long series, the series of gross investment was constructed from the series of gross national savings, exports, and imports of goods and services, according to the accounting identity

$$
I_{t}=S_{t}-N X_{t}
$$

All series were available only in current prices. To obtain a series of investment in constant prices, we deflated the series of savings by the consumer price index (CPI), the series of imports by the deflator for import prices, and the series of exports by the deflator for export prices. Years for which $I_{t}$ results negative were dropped. As a result, the series of investment and capital starts in 1975 . We obtained the level of capital in the first period, $K_{0}$, by assuming a capital-output ratio of 1.5, which is in line with assumptions made in other studies on similar countries. The rate of physical depreciation of capital $\delta$ was assumed to be 12 percent. Because of a lack of data, we used the series of total population of ages 15-64 for labor, $L$, as an approximation of the size of the available labor force. The series of labor force was not adjusted to include accumulation of human capital. Finally, for each of the series, we took the natural logarithm to obtain series for the variables $y, k$, and $l$.

16. Before estimating equation (2), we conducted a cointegration test to establish whether there exists any long-run stable relationship among the variables. A first necessary step is to determine whether each of the series $y, k$, and $l$ is stable, either in values or in first differences. We conducted Dickey-Fuller tests on each of the three series, and we found that all three series are stationary only if expressed in first differences (see Table I.2). This finding allowed us, as a second step, to use the Johansen methodology (or trace test) to determine the existence of a cointegration vector among the three variables. The existence of such a vector indicates the existence of a long-run stable relationship among the variables. The Johansen test leads us to accept the hypothesis that one cointegration vector exists (see Table I.3), and this finally allowed us to estimate equation (2) with a simple OLS.

Table I.1. Guinea: Data Sources

\begin{tabular}{lccc}
\hline Series & Range & Data Set & Code \\
\hline GDP at constant 2000 prices & $1970-2004$ & WEO & W 656 NGDP_R \\
GDP at current prices & $1970-2004$ & WEO & W 656 NGDP \\
Overall fiscal balance, cash basis & $1970-2004$ & WEO & W 656 GCB \\
Terms of trade & $1970-2004$ & WEO & W 656 TTT \\
Savings, in current prices & $1970-2004$ & WEO & W 656 NGS \\
Imports of goods and services, in current prices & $1970-2004$ & WEO & W 656 NM \\
Exports of goods and services, in current prices & $1970-2004$ & WEO & W 656 NX \\
Deflator of imports prices, goods and services & $1970-2004$ & WEO & W 656 TM_D \\
Deflator of exports prices, goods and services & $1970-2004$ & WEO & W 656 TX_D \\
CPI (2000 = 100) & $1970-2004$ & WEO & W 656 PCPI \\
Total population & $1970-2004$ & WEO & W 656 LP \\
Percentage of population of age 15- 64 & $1970-2004$ & WB Development Indicators & SP.POP.1564.IN.ZS \\
\hline
\end{tabular}


Table I.2. Guinea: Dickey-Fuller Tests for Unit Root of y, k, and 1

\begin{tabular}{c|c|c|ccc}
\hline & $\begin{array}{c}\text { Number of } \\
\text { Variable }\end{array}$ & Test Statistic & $\begin{array}{c}1 \% \text { Critical } \\
\text { Value }\end{array}$ & $\begin{array}{c}5 \% \text { Critical } \\
\text { Value }\end{array}$ & $\begin{array}{c}10 \% \text { Critical } \\
\text { Value }\end{array}$ \\
\hline$y$ & 34 & 0.616 & -3.689 & -2.975 & -2.619 \\
$\Delta y$ & 33 & -7.886 & -3.696 & -2.978 & -2.620 \\
$k$ & 29 & -0.398 & -3.723 & -2.989 & -2.625 \\
$\Delta k$ & 28 & -5.289 & -3.73 & -2.992 & -2.626 \\
$l$ & 34 & -1.121 & -4.297 & -3.564 & -3.218 \\
$\Delta l$ & 33 & -3.023 & -3.696 & -2.978 & -2.62 \\
\hline
\end{tabular}

Table I.3. Guinea: Johansen Tests for Cointegration of $\mathrm{y}, \mathrm{k}$, and 1

\begin{tabular}{ccccccc}
\hline \multicolumn{2}{l}{$\begin{array}{l}\text { Trend: constant } \\
\text { Sample: }\end{array}$} & $1976-2004$ & & \multicolumn{3}{c}{$\begin{array}{c}\text { Number of obs. }=29 \\
\text { Lags }=1\end{array}$} \\
\hline $\begin{array}{c}\text { Maximum } \\
\text { Rank }\end{array}$ & Parameters & $\begin{array}{c}\text { Log- } \\
\text { likelihood }\end{array}$ & Eigenvalue & $\begin{array}{c}\text { Trace } \\
\text { Statistic }\end{array}$ & $\begin{array}{c}5 \% \text { Critical } \\
\text { Value }\end{array}$ & $\begin{array}{c}\text { 1\% Critical } \\
\text { Value }\end{array}$ \\
\hline 0 & 3 & 210.717 & & 40.532 & 29.68 & 35.65 \\
1 & 8 & 225.298 & 0.6342 & 11.371 & 15.41 & 20.04 \\
2 & 11 & 230.835 & 0.3174 & 0.297 & 3.76 & 6.65 \\
3 & 12 & 230.983 & 0.0102 & & & \\
\hline
\end{tabular}

\section{Estimation results}

17. The OLS estimation of equation (2) produced the following long-run relationship between real GDP, capital, and the work force:

$$
y=-4.9+0.3 k+0.7 l+a \text {. }
$$

All coefficients proved to be significantly different from zero (see Table I.4). The hypothesis of constant returns to scale (i.e. $\alpha+\beta=1$ ) was tested and could not be rejected. A potential problem arising from how the series of capital was constructed could be that the estimator of $\alpha$ is biased. We conducted robustness checks by changing the initial capital/output ratio and the rate of depreciation of capital and by using total population instead of total population of ages $15-64$. The estimates were found to be almost the same as those in equation (6) under all of these changes. 
Table I.4. Guinea: Estimate of Production Function

\begin{tabular}{|c|c|c|c|c|c|}
\hline \multicolumn{6}{|c|}{$y_{t}=c+\alpha k_{t}+\beta l_{t}+\varepsilon_{t}$} \\
\hline & & Symbol & Coeff. & $t$ & $P>|t|$ \\
\hline Constant & & $c$ & $\begin{array}{c}-4.952 \\
(0.701)\end{array}$ & -7.060 & 0.000 \\
\hline Capital & & $k$ & $\begin{array}{c}0.307 \\
(0.075)\end{array}$ & 4.060 & 0.000 \\
\hline Labor & & $l$ & $\begin{array}{c}0.705 \\
(0.089)\end{array}$ & 7.900 & 0.000 \\
\hline N. of observations & 30 & & & & \\
\hline$F(2,27)$ & $2,805.97$ & & & & \\
\hline Prob $>$ F & 0.000 & & & & \\
\hline R-squared & 0.99 & & & & \\
\hline
\end{tabular}

Notes: Sources of data are described in Table I.1.

18. The interpretation of equation (6) is that an increase of 1 percent in the level of physical capital translates into an increase of 0.3 percent in real GDP, while a 1 percent increase in the labor force increases real GDP by 0.7 percent (notice that the constant term disappears when taking first differences). Discrepancies between actual growth rates and predicted growth rates are attributable to changes in TFP. The estimated elasticity of output to capital in equation (6) is lower than (but consistent with) that for other sub-Saharan countries, where estimates of $\alpha$ range around $0.4 .^{4}$ It is worth noticing that the estimates presented in equation (6) are consistent with evidence presented in Section B about the composition of the Guinean economy, where the capital-intensive secondary sector contributes to around 30 percent of GDP, and where the labor-intensive secondary and tertiary sectors represent the remaining 70 percent.

19. On the basis of estimated equation (6), we obtain the decomposition of growth reported in Table I.5. From the decomposition, it appears that the average contribution to growth from increases in the stock of capital fell from 1.4 percentage points during 1995-99 to 0.65 percentage points during 2000-04. This result is consistent with the evidence presented in Section B that investment has declined as a share of GDP.

\footnotetext{
${ }^{4}$ Senhadji (2000), Akitoby and Cinyabuguma (2004), and Barro and Sala-i-Martin (1995).
} 
Table I.5. Guinea: Contribution to Growth of Capital Accumulation and Labor Growth

\begin{tabular}{|c|c|c|c|c|}
\hline \multirow{2}{*}{$\alpha=0.3$} & \multirow{2}{*}{$\begin{array}{l}\text { Average Real } \\
\text { Growth }\end{array}$} & \multicolumn{3}{|c|}{ Contribution of } \\
\hline & & Capital & Labor & TFP \\
\hline $1975-1979$ & 2.39 & 1.02 & 1.39 & -0.10 \\
\hline 1980-1984 & 1.52 & 0.43 & 1.49 & -0.40 \\
\hline 1985-1989 & 4.24 & 1.58 & 1.76 & 0.88 \\
\hline 1990-1994 & 3.77 & 1.22 & 3.56 & -1.03 \\
\hline 1995-1999 & 4.69 & 1.38 & 2.15 & 1.14 \\
\hline $2000-2004$ & 2.75 & 0.65 & 2.50 & -0.40 \\
\hline \multirow{2}{*}{$\alpha=0.4$} & \multirow{2}{*}{$\begin{array}{l}\text { Average Real } \\
\text { Growth }\end{array}$} & \multicolumn{3}{|c|}{ Contribution of } \\
\hline & & Capital & Labor & TFP \\
\hline $1975-1979$ & 2.39 & 1.32 & 1.18 & -0.22 \\
\hline $1980-1984$ & 1.52 & 0.56 & 1.26 & -0.31 \\
\hline 1985-1989 & 4.24 & 2.06 & 1.50 & 0.66 \\
\hline 1990-1994 & 3.77 & 1.59 & 3.03 & -0.87 \\
\hline 1995-1999 & 4.69 & 1.80 & 1.83 & 1.05 \\
\hline $2000-2004$ & 2.75 & 0.84 & 2.13 & -0.22 \\
\hline
\end{tabular}

20. The most important point that emerges from Table I.5 is that the contribution to growth from TFP has dropped considerably over the past five years: from a positive contribution of 1.1 percentage points in 1995-99 to a negative contribution of -0.4 percentage point in 2000-04..$^{5}$ During 1995-99, Guinea managed to reduce annual inflation from two digits to below 5 percent. In the same period, the fiscal deficit was reduced from above 5 percent of GDP, on average, to about 3 percent of GDP, and the terms of trade were improving. In contrast, between 2000 and 2004, inflation increased, the fiscal position deteriorated, and the country was exposed to numerous exogenous shocks. Because TFP captures how the overall macroeconomic environment affects productivity and growth, the results of Table I.5 indicate that a combination of exogenous shocks and changes in the policy environment has weakened growth since 2000. The next section discusses how the shocks and policy change affected growth.

\section{Growth, Exogenous Shocks, and Policy Changes}

21. As mentioned in the previous section, the Guinean economy has been exposed since 2000 to both exogenous shocks and a significant change in the stance of macroeconomic policy. Specifically, it can be hypothesized that three exogenous factors contributed the most to the slowdown in real GDP growth occurred since 2000: (i) insecurity in the region; (ii) a fall in the price of bauxite, Guinea's main export commodity; and (iii) a sharp increase in the price of imported goods, in particular petroleum products. In addition, between 2000 and 2004,

\footnotetext{
${ }^{5}$ We obtained a qualitatively (but not quantitatively) similar result from using a different value for the coefficient $\alpha$, specifically, a more common 0.4 instead of the estimated 0.3 . With this modification, TFP contributed to 1.05 percentage points of average annual GDP growth in the period 1995-99, and -0.22 a year after 2000 .
} 
macroeconomic policies were relaxed, as fiscal policy was loosened and monetary policy became highly accommodative.

\section{Growth and regional instability}

22. To study the relationship between growth and regional insecurity we used the index of political stability elaborated by Daniel Kaufman of the World Bank. This index measures the likelihood of violent threats to, or changes in, government. We used data for Cote d'Ivoire, Sierra Leone, and Liberia for 1996-2004 (the period for which data is available) and, for each year, we took the average as a proxy of regional instability.

23. The deterioration in regional security has affected growth negatively for the past five years (see Figures I.6). The left-hand panel of Figure I.6 compares growth since 1996 with the regional instability index. Beginning in 1996, the index declines and, at the same time, growth is on an increasing trend. In 1998, regional security deteriorated and growth started to decline. In 2000, the security situation worsened even more and growth dropped and became less stable. The right-hand panel of Figure I.6 presents the relationship between growth and regional insecurity. Growth is measured on the vertical axis, insecurity on the horizontal axis. This scatter plot clearly reveals the existence of a negative and strong relationship between growth and regional insecurity.

Figure I.6. Regional Instability and GDP Growth in Guinea, 1996 - 2004
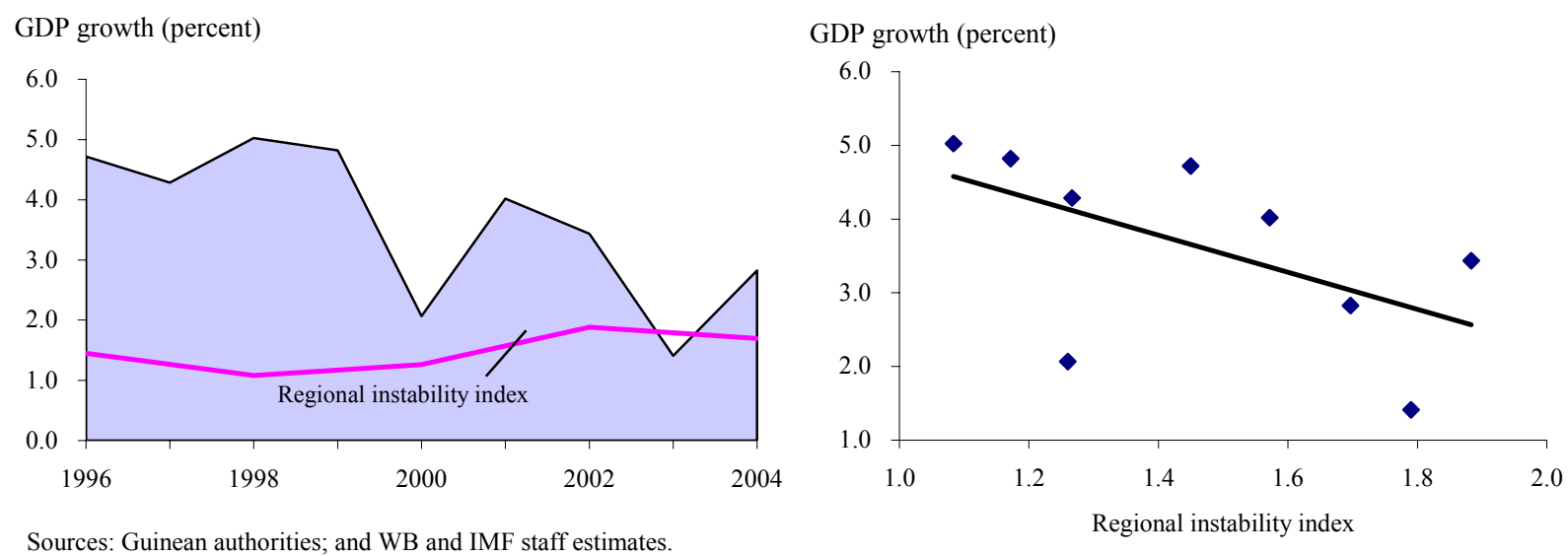

\section{Growth and the terms of trade}

24. Guinea's terms of trade have been volatile since 1992. Whereas import prices have fluctuated around a constant trend for the past 15 years, export prices and the price of bauxite in particular seem to have fluctuated around a decreasing trend. This is reflected in significant fluctuations of the terms of trade (see Figure I.7). 
Figure I.7. Guinea: Terms of Trade and GDP Growth, 1992-2004

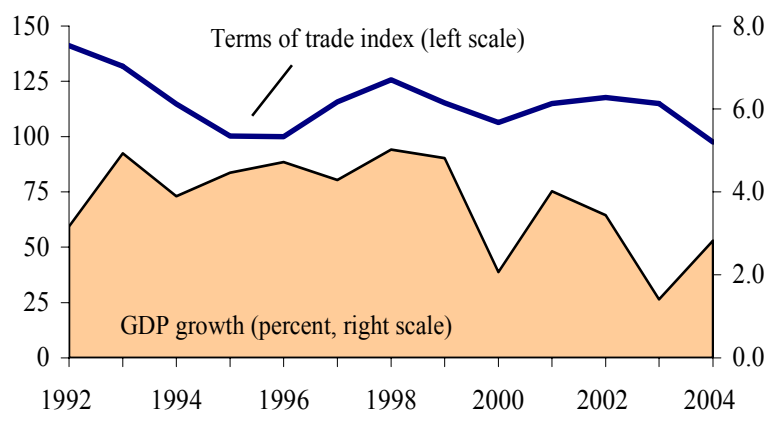

Sources: Guinean authorities; and IMF staff estimates.

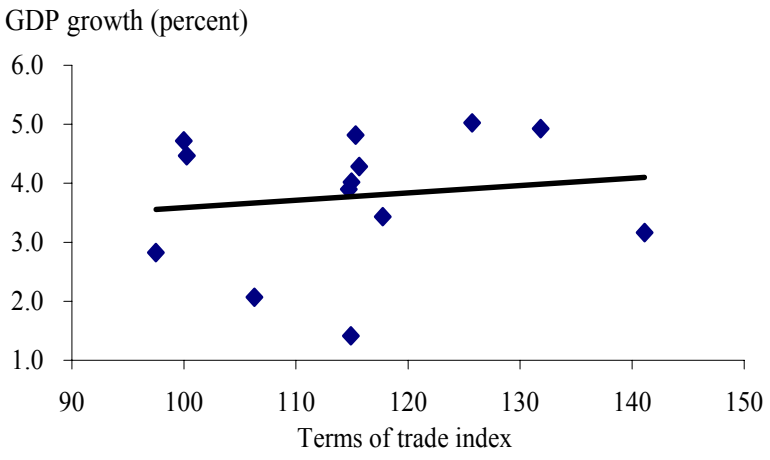

25. The terms of trade cannot robustly be imputable for the recent decline in growth. As left-hand panel of Figure 7 shows, during the past 13 years growth has been strong even when the terms of trade were deteriorating (that is, between 1992 and 1995 and in 1999). Specifically, as right-hand panel of Figure 7 shows, there is no strong relationship between growth and the terms of trade. Therefore, changes in the terms of trade cannot be robustly imputable for the slowdown in growth that started in 2000.

\section{Growth and policy changes}

26. Beginning in 2000, the stance of economic policy in Guinea was relaxed. Whereas the fiscal deficit on a cash basis averaged 3.2 percent of GDP during 1995-99, this figure increased to 4.8 percent during 2000-04. As a result, as shown in the previous section and consistent with standard macroeconomic frameworks, overall investment started to decrease and consumption to increase. At the same time, whereas Guinea managed to bring inflation down from doubledigit levels at the beginning of the 1990s to as low as 2 percent in 1997, after 2000 the monetization of the deficit caused an increase in inflation. As a result, annual CPI inflation was 4 percent, on average, during the 1990s and 10 percent, on average, during 2000-04. Along with a rise of inflation, a deterioration in the exchange rate followed.

27. Growth in Guinea had been negatively affected by the high levels of the fiscal deficit. The left-hand panel of Figure 8 displays the series of growth and the deficit as percent of GDP. The figure shows that when the fiscal deficit was below 4 percent of GDP, growth was strong. After 2000, the fiscal deficit climbed to more than 5 percent of GDP and growth contracted. The right-hand panel of Figure 8 clearly shows that there exists a strong and negative relationship between growth and the fiscal deficit. 
Figure I.8. Guinea: GDP Growth and Fiscal Deficit, 1992-2004

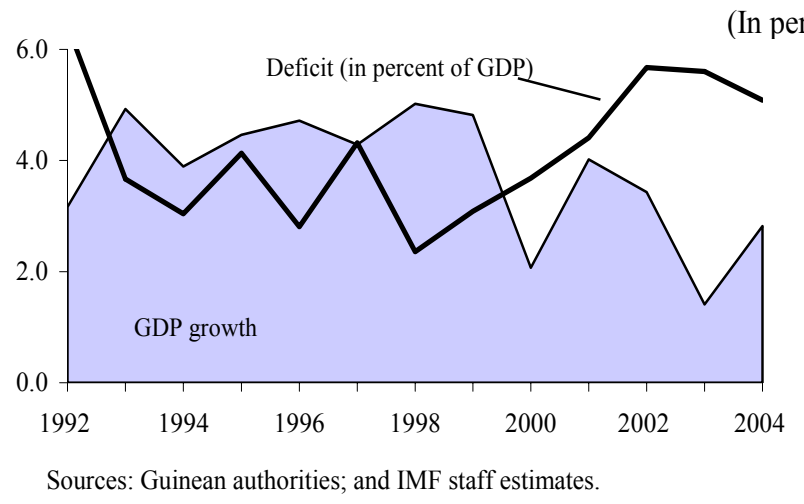

(In percent)

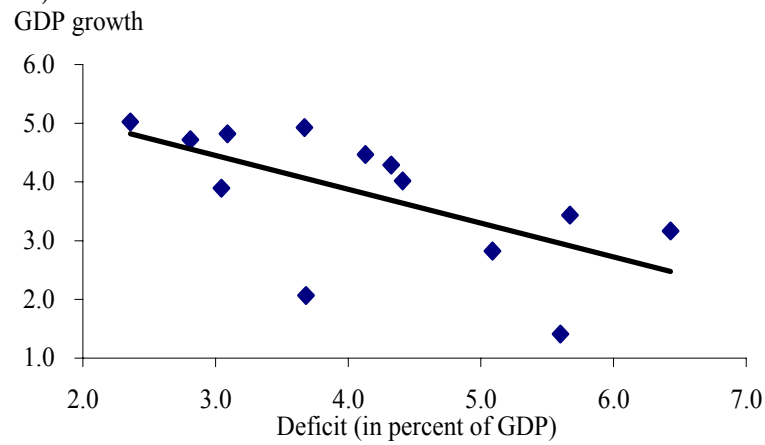

\section{Growth, exogenous shocks, and policy: regression analysis}

28. To assess the impact of policy changes and exogenous shocks on growth we used the fiscal deficit as a proxy for the stance of macroeconomic policy, and changes in the terms of trade as a proxy for exogenous shocks. ${ }^{6}$ We then regressed growth over the fiscal deficit and the changes in the terms of trade

$$
\Delta y_{t}=c+\alpha g_{t}+\beta \Delta T T_{t}+\varepsilon_{t} .
$$

In equation (7), $\Delta y_{t}$ is the rate of growth of GDP at constant 2000 prices (expressed by the difference of the natural logarithm of real GDP), $g_{t}$ is the fiscal deficit as a percentage of GDP, and $\Delta T T_{t}$ is the rate of change in the terms of trade (expressed by the difference of the natural logarithm of the terms of trade). The last term, $\varepsilon_{t}$, is an error that captures the effect of all the variables not included in the regression; assumptions on $\varepsilon_{t}$ are standard. We estimated equation (7) with data for the period 1980 to 2000, before policies changed and exogenous shocks hit the economy (see Table I.1).

29. The estimated relationship between growth, the deficit, and changes in the terms of trade is

$$
\Delta y=-0.02-0.4 g-0.02 \Delta T T+\varepsilon .
$$

The regression results and the details reported in Table I.6 suggest that, during 1980-04, there was a statistically significant and negative relationship between the fiscal deficit, our proxy for the stance of macroeconomic policy, and real GDP growth. According to these findings, the increase in the average fiscal deficit since 2000 (from 3.3 to 4.8 percent of GDP) might have reduced average annual GDP growth by 0.6 percentage point. The results instead suggest that, in

\footnotetext{
${ }^{6}$ We did not include the index of instability in the region because there are not enough observations to ensure significant estimates.
} 
the same period, changes in the terms of trade (our proxy for exogenous shocks) did not have any significant effect from real GDP growth.

Table I.6. Guinea: Growth, Deficit, and Changes in the Terms of Trade

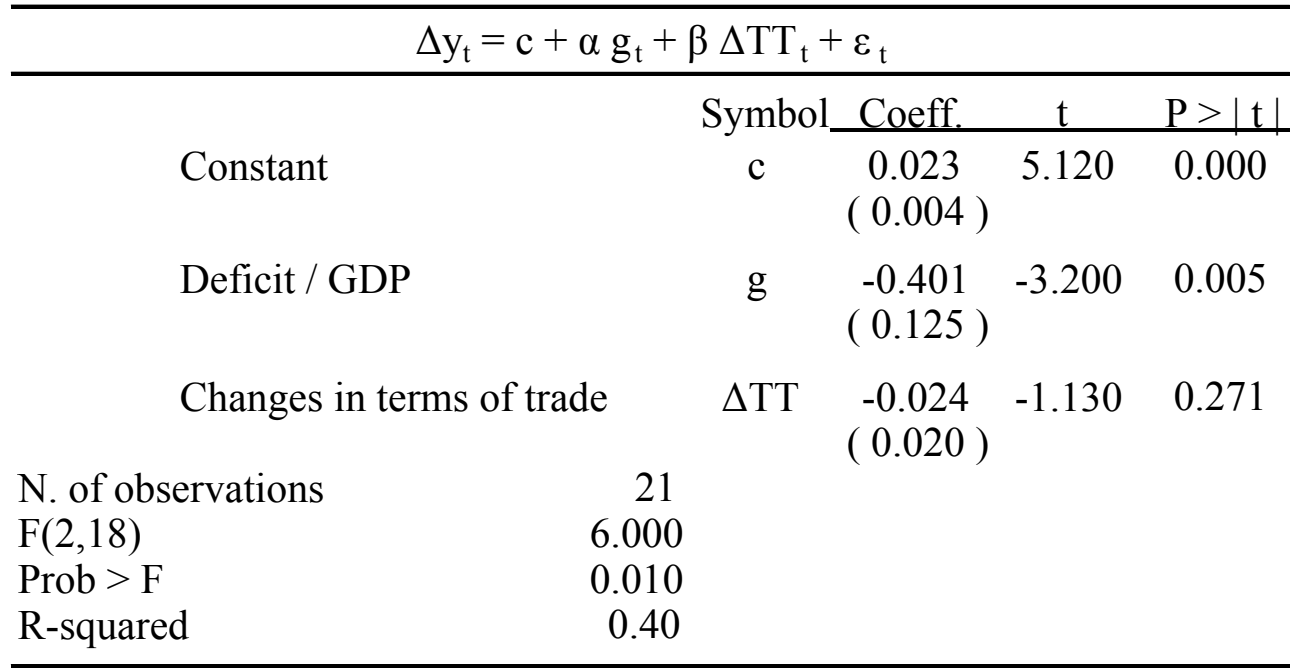

Note: Sources of data are given in Table 1.

\section{E. Conclusion}

30. After recording strong and stable growth in the 1990s, Guinea's economy has grown at a slower and less stable pace over the past five years. This slowdown came at a time when policy changes and exogenous shocks - such as a decrease in the price of bauxite and increasing regional insecurity-significantly altered the macroeconomic environment. The paper argues that these factors negatively affected growth in the last five years. Indeed, a growth accounting analysis suggests that changes in the macroeconomic environment subtracted 0.4 percentage point to annual real GDP growth.

31. The paper also argues that the Guinean economy was weakened primarily by changes in the stance of macroeconomic policies. The impact on real GDP growth of exogenous shocks is difficult to quantify. Indeed, factual and empirical analysis suggests that whereas shocks to the terms of trade has had limited impact on growth, growth is negatively correlated to both regional insecurity and policy variables such as the fiscal deficit to a significant degree. In particular, using the fiscal deficit as a proxy for policy, there is evidence that inappropriate macroeconomic policies might have been responsible, since 2000, for a decrease in the real rate of growth of 0.6 percentage points. 


\section{References}

Barro, Robert and Xavier J. Sala-i-Martin, 1995, Economic Growth, New York: Mc GrawHill.

Akitoby, Bernardin and Matthias Cinyabuguma, 2004, "Sources of Growth in the Democratic Republic of the Congo: A Cointegration Approach," IMF Working Paper No. 04/114, Washington: International Monetary Fund.

Nsegiyumva, Fabien, 2003, "Source of Economic Growth in Benin," Benin: Selected Issues and Statistical Appendix, Washington: International Monetary Fund.

Senhadji, Abdelhak, 2000, " Sources of Economic Growth: An Extensive Growth Accounting Exercise,” IMF Staff Papers, Vol. 47 No. 1, pp. 129-57.

Tahari, Amore, Dhaneshwar Ghura, Bernardin Akitoby and Emmanuel Brou Aka, 2004, "Sources of Growth in Sub-Saharan Africa," IMF Working Paper No. 04/176, Washington: International Monetary Fund 


\section{BANKING SECTOR DEVElopMents In GUINEA ${ }^{7}$}

\section{A. Introduction}

32. This paper examines the main challenges facing Guinea's banking system resulting from recent economic and policy developments and banks' response to them. In particular, it considers how the banking system has responded to the unification and liberalization of the foreign exchange market, accelerating inflation, and rising dollarization of the economy. Although the paper finds that the banking system has adapted to the changes, more needs to be done if banks are to remain sound and profitable over the medium term. The sector's profitability rests on the availability of low-interest deposits, which are either demand or short-term savings deposits. But with the liberalization of the foreign exchange market and continued dollarization of the economy, the supply of deposits may dry up. The paper recommends liberalizing the interest rate structure and raising policy rates to maintain the attractiveness of instruments denominated in the national currency. It also contemplates further reforms of the foreign exchange market centered on promoting transparency and price competition among market participants. Finally, the paper suggests stronger enforcement of prudential rules to limit the risks of systemic failure associated with banks' excessive exposure to a few prominent clients.

33. The paper is organized as follows. Section B presents an overview of the financial sector. Section C discusses the banking sector's response to the liberalization of the foreign exchange market. Section D considers the impact of dollarization on the banking system and analyzes possible consequences for interest rate policy. The paper concludes with a summary of key findings and policy recommendations.

\section{B. Overview of the Banking Sector and Financial Markets}

\section{Overview of the banking sector}

34. Guinea's banking sector is relatively small and highly concentrated, and is dominated by foreign capital. It consists of seven banks, all of which are majority or wholly foreign owned, with total assets equivalent to about 13 percent of GDP. About 75 percent of total bank assets are concentrated in the three largest banks. The government holds a 40 percent stake in a small bank

\footnotetext{
${ }^{7}$ Prepared by Michael Gorbanyov.
}

Figure II.1. Concentration of Assets, Mid-2005 (Share of total assets of the banking system in selected number of top banks)

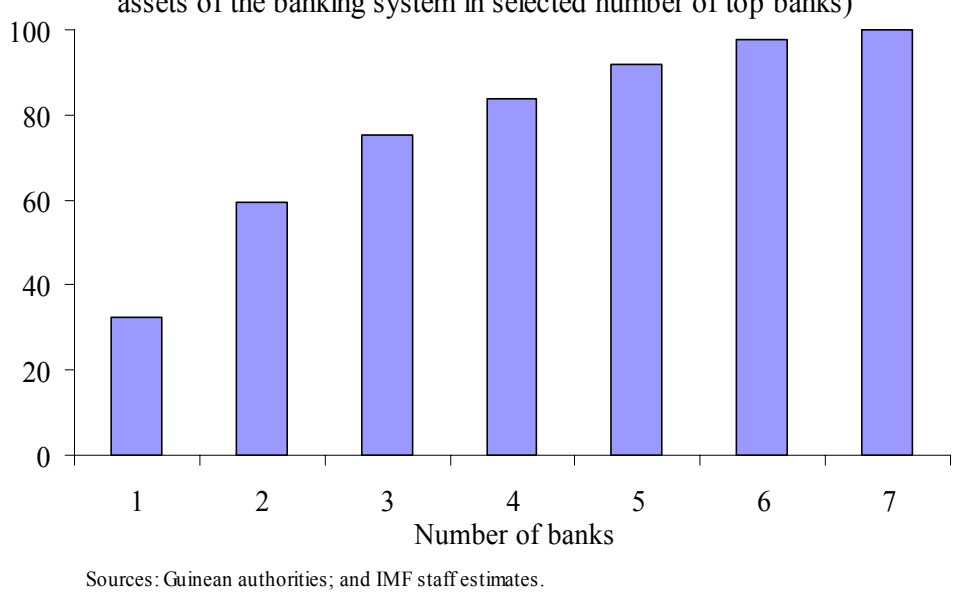


and has recently privatized a part of its stake in the largest bank, reducing its share in that bank's capital from 38 percent to less than 20 percent. Banking sector penetration remains low, and only about 2 percent of Guineans have a bank account.

35. The banking sector is supplemented by a growing network of microfinance institutions (MFIs). MFIs provide financial services to households and small and medium businesses, mostly those who lack access to financial products from banks. In the past several years, the MFI expansion in Guinea has outpaced the rate of growth of the banking sector. ${ }^{8}$ As of end-2004, there were 10 MFIs in Guinea, with over 300 local offices and more than 180,000 clients.

36. As the economy's demand for banking credit has declined, the banks increased credit to the government and accumulated foreign assets. The share of gross credit to the private sector in the banking system's assets has declined from nearly 40 percent at end-2001 to 23 percent at mid2005. Even with lending rates staying below inflation, the demand for credit in the economy is low, and regular account overdrafts represent about 65 percent of total lending to private sector customers. On a net basis,

\begin{tabular}{|c|c|c|c|c|}
\hline \multicolumn{5}{|c|}{ Table II.1. Banking System Structure, Mid-2005 } \\
\hline & \multirow[b]{2}{*}{$\begin{array}{l}\text { Number of } \\
\text { Institutions }\end{array}$} & \multicolumn{3}{|c|}{ Financial Sector Assets } \\
\hline & & $\begin{array}{c}\text { (In } \\
\text { billions of } \\
\text { GNF) } \\
\end{array}$ & $\begin{array}{c}\text { (Percent of } \\
\text { banking } \\
\text { system) } \\
\end{array}$ & $\begin{array}{l}\text { (Percent } \\
\text { of GDP) }\end{array}$ \\
\hline Commercial banks & 7 & 1581.6 & 98.6 & 13.2 \\
\hline Large foreign-owned & 3 & 1188.9 & 74.1 & 10.0 \\
\hline Other foreign-owned & 4 & 392.7 & 24.5 & 3.3 \\
\hline Microfinance institutions (MFIs) 1/ & 10 & 23.0 & 1.4 & 0.2 \\
\hline Total banking sector and MFI 2/ & 17 & 1604.6 & 100.0 & 13.4 \\
\hline
\end{tabular}

Table II.2. Selected Indicators of Microfinance Institutions, 2002-04 1/

\begin{tabular}{|lrrr|}
\hline & 2002 & 2003 & 20042 \\
\hline Number of branches & 120 & 127 & 135 \\
Beneficiaries (thousands of clients) & 139.8 & 160.2 & 161.9 \\
Deposits (in billions of GNF) & 6.8 & 8.9 & 12.3 \\
Loans (in billions of GNF) & 16.7 & 19.1 & 23.0 \\
$\quad$ Of which: nonperforming loans (in & & & \\
percent of total loans) & 2 & 5 & 10 \\
Lending interest rate (average, in percent) & 26 & 30 & 28 \\
\hline Source: Central Bank of Guinea. & & & \\
1/ Aggegate figures for the four largest institutions. & & \\
2/ Data for end-January 2005. & & & \\
\hline
\end{tabular}

Figure II.2. Banks' Assets and Liabilities, 2002-05

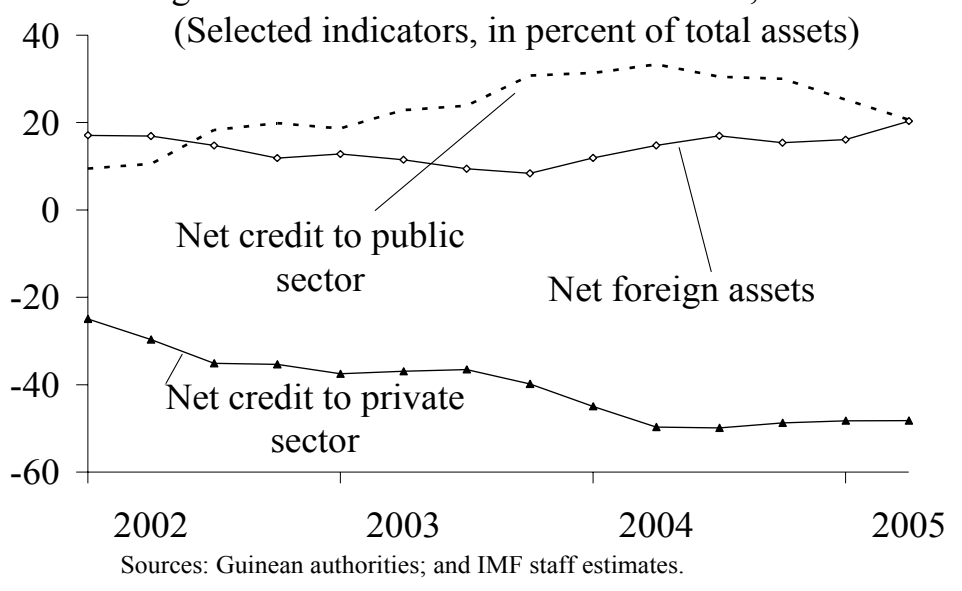
the private sector is a bulk creditor to commercial banks, with its net credit having grown to as much as 50 percent of the

${ }^{8}$ The factors explaining MFI development in Guinea and in other African countries are discussed in Basu et al., 2004; for a broader perspective on MFIs, see Hardy et al., 2002. 
banks' total assets. The banks reallocate the funds raised from the private sector to credit to the government and to net foreign assets. The open foreign exchange position of the banking system has increased from less than 8 percent of capital at end-2002 to more than 19 percent by mid-2005.

Table II.3. Guinea: Financial Soundness Indicators of the Banking Sector, 2002-June 2005 (In percent, unless otherwise indicated)

\begin{tabular}{|c|c|c|c|c|c|}
\hline & Prudential Limits & 2002 & 2003 & 2004 & June 2005 \\
\hline \multicolumn{6}{|l|}{ Capital adequacy } \\
\hline Net capital (GNF billion) 1/ & GNF 5 billion $2 /$ & 9.2 & 8.7 & 10.8 & 14.6 \\
\hline Regulatory capital to risk-weighted assets $1 /$ & $10 \% \quad 3 /$ & 18.4 & 15.8 & 12.2 & 12.7 \\
\hline Loans larger than 15 percent of capital to regulatory & Eight times & & & & \\
\hline capital (ratio) $1 /$ & capital & 1.4 & 1.8 & 1.7 & 2.9 \\
\hline Number of loans larger than 25 percent of capital $1 /$ & 0 & 2.1 & 2.6 & 1.3 & 2.1 \\
\hline $\begin{array}{l}\text { Loans to managers and insiders to regulatory capital } 1 / \\
\text { Number of loans to managers and insiders larger }\end{array}$ & $10 \%$ & 11.3 & 9.3 & 7.7 & 6.5 \\
\hline than 5 percent of capital $1 /$ & 0 & 0.6 & 0.6 & 0.3 & 0.7 \\
\hline \multicolumn{6}{|l|}{ Liquidity and foreign exchange position } \\
\hline Liquid assets to short-term liabilities $1 /$ & $100 \% 4 /$ & 363.6 & 172.8 & 214.8 & 175.4 \\
\hline \multirow[t]{2}{*}{ Open foreign exchange position to regulatory capital $1 /$} & $35 \%$ & 7.7 & 11.0 & 17.2 & 19.3 \\
\hline & \multicolumn{5}{|c|}{$\begin{array}{l}\text { (Number of banks respecting the prudential limits, out of } \\
\text { a total of seven banks) }\end{array}$} \\
\hline Net capital (GNF billion) & GNF 5 billion 2/ & 5 & 6 & 6 & \\
\hline Regulatory capital to risk-weighted assets & $10 \% \quad 3 /$ & 7 & 7 & 7 & \\
\hline $\begin{array}{l}\text { Loans larger than } 15 \text { percent of capital to regulatory } \\
\text { capital (ratio) }\end{array}$ & $\begin{array}{l}\text { Eight times } \\
\text { capital }\end{array}$ & 7 & 7 & 7 & \\
\hline Number of loans larger than 25 percent of capital & 0 & 3 & 5 & 2 & \\
\hline Loans to managers and insiders to regulatory capital & $10 \%$ & 4 & 4 & 5 & \\
\hline Number of loans to managers and insiders larger & & & & & \\
\hline than 5 percent of capital & 0 & 4 & 4 & 6 & \\
\hline Liquid assets to short-term liabilities & $100 \% 4 /$ & 7 & 7 & 7 & \\
\hline Open foreign exchange position & $35 \%$ & 7 & 7 & 6 & \\
\hline
\end{tabular}

Source: Central Bank of Guinea (BCRG).

$1 /$ Included in the prudential regulation of the BCRG. Presented as average of seven banks.

2/ The minimum regulatory net capital was GNF 2 billion before March 2002.

3 / The ratio was 8 percent before June 2003 .

4/ The ratio was 70 percent before June 2003.

37. The primary concerns in the area of banking supervision are compliance with regulations for risk concentration and capital adequacy. Several banks regularly exceed prudential limits for risk concentration and allocate the bulk of credit to their largest customers, in particular to petroleum-importing companies that have access to revolving credit lines. As of mid-2005, four of Guinea's seven banks have provided loans exceeding 
25 percent of their net capital to prominent clients, and two banks have extended five such loans each. Given the economic slowdown, weak judicial system, and high transaction costs, banks need to develop close ties with borrowers to insure their readiness to repay credit. This strategy seems to bear fruit: the share of nonperforming loans (NPLs) in total loans to the private sector declined to 22 percent by mid-2005 from more than 30 percent in 2003 , with provisions covering 97.5 percent of NPLs. Although close ties between banks and their largest borrowers help reduce transaction costs, they also raise the risks of systemic failure because banks' soundness becomes critically dependent on these clients' solvency. Bank recapitalization can

\begin{tabular}{|lrrrr|}
\hline \multicolumn{5}{|c|}{ Table II.4. Structure of Credit Portfolio of the Commercial Banks, } \\
& 2002 - June 2005 & & \\
& 2002 & 2003 & 2004 & June-05 \\
\hline & (In billions of Guinean francs) \\
1. Total credit outstanding & 310.7 & 368.7 & 381.3 & 468.8 \\
2. Performing credits & 225.5 & 259.7 & 276.8 & 365.3 \\
Of which: nonimputed values (NIVs) & 6.3 & 7.0 & 0.2 & 0.2 \\
3. Frozen credits & 5.3 & 5.8 & 4.5 & 1.1 \\
4. Doubtful and contentious loans net & 9.2 & 16.9 & 2.0 & 2.6 \\
5. Provisions & 70.7 & 86.4 & 98.0 & 99.8 \\
6. Nonperforming loans (NPLs) (4+5) & 79.9 & 103.2 & 100.0 & 102.4 \\
7. Unpaid loans (NIVs+3+4+5) & 91.5 & 116.0 & 104.7 & 103.7 \\
& & $($ In percent) & \\
Unpaid loans to total loans & 29.4 & 31.5 & 27.5 & 22.1 \\
NPLs to total loans & 25.7 & 28.0 & 26.2 & 21.8 \\
Coverage of NPLs & 88.5 & 83.7 & 98.0 & 97.5 \\
\hline Source: Central Bank of Guinea. & \multicolumn{5}{c}{} \\
\hline
\end{tabular}
help improve risk concentration ratios, and the recent recapitalization of one of the banks demonstrates that such a solution can be feasible. The issue of capital adequacy had become even more relevant by mid-2005, when the net capital of two banks dropped to less than 10 percent of their risk-weighted assets, the limit set by the banking regulation.

38. The authorities are taking steps to improve the legal framework for banking business and supervision, but further change in judicial practices is needed. Development of the banking sector has been hampered by the weakness of the legal system, which makes it difficult to protect contracts and recover nonperforming loans. The new banking law, adopted in July 2005, is expected to strengthen the legal framework. The draft of the new law on MFIs, which has been submitted to the National Assembly, will extend banking supervision to cover MFIs as well. The authorities are finalizing a draft of a new law to step up measures to combat money laundering and the financing of terrorism. ${ }^{9}$

\section{Development of domestic financial markets}

39. The financial market in Guinea generally lacks depth and would benefit from further development of basic infrastructure and regulations. Only in the foreign exchange and government securities markets are the volumes of operation substantial. There are no domestic markets for corporate bonds or securities. In March 2005, the authorities began taking steps to unify the foreign exchange market and to move from dual exchange rates to a unified market-determined exchange rate.

\footnotetext{
${ }^{9}$ MFD provided extensive comments on an early draft of the law.
} 


\section{Box II.1. Preconditions for a Successful Liberalization of Foreign Exchange Market}

Monetary authorities should address several key issues for a successful move to a more flexible exchange rate regime in the context of foreign exchange market liberalization (Duttagupta, Fernandez, and Karacadag, 2004):

- $\quad$ develop a deep and liquid foreign exchange market

- formulate intervention policies consistent with the new exchange rate regime

- $\quad$ establish an alternative nominal anchor in the context of a new monetary policy framework

- $\quad$ build the capacity of market participants to manage exchange rate risks and of the supervisory authorities to regulate and monitor them

In particular, the following steps can increase the depth and efficiency of the foreign exchange market in the process of moving toward more flexible arrangement:

- $\quad$ allowing some exchange rate flexibility within the preexisting arrangement

- $\quad$ reducing the central bank's market-making role, and increasing market information

- $\quad$ eliminating (or phasing out) regulations that stifle market activity

- $\quad$ unifying and simplifying foreign exchange legislation

- $\quad$ facilitating the development of risk-hedging instruments

In Guinea, the need to eliminate macroeconomic imbalances meant that the authorities had to move to a more flexible exchange arrangement before they could adequately address these key issues. As a result, both the monetary authorities and market participants have had to adapt to the changes as they have occurred rather than prepare for them in advance.

40. The authorities have made strong progress in reforming the foreign exchange market. In March 2005, the central bank abandoned the system of rationing foreign exchange for critical imports through official auctions and took the first steps to unify and liberalize the foreign exchange market. Furthermore, the authorities are implementing technical measures to strengthen the functioning of the foreign exchange market, encourage dissemination of market information, and improve the central bank's capacity to monitor and influence market developments. Following the introduction of the new foreign exchange market setup, the Guinean franc has depreciated rapidly. At the same time, the gap between the central bank's reference exchange rate and the exchange rate of exchange bureaus shrank to less than 2 percent by October 2005, as compared to the spread between official and free market rates of 25-30 percent in 2004 and early 2005. The central bank has normalized settlements with banks and reduced the backlog in banks' foreign exchange transfers abroad to US\$2.5 million by end-September from about US\$18.5 million at the onset of market unification. ${ }^{10}$ However, the central bank has still not defined a policy to guide its interventions in the foreign exchange market and is upgrading capacities for performing open market operations. ${ }^{11}$

\footnotetext{
${ }^{10}$ The central bank has a monopoly on performing settlements between the local and international commercial banks and, in particular, on transferring foreign exchange from local banks abroad.

11 The authorities are implementing the recommendations of MFD technical assistance missions with regard to foreign exchange market development and capacity building in the central bank.
} 
Figure II.3. Guinea: Exchange Rates Before and After the Market Unification Reform

(Guinean francs per U.S. dollar, unless otherwise indicated)

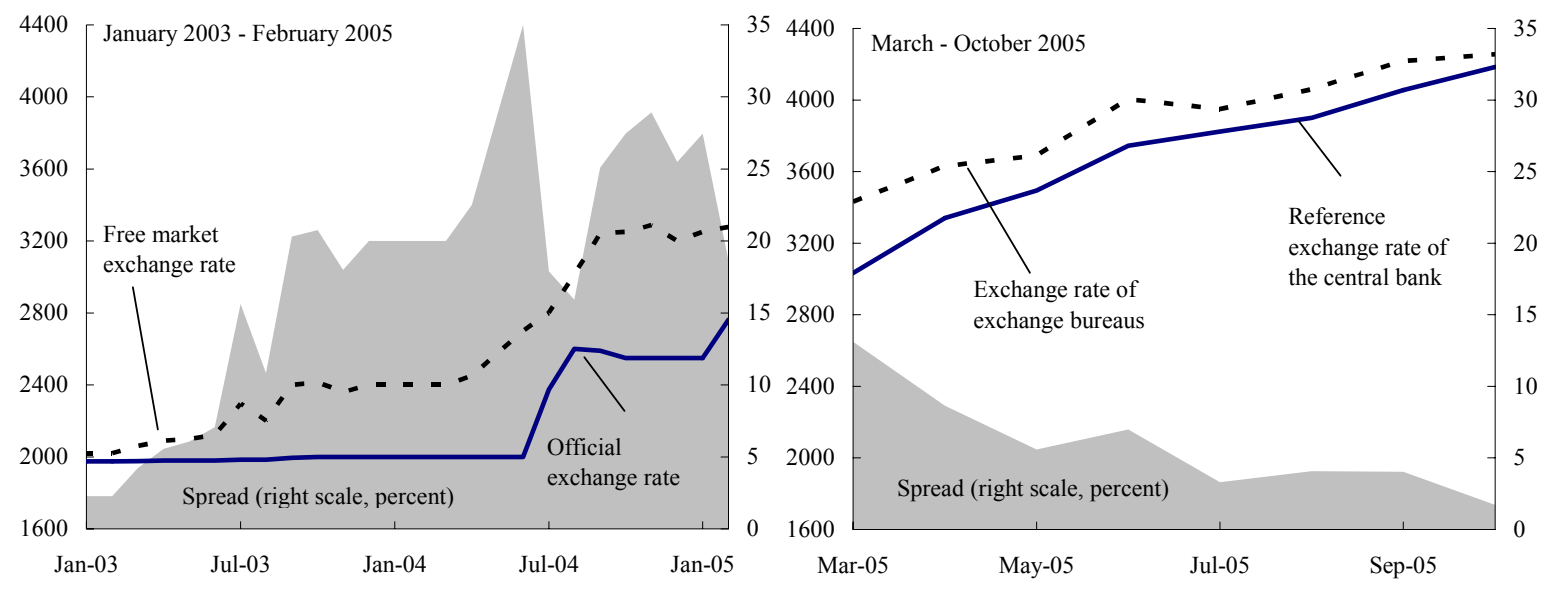

Source: Central Bank of Guinea.

41. Despite the ongoing market reform, some foreign exchange transactions are still conducted outside the banking system. The banks perform foreign exchange operations mainly with their regular clients, buying foreign exchange from exporters and selling it primarily for critical imports. ${ }^{12}$ As the interbank market is virtually nonexistent for foreign exchange, the banks have few other sources of it but the supply that comes from their clients. ${ }^{13}$ Outside the banking sector, there are 86 authorized exchange bureaus and an unknown number of informal traders that can promptly perform conversion operations. There is no official statistics for the foreign exchange turnover, even for the operations performed by the banks.

\footnotetext{
${ }^{12}$ According to an agreement with petroleum-importing companies, the three largest banks mobilize foreign exchange for oil imports. The banks operate in turn, so that each month one bank sells to importers the amount of foreign exchange they need.

${ }^{13}$ This situation implies that a bank cannot quickly mobilize large amounts of foreign exchange if the need arises. Therefore, the banks have to maintain large foreign exchange balances on their operating accounts and control open foreign exchange positions so that an unexpected temporary shortage of foreign exchange would not affect their liquidity and solvency.
} 
42. The authorities are gradually improving procedures for placing government securities. The government finances the budget deficit by placing treasury bonds (BDT) with maturities ranging from four weeks to six months. The central bank uses two-week notes (TRM) to sterilize excess liquidity in the banking system and manage reserve money growth. Commercial banks are the principal buyers and holders of government and central bank securities. There are no secondary market or repurchase operations with these securities. The interest rates on the government securities remain sticky: they do not respond promptly to changes in market conditions. As of October 2005, the average TRM interest rate was 19 percent, and the interest rates on BDT were 19-20 percent depending on maturity, resulting in negative real interest as 12-month

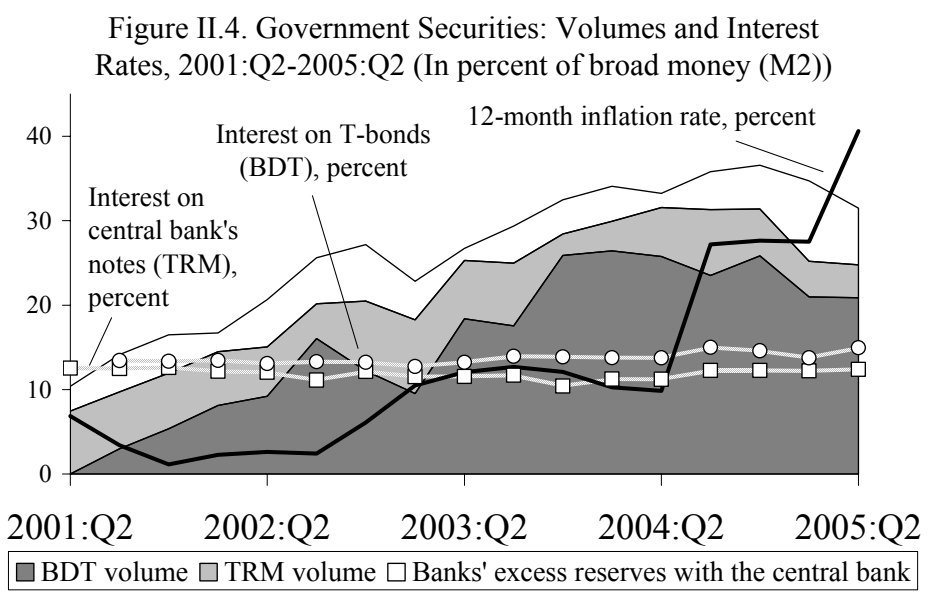

Sources: Guinean authorities; and IMF staff estimates. inflation was running as high as 28 percent. The amount of BDT and TRM outstanding totaled about 4 percent of GDP. ${ }^{14}$

\section{Banks in the Foreign Exchange Market}

\section{Competition with exchange bureaus and informal traders}

43. Although price competition dominates the nonbank market for foreign exchange, the banking sector, which centers on building long-term relationships with valuable clients, remains less competitive. Nonbank operators post competitive quotes to attract clients; the clients react quickly to quote changes, and the resulting average exchange rate broadly reflects the interaction of supply and demand. On the contrary, competition among banks is subdued, and foreign exchange conversion operations represent, for them, only a small part of the overall package of services they offer their clients. A client, attracted by the overall package, chooses a bank and stays with it as long as the package remains satisfactory, because the transaction costs of shifting all operations to another bank can be significant.

44. Banks and exchange bureaus specialize in different types of transactions and serve different groups of clients, which results in market segmentation. Commercial banks perform mainly noncash operations related to settlements with foreign countries. For their part, exchange bureaus and informal traders mainly carry out cash transactions related to trade with neighboring African countries and to the demand for foreign exchange for

\footnotetext{
${ }^{14}$ The authorities are also implementing MFD technical assistance recommendations with regard to further development of the auctioning system for government and central bank securities.
} 
domestic circulation. For many economic agents, the main benefit of using the services of exchange bureaus and informal traders is that the contracts are less formal, which helps reduce transaction costs. The main advantages of using the banking system relate to access to international settlements, which are essential for many international trade operations, and stronger legal protection of the contracts. The market outside the banking system seems to be characterized by a structural surplus of foreign exchange, whereas the banking system normally experiences a structural deficit of "scarce" foreign exchange. The supply of foreign exchange to the banks (for example, from exporters selling a part of their revenues) in the first nine months of 2005 was barely enough to cover the demand related to the banks' long-term contracts with valuable clients, including the amounts that banks need to mobilize for petroleum importers. It has been difficult for the banks to attract foreign exchange, partly because of the absence of price competition in the banking sector and partly because of institutional problems that provide a competitive advantage to exchange bureaus and informal traders. For example, the sources of currency circulating outside the banking system usually cannot be verified, which can raise money laundering issues for banks operating with this money. Therefore, the banks concentrate on providing traditional banking and settlement services to their clients, while nonbanking institutions mobilize and sell foreign exchange.

\section{Recommendations for foreign exchange market development}

45. Further reforms of the foreign exchange market should be centered on promoting transparency and price competition. The authorities should continue dismantling the formal and implicit constraints that prevent banks from bidding competitive exchange rates. In particular, they should not pressure the banking sector to finance critical imports below the market price - a practice that distorts market competition and discourages banks from reporting the actual size of operations. For their part, the banks could be more proactive in expanding their foreign exchange operations. With support from the central bank, they can begin transacting in foreign exchange with each other and with authorized exchange bureaus. Furthermore, the authorities should strive to create equal conditions for all agents operating in the market. Because Guinea's banks may be subject to stricter prudential controls than the exchange bureaus - not to mention the informal traders, who are largely not subject to control - their transaction costs are higher. In particular, the authorities can reconsider the recent regulation that limits cash withdrawals from banking accounts to the equivalent of about US $\$ 5,000$, requiring an explanation of purpose for larger withdrawals. ${ }^{15}$ The leveling of the playing field for all market participants would help promote price competition and reduce market segmentation in the domestic foreign exchange market.

\footnotetext{
${ }^{15}$ The regulation was introduced in mid-2005 to encourage noncash settlements in the economy, counter money laundering, and protect the banking system from unexpectedly large deposit outflows. The practical results have been mixed, with many bank clients complaining that the regulation imposed additional transaction costs, which discourage them from operating through the banks.
} 


\section{Dollarization of the Economy and Interest Rate Structure}

\section{Causes of increasing dollarization}

46. The dollarization of the economy has occurred in response to macroeconomic instability. Historical evidence for Guinea suggests that dollarization declined in periods of prolonged exchange rate stability, and increased sharply in periods of currency

depreciation. ${ }^{16}$ The recent increase in dollarization can be attributed to both the depreciation of the national currency and to unfavorable macroeconomic developments. When inflation is high and unpredictable and banks are offering low interest rates, converting savings into foreign exchange helps preserve their purchasing power. To reverse dollarization, the authorities need to stabilize the local currency's exchange rate, bring inflation down, and raise the interest rates on bank deposits in national currency. Although exchange rate stability would play a significant role in any program to reverse

Figure II.5. Currency Depreciation and

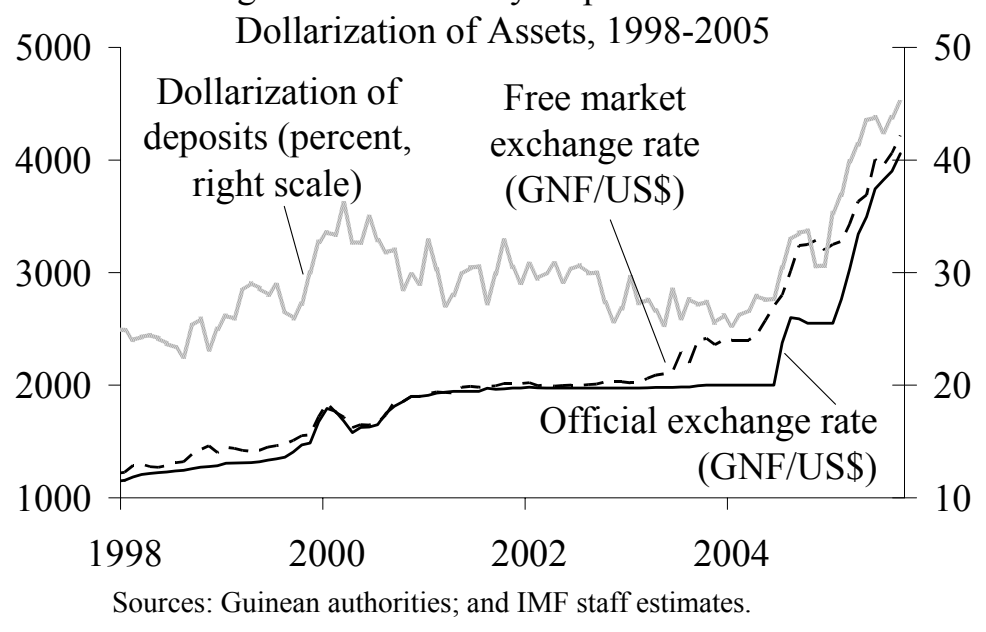

dollarization, it would be insufficient without supporting policies in place.

47. Guinea's unification and liberalization of the foreign exchange market in 2005 released the pent-up demand for foreign currency assets, which resulted in further dollarization of the economy. Liberalization of the foreign exchange market reduced the transaction costs of buying and selling foreign exchange, as well as the risks of using it as a medium of payment or of holding foreign cash savings. Despite increasing dollarization, the creation of a transparent and competitive market for foreign exchange should have a positive impact on the economy in the medium term. The reduction of excess reserves of commercial banks, elimination of a backlog in banks' foreign exchange transfers abroad, and the narrowing of spreads between foreign exchange quotes of banks and exchange bureaus to less than 2 percentage points by mid-October indicate that the pent-up demand for foreign exchange has largely been satisfied.

\footnotetext{
${ }^{16}$ The measures of asset dollarization are sensitive to changes in the value of foreign exchange deposits resulting from movements in the exchange rate of the Guinean franc.
} 


\section{Impact on the banking system's deposit and lending operations}

48. The availability of low-interest deposits is the main pillar of the banking system's profitability, which dollarization could undermine. Demand and short-term saving deposits account for up to 80 percent of liabilities of commercial banks. Demand deposits bear no interest, while the interest on savings deposits is low and remains well below inflation. The banks can attract cheap deposits mainly because of very limited competition and the lack of alternative investment opportunities in the economy. However, the increasing availability of foreign exchange for savings and transactions has created an alternative to bank deposits for both individuals and businesses. Therefore, to safeguard the deposit base, the banking system may find it necessary to raise interest rates, which would require a fundamental change to the existing system of interest rate setting and credit allocation in the economy.

Figure II.6. Guinea: Deposit and Lending Operations of the Banks, Selected Indicators,

January 2002 - September 2005

Short-Term Assets and Liabilities of Banking System

(In percent of total assets and liabilities)

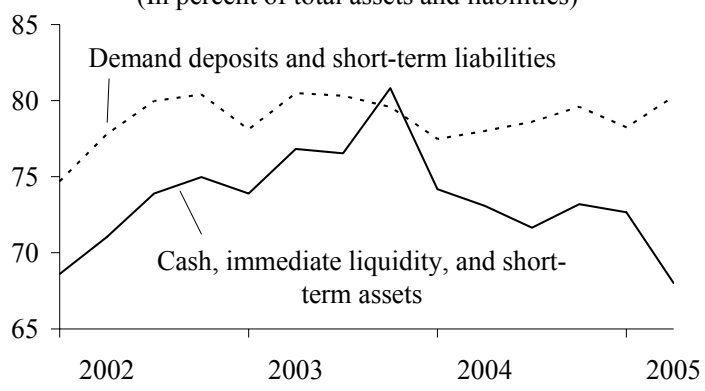

Deposits in Guinean Francs and Bank Credit to Government (In percent of broad money)

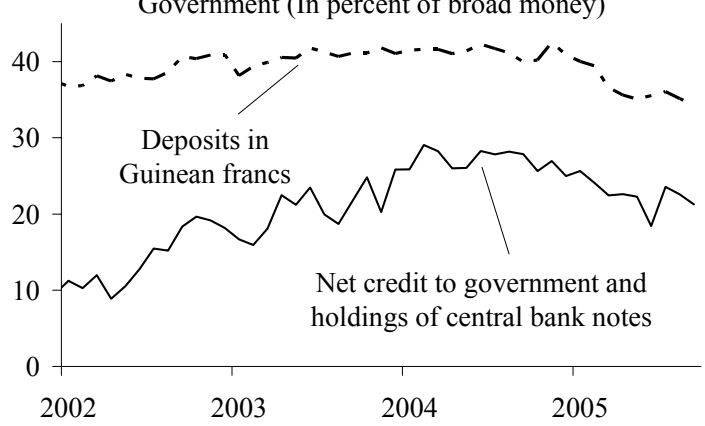

Real Interest Rates and Deposits in Guinean

$$
\text { Francs }
$$
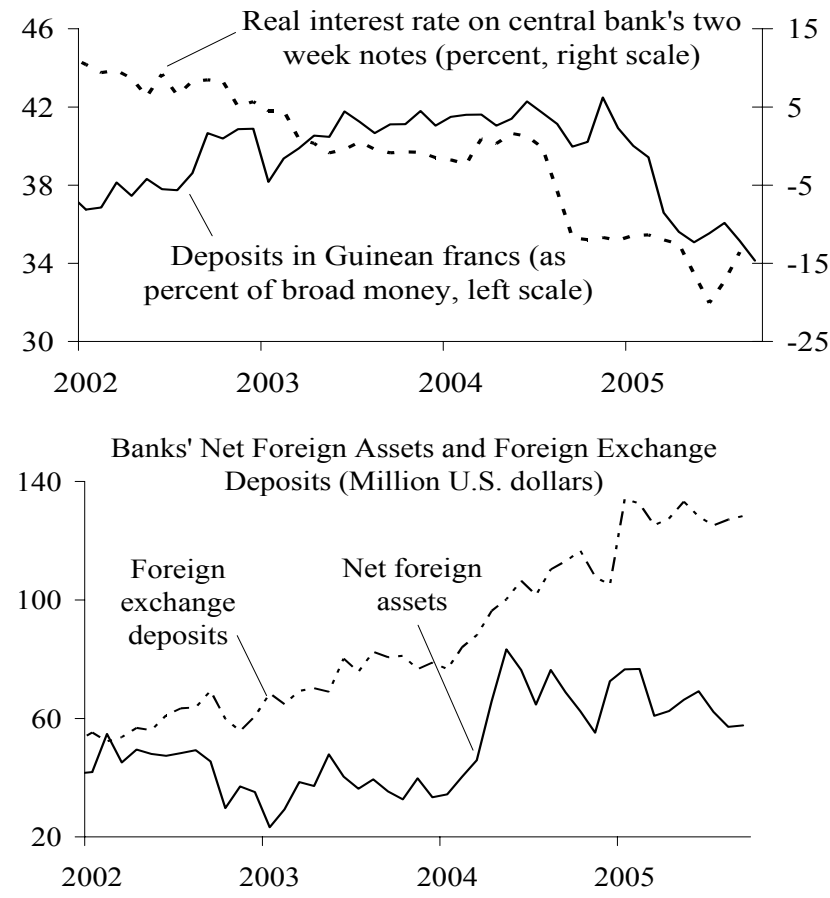

Sources: Guinean authorities; and IMF staff estimates.

49. The rising dollarization of deposits in 2004-05 prompted banks to increase their foreign asset positions and limit domestic credit. Nearly two-thirds of the funds that banks raise from local currency deposits go to the government as credit, while foreign currency deposits contribute to increases in net foreign assets. In this way, banks limit currency and maturity mismatches in their balance sheets. If the dollarization of economy continues to 
rise, the dwindling supply of local currency deposits can constrain banks' potential to extend credit to domestic companies and households.

\section{Implications for the central bank's interest rate policy}

50. Guinea's interest rate policy helps keeping the costs of financing the budget deficit low while guaranteeing banks' profitability. The central bank sets the floor for some deposit rates and the ceiling for some lending rates. At the same time, the banks bid for government and central bank securities at the rates that guarantee at least a small margin above the average costs of attracting deposits. This system allows the government to finance the budget deficit at a rate below inflation and still maintain the soundness and profitability of the commercial banks. However, it works only as long as there is a steady supply of deposits remunerated at rates well below inflation $n$ or not remunerated. The increase in the reserve requirement ratio from end-October 2005 will reduce excess liquidity in the banking system. Furthermore, as discussed above, dollarization of the economy can undermine the local deposit base of commercial banks and force them to enter into price competition for deposits, for which the banks may be not fully prepared.

51. Interest rate policy in Guinea effectively limits the use of the interest rate as a signal of the stance of monetary policy. The system is efficient in maintaining low interest rates, which, to some extent, can be viewed as reflecting the conditions of the domestic money market. However, it works only as long as there are factors other than interest rates that motivate economic agents to keep assets denominated in local currency. In particular, the central bank cannot effectively use this system to transmit monetary policy signals, influence the demand for foreign exchange, or reduce inflation pressures. For example, the

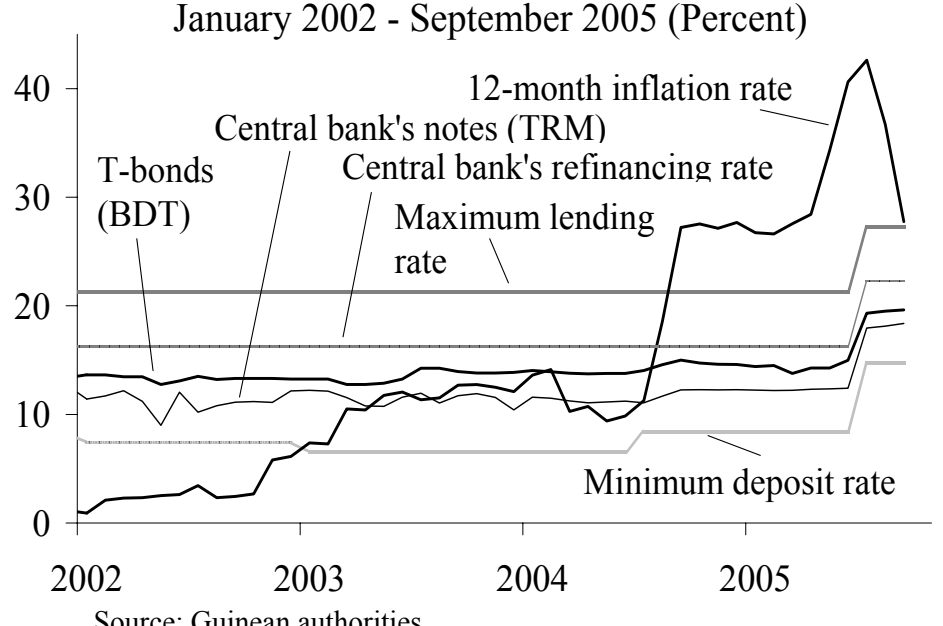

Source: Guinean authorities.

Figure II.8. Exchange and Interest Rates,

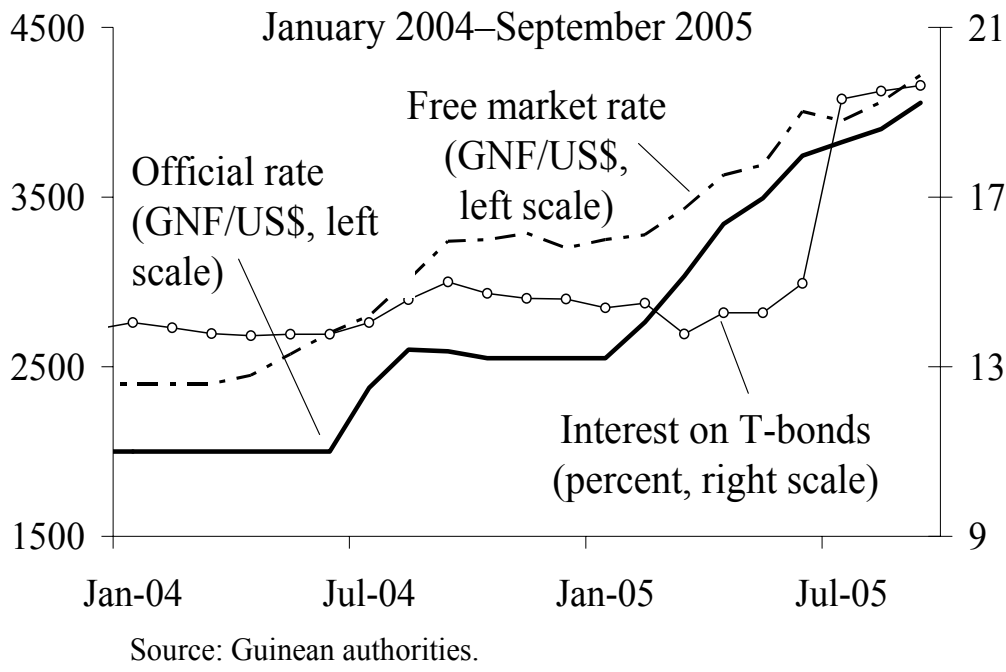


increase in the interest rate structure by as much as 6 percentage points since July 2005 has had no discernible effect on the exchange rate trend.

52. Interest rate policy should become more flexible as the barriers between domestic monetary and foreign exchange markets erode gradually. Until recently, it has been difficult to convert local currency assets into foreign exchange. To make the conversion, it was necessary for economic agents either to pay a conversion premium over the official exchange rate or to wait in line for an allocation of foreign exchange through official auction procedures. Moreover, banks had to wait many months for the central bank to transfer abroad the foreign exchange that they purchased. As a result, the interest rate for assets denominated in local currency was low, reflecting the limited opportunities for investing them. However, with the obstacles for converting local currency into foreign exchange getting lower, the interest rate might once again become an incentive to hold balances in domestic currency. Market forces should be allowed to move interest rates to levels consistent not only with the equilibrium in the domestic liquidity market, but also with a broader equilibrium in the financial markets in general, encompassing the markets for both local and foreign currency instruments. In particular, domestic short-term interest rates should normally match or exceed both the expected inflation and the expected depreciation rate of the local currency. To facilitate interest rate flexibility, the central bank should consider discontinuing the practice of setting limits on the interest rates of banks' deposit and lending operations, leaving banks to set the relevant rates. The implementation of recent MFD recommendations to improve central bank monetary operations and liquidity management was a major step in the right direction.

\section{E. Conclusion}

53. The authorities have recently introduced a number of measures to enhance the operations of financial markets in Guinea, but much remains to be done. In particular, the central bank should level the playing field for all operators in the foreign exchange market. At the same time, the authorities should take steps to promote a freer and more flexible market for instruments denominated in local currency. These policies would help ensure a healthier foreign exchange market and a stronger framework for the implementation of monetary policy while promoting soundness and good business practices in the banking system. 


\section{References}

Basu, Anupam; Blavy, Rodolphe; Yulek, Murat, 2004, "Microfinance in Africa: Experience and Lessons from Selected African Countries", IMF, Working Paper 04/174 (Washington: International Monetary Fond)

Duttagupta, Rupa; Fernandez, Gilda; Karacadag, Cem, 2004, "From Fixed to Float: Operational Aspects of Moving Toward Exchange Rate Flexibility", IMF, Working Paper 04/126 (Washington: International Monetary Fond)

Hardy, Daniel C.; Holden, Paul; Prokopenko, Vassili, 2002, "Microfinance Institutions and Public Policy”, IMF, Working Paper 02/159 (Washington: International Monetary Fond) 


\section{CoMpetitiveness AND EQUILIBRIUM EXChANGE RATE IN GUINEA ${ }^{17}$}

\section{A. Introduction}

54. The Guinean franc has continuously depreciated in real terms since 1989. By the end of 2004, it had lost about 40 percent of its value in real terms. ${ }^{18}$ In March 2005, the Guinean authorities adopted a flexible exchange rate regime by ending the official auctions (which had become a vehicle for administrating the rate) and allowing banks and authorized exchange bureaus to buy and sell foreign exchange at the market rate. Since then, the Guinean franc has lost about one-third of its nominal value and has depreciated by about 12 percent in real terms. The cumulative depreciation of the real effective exchange rate from January 1990 to July 2005 now amounts to 51 percent. A depreciation of this magnitude raises the question as to what extent it can be considered as an equilibrium phenomenon and how far it has affected the competitiveness of the Guinean economy. In this paper, we address these questions by estimating an equilibrium path for Guinea's real effective exchange rate between 1975 and 2004 to assess the extent of real exchange rate misalignment. We then review developments in other available indicators of external competitiveness.

55. The outline of the remainder of this paper is as follows. Section B provides a brief presentation of the evolution of Guinea's exchange rate regime. Section $\mathrm{C}$ investigates the presence of a long-run cointegration relationship between the real exchange rate and certain explanatory variables and estimates the extent to which the real exchange rate has diverged from its equilibrium level since the 1980s. Section D examines developments in key indicators of external competitiveness other than the real effective exchange rate. Section $\mathrm{E}$ concludes the paper.

\section{B. Background and Recent Developments}

\section{Developments in the foreign exchange rate regime}

56. After achieving independence, Guinea adopted its own currency, the Guinean Syli (GS). The Syli was pegged to the SDR on June 11, 1975 at the rate of GS 24.68 per SDR. The currency became increasingly overvalued, and, by mid-1985, its rate exceeded GS 280 per SDR in the parallel market. With a view to attracting foreign exchange to official channels, the government created a second market for foreign exchange in October 1985. This market was limited to sales to the banking system of foreign exchange originating from capital inflows and nonmining current account receipts. In early January 1986, the Syli was replaced by the Guinean franc (GF) at GF 300 per U.S. dollar in the official market and GF 340 per U.S. dollar in the second market, in which the exchange rate was set at weekly auctions for foreign exchange organized by the central bank.

\footnotetext{
${ }^{17}$ Prepared by Fabien Nsengiyumva.

18 Based on the real effective exchange rate (REER) as published by the IMF, which is computed by using the official nominal exchange rate and the relative consumer price of Guinea vis-à-vis its main trade partners.
} 
57. In October 1994, the authorities adopted a flexible exchange rate regime and introduced an interbank market for foreign exchange. The official exchange rate (also called the reference rate) was calculated daily as a weighted average of exchange rates quoted by banks. The introduction of this market was preceded by a series of reforms in the foreign exchange system, including a liberalization of activities of foreign exchange bureaus in 1993, the liberalization of payments and transfers for current transactions, and the possibility for residents to open bank accounts in foreign currency. The foreign exchange bureaus were not allowed to participate in the interbank market. The central bank had indicated that it would intervene in the market only to smooth short-term fluctuations and to meet its net foreign asset objectives. $^{19}$

58. As described in IMF staff reports published after 1994, the interbank foreign exchange market did not function as intended. Under the apparent influence of the central bank in resisting the depreciation of the exchange rate, commercial banks failed to let the exchange rate reflect market forces. The gap between the interbank market rate and the parallel market rate averaged about 6 percent during 1995-99. The foreign exchange auction system was reestablished in late 1999.

59. During 2000-02, the shortage of foreign exchange in the official market forced the central bank to move from weekly to monthly auctions in an effort to increase the volume offered at each auction. The depreciation of the official rate was moderate throughout the period (10 percent from January 2000 to December 2002). In addition, the rate of dispersion of the bid prices, as well as the gap between the maximum and the minimum price bid, fell continuously over the period, indicating that bidding was not purely competitive and that the bidders seemed to have knowledge about the outcome. However, the spread between the official (bank) and parallel (nonbank) exchange rates remained low, at about 1.5 percent on average, during the period.

60. Between late 2002 and mid-July 2004, the authorities pegged the official exchange rate against the U.S. dollar and increasingly used the auction mechanism as an administrative vehicle to allocate foreign exchange. ${ }^{20}$ As Guinea's macroeconomic situation deteriorated, the spread between the parallel and official rates gradually widened from about 2 percent at end-2002 to about 20 percent by late 2003 . The official auction of foreign exchange was suspended from November 2003 to July 2004, and commercial banks resorted to providing limited amounts of foreign exchange to some of their privileged clients. The excess demand spilled over into the nonbank market, and, because of the continued deterioration of the macroeconomic situation, the spread between the official and parallel rates widened further to about 35 percent by mid July 2004.

\footnotetext{
${ }^{19}$ The central bank apparently intervened quite frequently to prop up the currency by selling foreign exchange, thanks to large inflows of project and budgetary aid.

${ }^{20}$ The official market became a small pool of captive mining resources used to finance selective imports (mainly petroleum and rice) and debt service, and the nonbank market remained the default market for most exchange transactions.
} 
61. To make the exchange rate flexible and ease the pressure on its foreign reserves, the central bank reintroduced the exchange auction market mechanism in mid-July 2004, widened participation in the market to include exchange bureaus, and increased the frequency of the auction to weekly sessions. However, the amounts offered were relatively small (about US $\$ 500,000$ to banks and US\$30,000 to exchange bureaus). The official rate was devalued by 27 percent during the third quarter of 2004 and by a further 10 percent in early 2005 . The free market premium narrowed to less than 15 percent at the end of July 2004, then rose significantly after the central bank further restricted access to the official exchange market, advising private sector operators, in writing, to seek foreign exchange in the nonbank market. Despite the devaluation of the official exchange rate, the market premium averaged 25 between August 2004 and February 2005.

62. On March 1, 2005, the central bank abandoned the official foreign exchange auction mechanism and liberalized the foreign exchange market. Since then, the official exchange rate has been determined weekly by a reference rate calculated as an arithmetic average of rates quoted by deposit banks and authorized nonbank foreign exchange bureaus. The central bank has not intervened in the market so far. By end-September 2005, the reference rate had depreciated in foreign currency terms by about 35 percent against the U.S. dollar, compared with the official exchange rate from the last foreign exchange auction at end-February 2005. The pace of depreciation was rapid during the first four months following the adoption of the new foreign exchange regime, mostly resulting from pent-up demand for foreign currency assets and delays in implementing measures to ensure the efficient operation of the foreign exchange market. The depreciation has slowed since mid-July, indicating that the pent-up demand for foreign currency assets has now largely been satisfied.

\section{Developments in the real effective exchange rate}

63. Three phases can be distinguished in the evolution of the real effective exchange rate since 1980 (see Figure III.1).

- $\quad$ During 1980-89, there was a strong and sustained appreciation of the real effective exchange rate, based on the official exchange rate. This appreciation is explained by the low and fixed nominal exchange rate, at a time when most of Guinea's trade partners had adopted flexible exchange rate regimes, and by Guinea's low inflation rates, generated by administered prices for most consumption goods and services.

- $\quad$ During 1990-97, the real effective exchange rate depreciated slowly but continuously as the authorities loosened price controls and later adopted modest flexibility of the nominal exchange rate. The slow real depreciation during that period is also explained by the government's efforts to maintain macroeconomic stability and improve the efficiency of the economy by implementing key structural reforms. ${ }^{21}$

${ }^{21}$ The 2004 ex post assessment of longer-term program engagement for Guinea (IMF Country Report No 04/377) notes that Guinea made considerable progress under its economic programs supported under an 
- $\quad$ From 1998 to 2004, the Guinean franc depreciated by about 28 percent in real terms, following a depreciation of about 48 percent in nominal (effective) terms and an increase of about 40 percent in the relative price index. ${ }^{22}$ The deterioration in some fundamentals, particularly the terms of trade and capital inflows, the slowdown in the implementation of key structural reforms, and increasing financial imbalances could have contributed

Figure III. 1. Real Effective Exchange Rate, 1975-

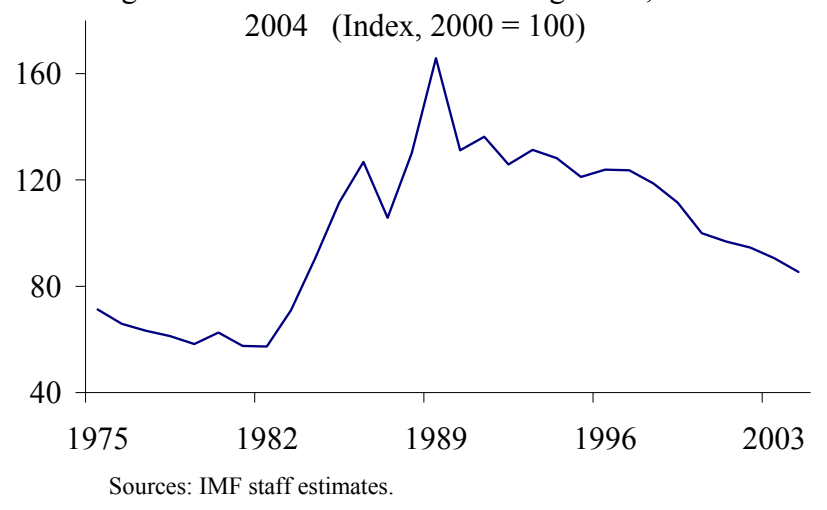
to the strong real depreciation during that period.

\section{Estimating the Long-Run Equilibrium Exchange Rate}

64. This section applies the fundamental equilibrium exchange rate (FEER) approach based on the Edwards (1989) model and the Johansen (1995) cointegration methodology to assess the long-run equilibrium level of Guinea's real exchange rate. ${ }^{23} \mathrm{We}$ first briefly present the methodology underlying the FEER approach and then estimate the long-run relationship between the REER and its fundamentals using the cointegration technique. Subsequently, we calculate the path of equilibrium real effective exchange rate (EREER) using the estimated parameters and nontransitory components of the determining fundamentals. The different steps followed by the FEER approach are presented in Appendix I.

\section{The empirical model}

65. Following Edwards (1989) and many other studies on developing countries, we include the following variables as the fundamentals underlying the equilibrium real exchange rate: the terms of trade, government current expenditure, total investment, technological progress, and capital inflows. This set of fundamentals was also dictated by the availability of

ESAF-arrangement during 1991-96, although the external situation did not improve as much as expected because of a sharp deterioration in the terms of trade and in fiscal management in 1995-96. It also notes that Guinea implemented important structural reforms during that period.

${ }^{22}$ Annual consumer price index (CPI) inflation averaged 5 percent during 1998-2002 but jumped to 12.9 percent in 2003 and 17.5 percent in 2004. The nominal exchange rate of the Guinean franc against the U.S. dollar increased from GF 1,237 to GF 2,267 per U.S. dollar between 1998 and 2004.

${ }^{23}$ There is a considerable wealth of theoretical and empirical work on estimating the real equilibrium exchange rate. For a recent review, see Driver and Westaway (2004). 
data and by stationarity constraints (see below). The postulated general relationship between the effective exchange rate and the fundamentals is defined as follows:

$$
\begin{aligned}
\ln \left(R E E R_{t}\right)= & \beta_{0}+\beta_{1} \ln \left(T O T_{t}\right)+\beta_{2} \ln \left(C G R_{t}\right)+\beta_{3} \ln \left(I N V_{t}\right) \\
& +\beta_{4} \ln \left(\text { PROD }_{t}\right)+\beta_{5}\left(C A P F_{t}\right)+e_{t},
\end{aligned}
$$

where $\ln$ denotes the natural logarithm; REER the CPI-based real effective exchange rate ${ }^{24}$ TOT merchandise terms of trade; $C G R$ Government current expenditure as a share of GDP; $I N V$ total investment as a share of GDP; PROD technological progress index; and CAPF capital flows.

The following are the expected signs of the fundamentals:

- $\quad$ Merchandise terms of trade, defined as the ratio of the world price of Guinea's exports to the world price of its imports. The expected sign is positive. The terms of trade affect the REER through the wealth effect, with a positive terms of trade shock inducing an increase in the domestic demand and, hence, an increase in the relative price of the domestic economy compared with foreign countries, which results in an appreciation of the REER. ${ }^{25}$

- Government current expenditure as a share of GDP. The expected sign is generally ambiguous, because an increase in government spending has to be financed through higher taxes, which would offset the effect on real appreciation through a decline in disposable income. If the increase in government spending were instead financed through money creation, then it would result in an appreciation of the real exchange rate. The outcome may also depend, however, on whether government spending is primarily directed toward nontradable or tradable goods.

- Investment as a share of GDP. The expected sign is positive. An increase in the investment share of GDP is likely to exert a pure spending effect that raises the demand for all goods and appreciates the real exchange rate.

\footnotetext{
${ }^{24}$ The definition of the REER has important implications for the interpretation of equation (1). In this study, the REER is defined in foreign currency terms. Assuming that there are only two countries in the world, domestic country $(d)$ and foreign country $(f)$, the REER in foreign currency terms for the domestic country would be defined as $R E E R_{d}=\left(R_{f d} * P_{d}\right) / P_{f}$, where $R_{f d}$ is the index of the nominal exchange rate, defined as units of foreign exchange per one unit of domestic currency, and $P_{d}$ and $P_{f}$ are the domestic and foreign aggregate price indices, respectively. An increase in $R E E R_{d}$ corresponds, in this case, to an appreciation of the domestic currency in real terms.

${ }^{25}$ Theoretically, a change in the terms of trade affects also the real exchange rate through a substitution effect between tradables and nontradables. Most empirical studies have found, however, that the wealth effect dominates the substitution effect (see Baffes, Elbadawi, and O'Connell, 1999).
} 
- $\quad$ Technological progress. This captures the Balassa-Samuelson effect, according to which productivity improvements will generally be concentrated in the tradables sector and an increase in productivity in a reference economy relative to a foreign country will raise the relative price of nontradables to that of tradables in the reference economy and, hence, cause the REER to appreciate. As in other studies (see, for example, MacDonald and Ricci, 2003; and Aguirre and Calderon, 2005), we use the ratio of GDP per capita in Guinea to the trade weighted average of GDP per capita of Guinea's trade partners. The expected sign is negative, because declining relative output per capita would depress domestic relative to foreign prices.

- $\quad$ Capital flows. The expected sign is positive. An increase in the capital inflows results in an increase of domestic aggregate demand and, hence, an appreciation of the REER.

\section{Empirical results}

66. To estimate equation (1), we must first pay attention to the time-series properties of the individual variables before we estimate the long-run relationship. Since fundamentals are defined as variables that affect the real effective exchange in the long run, they should have the same order of integration as the real effective exchange rate. If the real exchange rate is nonstationary, then any stationary variable cannot be a fundamental. This is because any variable that stochastically drifts permanently away from its mean cannot be affected in the long run by a variable that reverts to its mean.

67. Table III.1 (Appendix III) provides unit root tests for the fundamental variables using augmented Dickey-Fuller (ADF) statistics. The results show that all the variables are integrated at level 1 and are stationary in the first differences, suggesting that it is legitimate to search for a cointegration relationship among these variables. The determination of the level of integration has to be treated with caution, however, because the ADF test has less power in short time series.

68. The estimation results are presented in Table III. 2 (Appendix III). The top panel of the table shows the long-run parameters (the $\beta$ 's) together with their standard errors, and the bottom panel provides the feedback coefficient estimates (the $\alpha$ 's). The estimated coefficients represent elasticities in the case of terms of trade, government current expenditure, investment, and technological progress and semi-elasticities in the case of capital flows. The coefficients are significant for the terms of trade, government current spending, and capital inflows. The coefficient for total investment and technological progress is not different from zero at the percent significance level, as attested by their chi-square. The results of the cointegration tests are shown in Tables III. 3 and 4 (Appendix III). The outcome of the diagnostic tests indicates that only the $\mathrm{ARCH}$ test rejects the null hypothesis. The trace statistic points to a single cointegrating vector.

The long-run relationship between the real effective exchange rate and the fundamental variables is represented by the following equation: 


$$
\begin{aligned}
\ln \left(\text { REER }_{t}\right)= & 0.966 \ln \left(\text { TOT }_{t}\right)-0.719 \ln \left(C G R_{t}\right)-0.117 \ln \left(I N V_{t}\right) \\
& -0.277 \ln \left(\text { PROD }_{t}\right)+0.043\left(C A P F_{t}\right) .
\end{aligned}
$$

- The terms of trade are positively correlated with the REER, indicating that an improvement in the terms of trade would result in an appreciation of the long-run equilibrium real exchange rate through a possible wealth effect;

- Government current spending has an unexpected negative (depreciating) impact on the real effective exchange rate, which could be an indication that government spending in Guinea did not have a lasting positive impact on domestic prices.

- Investment is also negatively correlated with the REER. The effect is not, however, significantly different from zero.

- $\quad$ The long-term negative impact of technological progress confirms that Guinea's declining output per capita relative to its trade partners would depreciate the real exchange rate. The effect is not, however, significantly different from zero.

- $\quad$ As predicted, capital inflows have a small yet statistically significant positive impact on the REER.

69. The magnitude of the estimated elasticities for the terms of trade and government current expenditure is striking. A 10 percent improvement in the terms of trade would appreciate the real exchange rate by about 10 percent, and an increase of 10 percent in government current spending would depreciate the REER by 7 percent. For the six member countries of the Economic and Monetary Community of Central Africa (CEMAC), Tsangarides (2005) found an elasticity of 2.27 for the terms of trade and -0.44 for government consumption. However, the magnitude of each coefficient may strongly depend on the characteristics of each economy, as well as on the quality and length of the data series.

70. The bottom panel of Table III. 2 (Appendix III) shows the feedback coefficients for the cointegrating vector, or the short-run relationship of the EREER and its fundamentals. The coefficient for $\mathrm{D}[\ln (\mathrm{REER})]$ is positive, suggesting that, in the face of any deviation from the long-run equilibrium, the fundamentals do not jointly move the system back to equilibrium. The coefficients for CGR and CAPF are insignificantly different from zero, which could indicate that these fundamentals are not weakly exogenous with respect to the parameters of the cointegrating relationship.

71. The long-run relationship obtained by estimating the equation of the REER with its fundamentals above permits the calculation of EREER, defined as the level of the REER that is consistent in the long run with the equilibrium values of the explanatory variables. Based on the long-term coefficients obtained from the cointegration analysis, the series of EREER is computed using the long-term components of the fundamentals. These components are 
estimated by using a simple five-year moving average, which is the simplest smoothing method that is generally used in the literature. ${ }^{26}$

72. Figure III. 2 shows that Guinea's REER went through a period of overvaluation in the early 1980s, with the actual REER exceeding its equilibrium level. After the introduction of a new currency in January 1986, accompanied by the adoption of a more flexible exchange rate system, the real exchange rate remained close to its estimated equilibrium level until about 1997. Since then, the gap between the actual REER and its equilibrium level has slowly widened. These last episodes coincided with lax fiscal and monetary policies, increased political uncertainty, and sluggish implementation of structural reforms. ${ }^{27}$ An interesting further step to this study would be to examine how fiscal and monetary shocks, as well as short-term deviations of fundamentals from their equilibrium levels, affect the level of real exchange misalignment.

73. It is important to interpret these results with caution. Although the econometric results seem statistically significant, the derivation of the equilibrium real exchange rate ultimately depends on the assumptions underlying the calculation of the equilibrium values of the fundamentals. In an economy like Guinea's, with data deficiencies and without long time series, the values of the parameters may not capture the true nature of the relationship the model is intended to Figure III.2. Guinea: Actual and Equilibrium Exchange Rate, 1980-2004 represent.

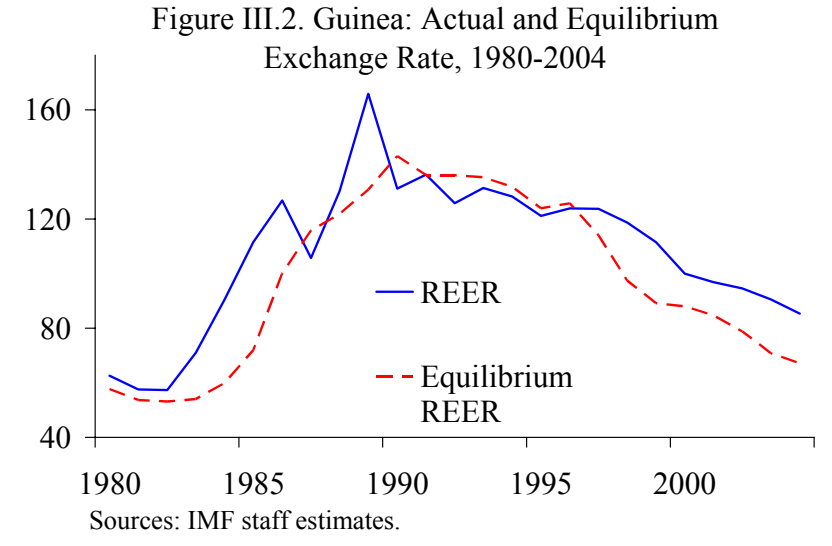

\section{Alternative Indicators of Guinea's External Competitiveness}

74. The real depreciation of a currency is often associated with an increase in an economy's external competitiveness. If the association were valid, the gradual depreciation of the Guinean franc in real terms over the past fifteen years would have generated an

\footnotetext{
${ }^{26}$ Other methods that have been used to estimate the long-term components of each fundamental series include the Hodrick-Prescott filter and the Beveridge-Nelson filter. For an overview of these methods, see Gonzalo and Granger (1995). Baffes, Elbadawi, and O'Connell (1999) noted the advantages of using the moving-average method in short time series.

${ }^{27}$ The estimated overvaluation of the REER in 2004 was about 20 percent. Assuming a pass-through coefficient of 0.25 of the nominal depreciation to the general price level, a 25 percent nominal depreciation of the Guinean franc (in foreign currency terms) would have been required to bring the REER to its equilibrium level. On the issue of how to estimate the size of a nominal depreciation required to achieve a given real depreciation, see Ghei and Hinkle (1999). These authors found that the pass-through coefficient in successful devaluations (those accompanied by appropriate macroeconomic policies) ranged between 0.2 and 0.55 .
} 
improvement in Guinea's export performance. The facts contradict, however, the theoretically predicted outcome: Guinea's export performance in the past several years has been weak in two particular aspects. First, Guinea's exports-to-GDP ratio averaged about 24 percent during 1994-2004, a level well below the country's past performance and the average for sub-Saharan Africa and most of Guinea's neighbors from the West African Economic and Monetary Union (Table III. 6, Appendix III). Second, Guinea's efforts to diversify its export base have had only limited success, and Guinea continues to depend heavily on three mining products: bauxite, alumina, and gold (Table III. 7, Appendix III). The estimated equilibrium exchange rate is one indicator that shows that relying on the evolution of the REER in assessing that of external competitiveness would be misleading. This section looks at other competitiveness indicators that could help explain Guinea's disappointing export performance, particularly the evolution of relative prices between tradables and nontradables and survey-based indicators of the business environment and governance. ${ }^{28}$

\section{Developments in the internal real exchange rate}

75. Most economists working on developing countries consider that the internal real exchange rate, defined as the ratio of the domestic prices of nontradable to tradable goods, is a more appropriate measure of competitiveness because it is the key relative price influencing resource allocation, and thus production, consumption, and ultimately external balance. Although the theoretical concept of the internal real exchange rate is reasonably straightforward, its empirical measurement raises the difficult practical problem of finding operational counterparts for the required price indices of tradable and nontradable goods. As a result, the literature uses a variety of approximations. In this paper, we depart from the twogood framework of the Swam-Salter "dependent economy" model by dividing the economy into three goods: exports, imports, and domestic goods. We consider that a two-good framework would be less appropriate for the following two reasons. First, the two-good framework aggregates imports and exports into one composite tradable good and assumes implicitly that the relative prices of imports and exports (terms of trade) are fixed. Guinea's experience proves that fluctuations of the terms of trade are so important that they cannot be ignored. Second, the aggregation of exports and imports in one composite tradable sector would generate a price index that is not directly related to standard national accounts price indices for either production or expenditure and does not then reflect the incentives generated by a change in internal real exchange rate either on the supply side or on the demand side of the economy.

76. The three-good framework produces two internal real exchange rate measures corresponding to the relative prices of exports and imports in terms of nontraded goods:

and

$$
\operatorname{IRERx}=P d / P x
$$

$$
I R E R m=P d / P m,
$$

${ }^{28}$ The lack of data precludes any analysis that would be based on relative unit labor costs and market shares. 
where $P d$ is the price of the domestic goods, and $P x$ and $P m$ are the domestic prices of exported goods and imported goods (measured in domestic currency terms), respectively. A small open economy can still influence $P x$ and $P m$ through trade taxes and similar policies. IRERx could be considered an indicator of the internal price competitiveness of exportables in production relative to domestically produced and consumed goods. It is a measure of the incentives guiding resource allocation between the domestic sectors producing these two categories of goods. A decrease in IRERx would indicate a gain in competitiveness for the exportable sector. Similarly, IRERm is an indicator of the internal price competitiveness of domestic goods relative to importables (or imported goods). The derivation of the proxies used in estimating these two internal real exchange rates is explained in Appendix II.

77. Figure III.3 compares the evolution of the three categories of real exchange rates. Two observations can be drawn from the figure. First, as expected, the three categories of real exchange rate have generally moved in the same direction. However, the two internal real exchange rates have been more volatile than the external real exchange rate. Moreover, the relative price of exportables has been even more volatile than the relative price of importables, because of the much greater cyclical variations in

Figure III.3. Guinea: Internal and External Real Exchange Rate, 1986 - $2004(1990=100)$

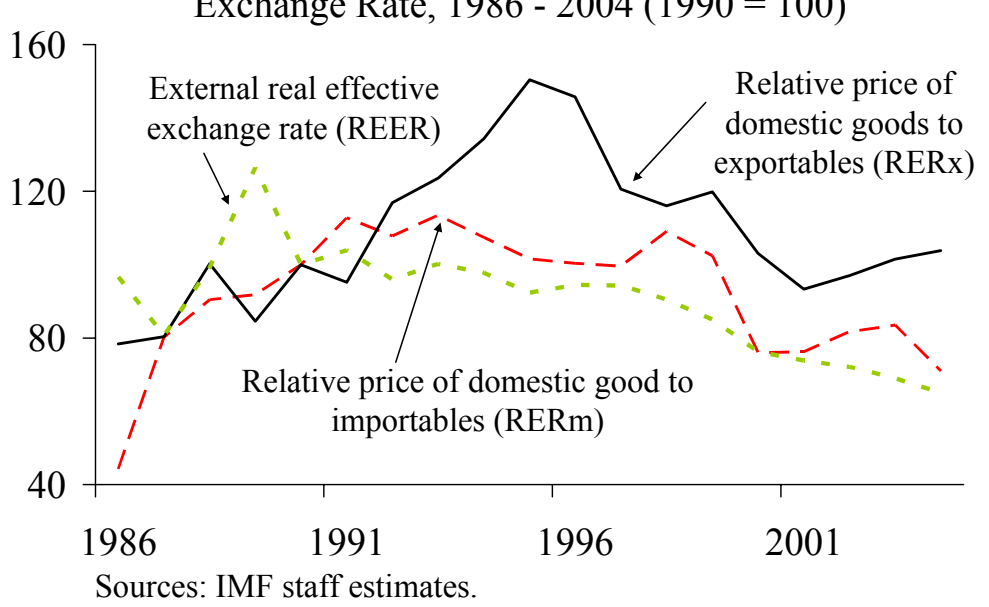
export prices. This higher volatility increases uncertainty, which is not captured by the real effective exchange rate and is detrimental to the export sector. Second, the relative price of exports in 2004 is almost at its 1990 level, while that of imports (or import-competing sector) has improved by almost 30 percent. This effect is also not reflected in the external real exchange rate. $^{29}$

\section{Survey-based indicators of the business environment and governance}

78. Two broad surveys with information on Guinea are available on the World Bank web site. The first one is the Doing Business survey, which covers 186 countries. The second one is the worldwide survey on governance, which produces worldwide governance indicators (see Kaufmann, Kraay, and Mastruzzi, 2005) and covers 199 countries.

\footnotetext{
${ }^{29}$ The total cumulative depreciation from 1990 to 2004 is 29 percent for the IRERm and 35 percent for the REER. IRERx, on the contrary, appreciated by 4 percent over the same period.
} 
79. Results of the Doing Business survey for Guinea point to key structural impediments to developing a competitive private sector. On 5 of the 10 indicators, Guinea ranks in the lowest 30 percent of all 186 countries ranked (Figure III.4). It performs particularly low on the cost of starting a business, obtaining licenses, getting credit, and paying taxes. Guinea also performs also below the average for sub-Saharan Africa on 13 of the 39 subindicators (Table III.5, Appendix III). In particular, the minimum capital required to start a business, the number of steps and days involved in obtaining a license, the cost to register a property, and the number of years required to resolve bankruptcies are higher than the average in sub-Saharan Africa.

80. Most of the indicators for governance in Guinea have also not significantly improved over the past eight years and some have even deteriorated (Figure III. 5). These indicators include government effectiveness, regulatory quality, rule of law, and control of corruption. The government effectiveness indicator combines information on the quality of public service provision, the quality of the bureaucracy, the competence of civil servants, the independence of the civil service from political pressures, and the credibility of the government's commitment to policies. Regulatory quality includes measures of the incidence of market-unfriendly policies, such as price controls or inadequate bank supervision, as well as perceptions of the burdens imposed by excessive regulation in areas such as foreign trade and business development. Rule of law includes measures of perceptions of the incidence of crime, the effectiveness and predictability of the judiciary, and the enforceability of contracts.
Figure III.4. Guinea's Rank on Indicators of

Business Environment, 2004-05

(Percentile rank, based on 186 countries)

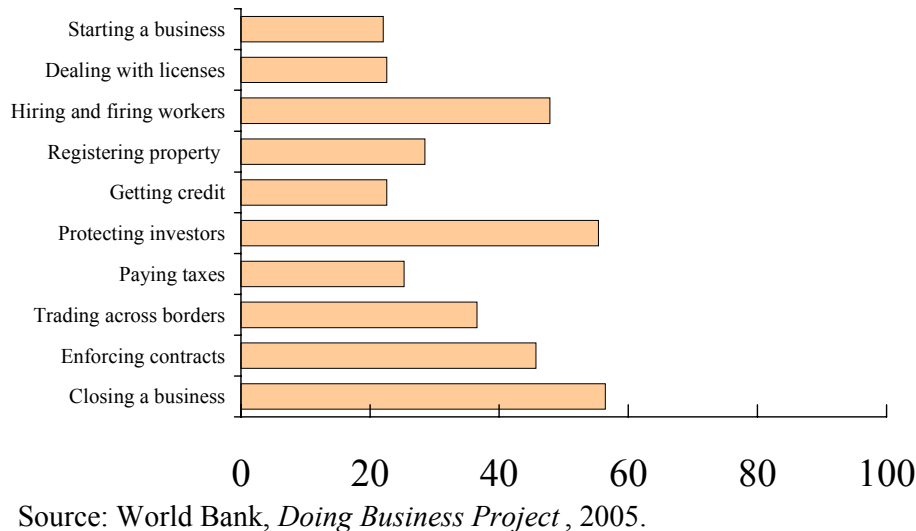

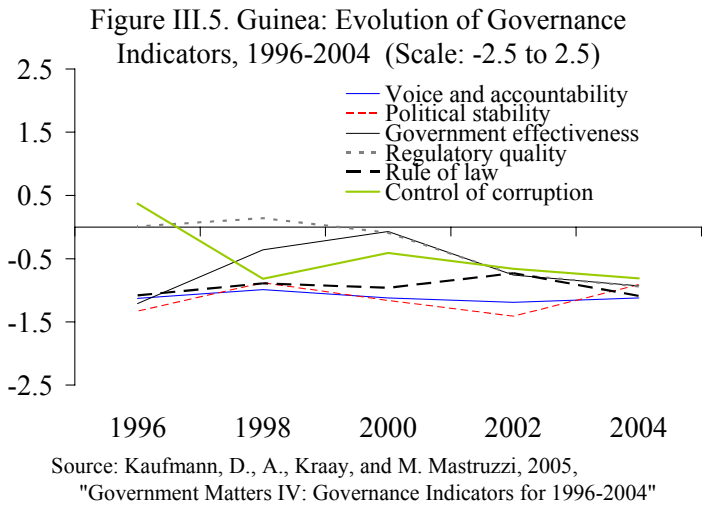

Figure III.6. Governance Indicators, Comparison (Percentile rank, 2004)

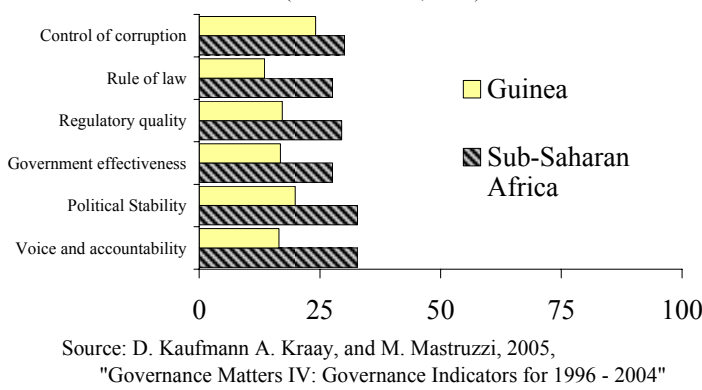
of Guinea with Sub-Saharan Africa 
Control of corruption includes perceptions of corruption defined as the exercise of public power for private gain. Guinea also ranks below average on important dimensions of governance compared to other sub-Saharan African countries (Figure III.6).

\section{E. Conclusion}

81. This paper shows that there has been an important loss of external competitiveness in Guinea in the last few years, based on several indicators,. First, the analysis based on the estimated equilibrium real exchange rate suggests that, while the REER depreciated continuously after 1989, it has become overvalued over the past six years. Second, the assessment of internal real exchange rate indicators shows that the relative price of exportable to domestic goods has been very volatile and has resulted in a loss of competitiveness for the exportable sector. Third, the examination of survey-based indicators concludes also that the loss of external competitiveness has been compounded by many other structural features that are detrimental to an export-oriented development strategy.

82. Strengthening the competitiveness of the external sector should continue to be one of the key objectives of the Guinean authorities' medium-term program. To this end, they should place emphasis on accelerating ongoing structural reforms aimed at improving the quality and availability of public services, strengthening the judicial framework and governance in the public sector in general and in the mining sector in particular, and reducing the active presence of the public sector in productive activities. By reducing factor costs, boosting labor productivity, and improving the quality of business environment and infrastructure, these reforms would create the conditions for an increase in domestic and foreign private investment in the export-oriented sectors.

83. Regarding exchange rate policy, the decision made by the authorities on March 1, 2005 , to abandon the foreign exchange auction and liberalize the foreign exchange operations goes in the right direction of closing the gap between the actual and the equilibrium real exchange rates. The nominal exchange rate of the Guinean franc vis-à-vis the U.S. dollar has depreciated by about 35 percent in foreign currency terms since end-February 2005, and the cumulative depreciation of the real effective exchange rate over the first eight months of 2005 amounted to 18 percent. The challenges for the authorities remain to create a liquid and efficient foreign exchange market, notably by (i) increasing information flows in the market on foreign exchange data, (ii) implementing a comprehensive surveillance of market transactions to ascertain the underlying sources and directions of foreign exchange flows, (iii) eliminating regulations that stifle market activity, and (iv) reducing barriers that may exist between and within the different segments of the foreign exchange market. 


\section{References}

Aguirre A., and C. Calderón, 2005, Real Exchange Rate Misalignments and Economic Performance, Central Bank of Chile Working Paper no 315.

Baffes, J., I.A. Elbadawi, and S.A. O’Connell, 1999, Single Equation Estimation of the Equilibrium Real Exchange Rate in Hinkle, L and Peter J. Montiel, Exchange Rate Misalignment: Concepts and Measurement for Developing Countries (Washington: World Bank).

Driver, R. L., and P. F. Westaway, 2004, Concepts of Equilibrium Exchange Rates, Bank of England Working Paper No. 248.

Edwards, S., 1989, Real Exchange Rates, Devaluation, and Adjustment: Exchange Rate Policy in Developing Countries (Cambridge, Massachusetts: MIT Press).

Gonzalo, J., and C. W. J. Granger, 1995, Estimation of Common Long-Memory Components in Co-Integrated Systems, Journal of Business and Economic Statistics, Vol. 13, pp 27-36.

Ghei N., and L. E. Hinkle, 1999, “A Note on Nominal Devaluation, Inflation, and the Real Exchange Rate" in Hinkle, L and Peter J. Montiel, Exchange Rate Misalignment: Concepts and Measurement for Developing Countries (Washington: World Bank).

Hinkle, L., and F. Nsengiyumva, 1999, "Internal Real Exchange Rates: Concepts and Measurement" in Hinkle, L and Peter J. Montiel, Exchange Rate Misalignment: Concepts and Measurement for Developing Countries (Washington: World Bank).

Johansen, S., 1995, "Likelihood-Based Inference in Cointegrated Vector Autoregressive Models (United Kingdom: Oxford University Press).

Kaufmann, D., A., Kraay, and M. Mastruzzi, 2005, Governance Matters III: Governance Indicators for 1996-2004, see http://www.worldbank.org/wbi/governance/govdata2002/.

MacDonald, R., and L. Ricci, 2003, Estimation of the Equilibrium Real Exchange Rate for South Africa, IMF Working Paper No. 03/44 (Washington: International Monetary Fund).

Tsangarides C., 2005, The Evolution of Actual and Equilibrium Real Effective Exchange Rates in the CEMAC Region, selected issue in the Staff Report for the Central African Economic and Monetary Community (IMF Country Report No. 05/390).

World Bank, Doing Business Project, database available via the internet: http://rru.worldbank.org/DoingBusiness/. 


\section{Methodology of the FEER Approach}

The FEER approach follows four steps:

- In the first step, historical data are used to estimate a long-run relationship between the real exchange rate and its fundamental determinants using cointegration techniques:

$$
q_{t}=f_{t}^{\prime} \beta+e_{t}
$$

where $q_{t}$ represents the real exchange rate, $f_{t}^{\prime}$ the vector of the fundamentals, $\beta$ the vector of cointegrating coefficients, and $e_{t}$ is the error term. Once cointegration is established, the significance of each variable in the cointegrating vector is tested. The fundamentals are also tested for weak exogeneity for the robustness of the model. The long-run relation identified by the cointegration test must also be validated by short-run adjustments captured by the following error-correction mechanism (ECM):

$$
\Delta q_{t}=\alpha e_{t-1}+\sum_{i=1}^{r} \gamma_{i} \Delta q_{t-i}+\sum_{i=0}^{s} \delta_{i} \Delta f_{t-i}+\sum_{i-0}^{s} \mu_{i} \Delta w_{t-i}+v_{t}
$$

The ECM indicates that the change in the exchange rate is affected by past deviations from the equilibrium, by its past changes, and by changes in fundamentals and other short-run variables, $w_{t}$. If, for instance, the exchange rate in the last period was overvalued relative to the fundamentals, then $e_{t-1}$ is positive, and, in this period, the real exchange rate corrects itself by an amount dictated by the coefficient $\alpha$ (adjustment speed). In accordance with convergence toward long-run equilibrium, this coefficient has to be negative, significant, and less than one (in absolute terms).

- The second step consists in estimating "normal" or "sustainable" values for the fundamentals by decomposing $f_{t}$ into permanent $f_{t}^{P}$ and transitory components $f_{t}^{T}$ :

$$
f_{t}=f_{t}^{P}+f_{t}^{T}
$$

- In a third step, permanent components of the fundamentals and the estimated regression coefficients $(\beta)$ are used to construct an equilibrium path for the real exchange rate

$$
q_{t}^{E}=f_{t}^{P} \beta_{t} .
$$

The estimated series of the equilibrium real exchange rate $\left(q_{t}^{E}\right)$ would vary over time to the extent that there are changes in the fundamentals.

- In the final step, the degree of real exchange rate misalignment is computed as the difference, at any moment in time, between the equilibrium and the actual real exchange rate. 


\section{Internal Real Exchange Rate}

The internal real exchange rate (IRER) measures a relative price between two different categories of domestic goods: tradables and nontradables. In this study, we use the indirect approach to measure the IRER by using a representative aggregate price index that includes both tradables and nontradables. There are three categories of goods in the economy: importables, exportables, and nontradables. In a three-good framework, there are two internal real exchange rates: the relative price of nontradables to exportables and the relative price of nontradables to importables. We use a proxy for each of these relative prices. ${ }^{30}$

\section{First proxy: the relative price of domestically produced and consumed goods to imported $\operatorname{good}($ IRER1)}

The aggregate price index used for this proxy is the consumer price index $(C P I)$, assumed to be a weighted average of the price of domestic goods $(\mathrm{Pd})$ and the price of imported goods $(\mathrm{Pm})$ in domestic currency terms:

$$
C P I=(P m)^{\alpha \cdot}(P d)^{1-\alpha},
$$

where $\alpha$ is the share of imported goods in the CPI basket.

IRER1 is defined as

$$
\text { IRERm }=P d / P m \text {. }
$$

Reorganizing and substituting (2) in (1), IRER 1 can be expressed as

$$
I R E R m=(C P I / P m)^{1 /(1-\alpha)} .
$$

We used EDSS (IMF) data for the CPI and the price of imports $(P m)$. The share of imports of foods and consumption goods in total private consumption is used as a proxy for $\alpha$.

\section{Second proxy: the relative price of domestically produced and consumed good to exported $\operatorname{good}($ IRERx)}

The aggregate price index used for this proxy is the GDP deflator, assumed to be a weighted average of the price of export good in domestic currency terms $(P x)$ and the price of domestic good $(P d)$ :

$$
P g=(P x)^{\beta \cdot}(P d)^{1-\beta},
$$

where $\beta$ is the share of real exports in total real output.

IRERx is defined as

$$
\text { IRERx }=P d / P x .
$$

By substituting (5) into (4), we obtain

$$
\operatorname{IRERx}=(P g / P x)^{1 /(1-\beta)}
$$

We used EDSS (IMF) data for the GDP deflator, the price of exports (Px), and the estimation of $\beta$.

\footnotetext{
${ }^{30}$ Several proxies for the IRER have been used in the literature. See a presentation of these proxies in Hinkle and Nsengiyumva (1999).
} 
Table III.1. Unit Root Tests

Variable Levels and Difference

\begin{tabular}{lccccc}
\hline Variable 1/ & Lags & ADF 2/ & & 1\% level & 5\% level \\
\hline $\ln (R E E R)$ & 0 & -1.478 & & -3.7 & -2.97 \\
$D[\ln (R E E R)]$ & 0 & -4.305 & $* *$ & -3.7 & -2.98 \\
$\ln (T O T)$ & 0 & -1.837 & & -3.7 & -2.97 \\
$D[\ln (T O T)]$ & 0 & -5.584 & $* *$ & -3.7 & -2.98 \\
$\ln (C G R)$ & 0 & -1.08 & & -3.7 & -2.97 \\
$D[\ln (C G R)]$ & 0 & -4.41 & $* *$ & -3.7 & -2.98 \\
$\ln (N I R)$ & 0 & -1.176 & & -3.7 & -2.97 \\
$D[\ln (N I R)]$ & 0 & -5.314 & $* *$ & -3.7 & -2.98 \\
$\ln (P R O D)$ & 0 & 0.281 & & -3.7 & -2.97 \\
$D[\ln (P R O D)]$ & 0 & -4.815 & $* *$ & -3.7 & -2.98 \\
$C A P F$ & 0 & -2.885 & & -3.7 & -2.97 \\
$D[C A P F]$ & 0 & -7.558 & $* *$ & -3.7 & -2.98 \\
\hline
\end{tabular}

$1 / \mathrm{D}$ denotes the difference operator.

2/ Based on Augmented Dickey-Fuller tests with an intercept but no linear trend. Two asterisks (**) next to the statistics indicates that the corresponding hypothesis cannot be rejected at the 1 percent confidence interval.

Table III. 2. Results of Cointegration Estimation Normalized Variable: ln (REER)

Estimates of the cointegrating relationships

$\ln$ (terms of trade)

$\ln$ (governement consumption)

$\ln$ (investment)

ln(technological progress)

Capital inflows

\section{Coefficients Chi-Square}

$0.966 \quad 5.4047$

$-0.719$

$-0.112$

$-0.277$

0.043
$\mathrm{P}$-value for the

test statistic 1/ $0.0201 *$

$0.0069 * *$

0.7967

0.1439

$0.0256 *$

Estimates of the short term impact/feedback coefficient

$\mathrm{D}[\ln (\mathrm{REER})]$

$\mathrm{D}[\ln ($ terms of trade $)]$

$\mathrm{D}[\ln ($ governement consumption) $]$

$\mathrm{D}[\ln$ (investment)]

$\mathrm{D}[\ln ($ technological progress $)]$

$\mathrm{D}$ [Capital inflows]

$\begin{array}{rr}0.142 & 0.7586 \\ -0.218 & 1.7045 \\ 0.412 & 4.6089 \\ 0.103 & 0.397 \\ -0.043 & 0.2718 \\ -12.511 & 5.3844\end{array}$

0.3838

0.1917

0.0318

0.5286

0.6022

0.0208

$1 / *$ and $* *$ indicate significance at the 5 percent and 1 percent level, respectively. 
Table III.3. Johansen Cointegration Tests

\begin{tabular}{lrrr}
\hline $\begin{array}{l}\text { Number of hypothesized } \\
\text { cointegrating equations }\end{array}$ & Eingenvalue & Trace statistic & T-prob. \\
\hline None* & & 98.640 & 0.032 \\
at most 1 & 0.68843 & 63.080 & 0.153 \\
at most 2 & 0.58358 & 36.798 & 0.361 \\
at most 3 & 0.52670 & 14.357 & 0.821 \\
at most 4 & 0.24562 & 5.902 & 0.710 \\
at most 5 & 0.16819 & 0.377 & 0.539 \\
\hline
\end{tabular}

Note: The trace test indicates 1 cointegrating equation at the 0.05 significance level.

Table III. 4. Diagnostic Tests

\begin{tabular}{lccc}
\hline Tests & Chi-squaire & P-value & \\
\hline AR & 1.2629 & 0.3035 & \\
Normality & 0.3139 & 0.8547 & \\
ARCH & 4.8934 & 0.0382 & $*$ \\
Heteroscedasticity & 2.3864 & 0.0889 & \\
\hline
\end{tabular}

Note: $*$ denotes rejection at the 5 percent level. 
Table III. 5. Guinea's Rank on Indicators of Business Environment and Governance During 2004-05

\begin{tabular}{|c|c|c|c|c|}
\hline & $\begin{array}{l}\text { Guinea's Rank } \\
\text { out of } 186 \\
\text { countries }\end{array}$ & Indicators & Guinea & $\begin{array}{c}\text { Sub-Saharan } \\
\text { Africa }\end{array}$ \\
\hline Starting a business & 145 & $\begin{array}{l}\text { Number of steps } \\
\text { Average number of days to go through these steps } \\
\text { Cost to launch a business } \\
\text { Deposit required ( } \% \text { of income per capita) }\end{array}$ & $\begin{array}{c}13 \\
49 \\
178.8 \\
405.0\end{array}$ & $\begin{array}{c}11 \\
63 \\
215.3 \\
297.2\end{array}$ \\
\hline Dealing with licenses & 144 & $\begin{array}{l}\text { Number of steps } \\
\text { Number of days to complete these steps } \\
\text { Cost (\% of income per capita) }\end{array}$ & $\begin{array}{c}29 \\
278 \\
512.2\end{array}$ & $\begin{array}{c}20 \\
251 \\
1597.3\end{array}$ \\
\hline Hiring and firing workers & 97 & $\begin{array}{l}\text { Difficulty of hiring index (range: } 0-100) \\
\text { Rigidity of hours index (range: } 0-100) \\
\text { Difficutlty of firing index (range: } 0-100) \\
\text { Rigidity of employment index (range: } 0-100 \text { ) } \\
\text { Hiring cost (\% of salary) } \\
\text { Firing costs (weeks of wages) }\end{array}$ & $\begin{array}{c}33 \\
80 \\
30 \\
48 \\
27 \\
25.5\end{array}$ & $\begin{array}{l}48.1 \\
63.2 \\
47.8 \\
53.1 \\
11.8 \\
53.4\end{array}$ \\
\hline Registering property & 133 & $\begin{array}{l}\text { Procedures (number) } \\
\text { Time (days) } \\
\text { Cost ( } \% \text { of property value) }\end{array}$ & $\begin{array}{c}6 \\
104 \\
15.6\end{array}$ & $\begin{array}{c}6 \\
117 \\
12.7\end{array}$ \\
\hline Getting credit & 144 & $\begin{array}{l}\text { Legal rights index (range: } 0-6 \text { ) } \\
\text { Credit information index (range: } 0-6) \\
\text { Public registry coverage (\% adults) } \\
\text { Private bureau coverage ( } \% \text { adults) }\end{array}$ & $\begin{array}{l}2 \\
1 \\
0 \\
0\end{array}$ & $\begin{array}{l}4.4 \\
1.5 \\
0.8 \\
3.5\end{array}$ \\
\hline Protecting investors & 83 & $\begin{array}{l}\text { Disclosure index } \\
\text { Director liability index } \\
\text { Shareholder suits index } \\
\text { Investor protection index }\end{array}$ & $\begin{array}{c}5 \\
6 \\
3 \\
4.7\end{array}$ & $\begin{array}{c}5.4 \\
4.7 \\
5 \\
5\end{array}$ \\
\hline Paying taxes & 139 & $\begin{array}{l}\text { Number of payments within a year } \\
\text { Number of hours spent } \\
\text { Total tax payable ( } \% \text { of gross profit) }\end{array}$ & $\begin{array}{c}55 \\
416 \\
51.2\end{array}$ & $\begin{array}{c}41 \\
39.4 \\
58.1\end{array}$ \\
\hline Trading across borders & 118 & $\begin{array}{l}\text { Documents for export (number) } \\
\text { Signatures for export (number) } \\
\text { Time for export (days) } \\
\text { Document for imports (number) } \\
\text { Signatures for import (number) } \\
\text { Time for import (days) }\end{array}$ & $\begin{array}{l}7 \\
11 \\
43 \\
12 \\
23 \\
56\end{array}$ & $\begin{array}{c}8 \\
18 \\
48 \\
12 \\
29 \\
60\end{array}$ \\
\hline Enforcing contracts & 101 & $\begin{array}{l}\text { Procedures (number) } \\
\text { Time (days) } \\
\text { Cost }(\% \text { of debt) }\end{array}$ & $\begin{array}{c}44 \\
306 \\
27.6\end{array}$ & $\begin{array}{c}35 \\
434 \\
41.6\end{array}$ \\
\hline Closing a business & 81 & $\begin{array}{l}\text { Years required to resolve bankruptcies } \\
\text { Cost to resolve bankruptcies (\% of estate value) } \\
\text { Recovery rate (cents on the dollar) }\end{array}$ & $\begin{array}{c}3.8 \\
8 \\
23.3\end{array}$ & $\begin{array}{c}3.3 \\
20 \\
16.1\end{array}$ \\
\hline
\end{tabular}

Source: World Bank, Doing Business Project, 2005. 
Table III. 6. Exports of Goods and Services, 1990 - 2004

(In percent of GDP)

\begin{tabular}{|c|c|c|c|c|c|c|c|c|c|c|c|c|c|c|c|c|}
\hline & 1990 & 1991 & 1992 & 1993 & 1994 & 1995 & 1996 & 1997 & 1998 & 1999 & 2000 & 2001 & 2002 & 2003 & 2004 & $\begin{array}{r}\text { Average } \\
1990-2004\end{array}$ \\
\hline Benin & 13.5 & 14.6 & 13.9 & 12.9 & 19.4 & 19.4 & 19.1 & 16.1 & 17.1 & 16.1 & 15.2 & 15.0 & 13.8 & 14.1 & 13.7 & 15.6 \\
\hline Cote d'Ivoire & 31.7 & 30.0 & 33.4 & 29.4 & 40.5 & 41.8 & 41.1 & 41.4 & 39.4 & 40.4 & 39.7 & 40.6 & 48.7 & 45.5 & 45.1 & 39.2 \\
\hline Ghana & 14.9 & 15.0 & 16.3 & 20.3 & 25.3 & 24.5 & 32.1 & 32.4 & 33.9 & 32.1 & 48.8 & 45.2 & 42.5 & 40.7 & 39.7 & 30.9 \\
\hline Guinea & 31.1 & 30.3 & 24.9 & 26.5 & 22.8 & 21.1 & 19.2 & 19.6 & 21.3 & 21.6 & 23.6 & 26.6 & 24.5 & 22.0 & 21.3 & 23.8 \\
\hline Mali & 15.9 & 16.8 & 16.3 & 15.6 & 19.2 & 18.8 & 18.2 & 23.3 & 21.4 & 23.3 & 24.1 & 29.0 & 31.9 & 26.6 & 27.7 & 21.9 \\
\hline Niger & 14.8 & 14.6 & 13.5 & 13.4 & 16.5 & 17.7 & 18.5 & 16.8 & 17.8 & 15.9 & 17.8 & 16.9 & 15.9 & 15.5 & 16.5 & 16.2 \\
\hline Senegal & 25.7 & 23.9 & 22.5 & 21.4 & 33.8 & 33.4 & 28.5 & 28.9 & 29.8 & 30.5 & 30.5 & 30.7 & 30.6 & 28.5 & 27.6 & 28.4 \\
\hline Togo & 31.6 & 31.2 & 25.2 & 21.5 & 27.1 & 29.4 & 29.3 & 25.4 & 31.4 & 29.2 & 32.3 & 33.7 & 35.2 & 45.1 & 47.8 & 31.7 \\
\hline Total Africa & 26.5 & 24.5 & 25.6 & 25.8 & 27.5 & 28.9 & 30.4 & 30.5 & 28.1 & 29.8 & 35.8 & 34.0 & 33.1 & 34.2 & 35.7 & 30.0 \\
\hline Sub-Saharan Africa & 27.3 & 25.5 & 25.4 & 26.0 & 28.0 & 28.9 & 30.7 & 30.6 & 28.8 & 30.2 & 35.5 & 33.7 & 32.7 & 33.8 & 35.2 & 30.2 \\
\hline WAEMU $1 /$ & 23.9 & 22.9 & 23.1 & 21.3 & 29.8 & 30.5 & 29.3 & 29.7 & 29.4 & 29.6 & 29.3 & 29.9 & 33.1 & 30.9 & 30.8 & 28.2 \\
\hline
\end{tabular}

Sources: IMF, World Economic Indicators, various years.

1/ WAEMU: West Africa Economic and Monetary Union

Table III. 7. Guinea: Exports of Goods, 1991-2004

\begin{tabular}{|c|c|c|c|c|c|c|c|c|c|c|c|}
\hline & 1991 & 1993 & 1995 & 1997 & 1998 & 1999 & 2000 & 2001 & 2002 & 2003 & 2004 \\
\hline & \multicolumn{11}{|c|}{ (In millions of U.S. dollars) } \\
\hline Total exports & 769.8 & 682.8 & 662.6 & 629.5 & 653.0 & 635.7 & 666.6 & 722.8 & 679.5 & 686.5 & 722.6 \\
\hline $\begin{array}{l}\text { Of which: } \\
\text { Mining }\end{array}$ & 700.0 & 590.9 & 527.6 & 512.1 & 544.5 & 537.8 & 570.6 & 636.5 & 619.9 & 25.0 & 666.9 \\
\hline Bauxite & 35.1 & 333.3 & 300.9 & 326.8 & 325.3 & 298.4 & 299.4 & 319.6 & 305.2 & 290.1 & 292.4 \\
\hline Alumina & 134.5 & 108.9 & 96.3 & 94.5 & 99.0 & 94.1 & 102.8 & 138.5 & 128.4 & 147.6 & 163.0 \\
\hline Diamonds & 50.7 & 70.0 & 35.3 & 56.8 & 48.4 & 50.8 & 51.3 & 28.1 & 34.5 & 48.7 & 48.2 \\
\hline Gold & 79.7 & 78.7 & 95.1 & 34.0 & 71.8 & 94.5 & 117.1 & 150.2 & 151.8 & 138.7 & 163.3 \\
\hline Coffee & 23.7 & 36.6 & 43.0 & 31.6 & 37.5 & 35.4 & 21.4 & 15.2 & 17.6 & 20.7 & 16.2 \\
\hline Fis & & 22 & 58 & 46.8 & 24 & 14 & 23 & 25 & 3 & 33.1 & 33.3 \\
\hline \multirow[t]{2}{*}{ Other } & 23.2 & 32.5 & 33.0 & 39.0 & 46.9 & 48.5 & 51.1 & 46.1 & 13.6 & 7.7 & 6.3 \\
\hline & \multicolumn{11}{|c|}{ (In percentage of total exports) } \\
\hline $\begin{array}{l}\text { Mining products } \\
\text { of which: }\end{array}$ & 90.9 & 86.5 & 79.6 & 81.4 & 83.4 & 84.6 & 85.6 & 88.1 & 91.2 & 91.0 & 92.3 \\
\hline Bauxite & 56.5 & 48.8 & 45.4 & 51.9 & 49.8 & 46.9 & 44.9 & 44.2 & 44.9 & 42.3 & 40.5 \\
\hline Alumina & 17.5 & 15.9 & 14.5 & 15.0 & 15.2 & 14.8 & 15.4 & 19.2 & 18.9 & 21.5 & 22.6 \\
\hline Diamonds & 6.6 & 10.3 & 5.3 & 9.0 & 7.4 & 8.0 & 7.7 & 3.9 & 5.1 & 7.1 & 6.7 \\
\hline Gold & 10.3 & 11.5 & 14.4 & 5.4 & 11.0 & 14.9 & 17.6 & 20.8 & 22.3 & 20.2 & 22.6 \\
\hline Coffee & 3.1 & 5.4 & 6.5 & 5.0 & 5.7 & 5.6 & 3.2 & 2.1 & 2.6 & 3.0 & 2.2 \\
\hline Fish & 3.0 & 3.3 & 8.9 & 7.4 & 3.7 & 2.2 & 3.5 & 3.5 & 4.2 & 4.8 & 4.6 \\
\hline Other & 3.0 & 4.8 & 5.0 & 6.2 & 7.2 & 7.6 & 7.7 & 6.4 & 2.0 & 1.1 & 0.9 \\
\hline
\end{tabular}

Sources : Guinean authorities; and IMF staff estimates. 
Table 1. Guinea: Selected Social and Demographic Indicators

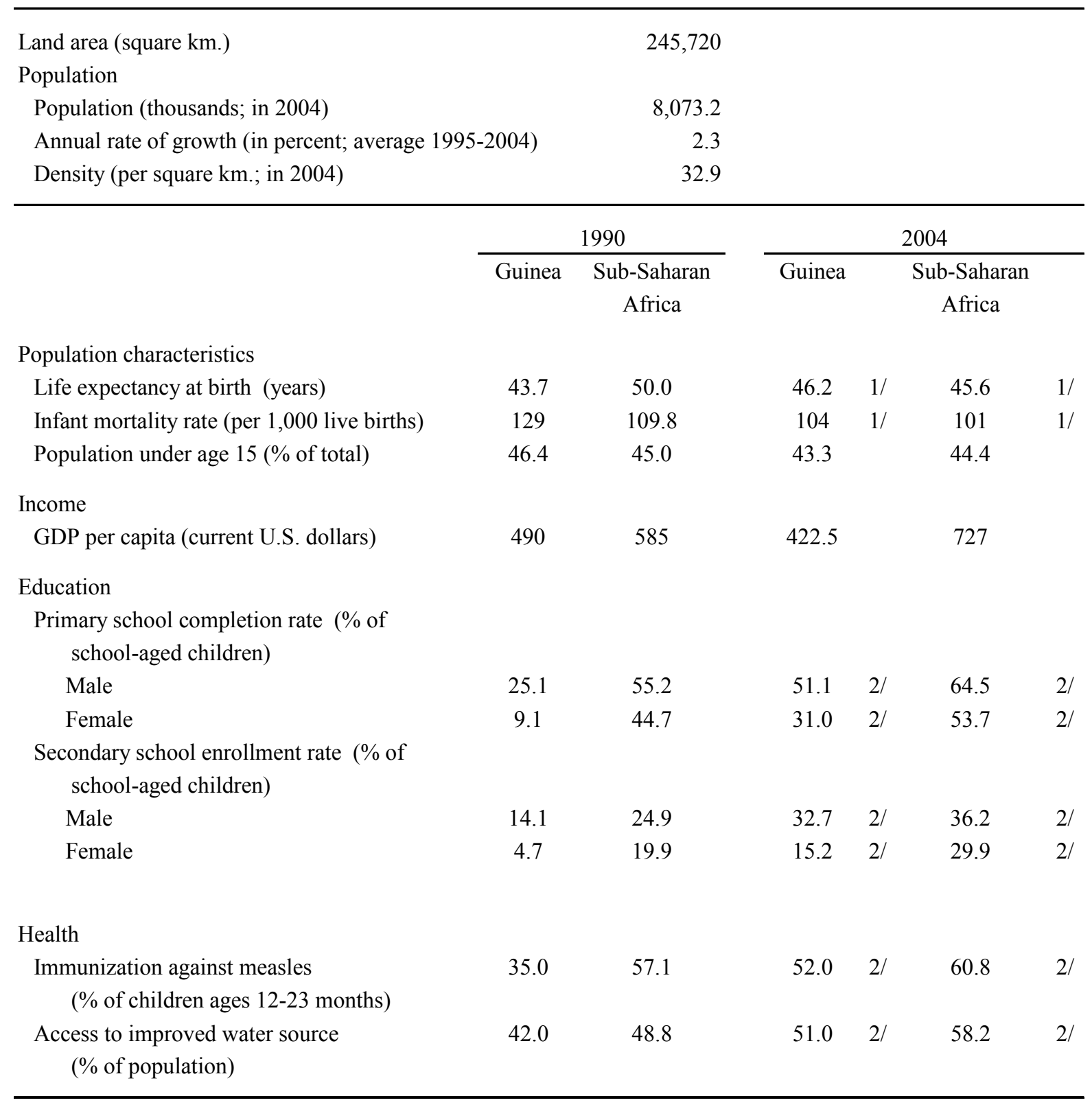

Sources: World Bank, World Development Indicators;

UN, Human Development Report, 2004; and IMF staff estimates.

1/ Data for 2003.

2/ Data for 2002. 
Table 2. Guinea: Selected Economic and Financial Indicators, 2000-04

\begin{tabular}{|c|c|c|c|c|c|}
\hline & 2000 & 2001 & 2002 & 2003 & 2004 \\
\hline & \multicolumn{5}{|c|}{ (Annual percentage change, unless otherwise indicated) } \\
\hline \multicolumn{6}{|l|}{ National income and prices } \\
\hline GDP at constant prices & 1.9 & 4.0 & 4.2 & 1.2 & 2.7 \\
\hline GDP at current prices & 13.2 & 8.9 & 7.1 & 13.7 & 24.9 \\
\hline GDP deflator & 11.1 & 4.7 & 2.8 & 12.3 & 21.7 \\
\hline \multicolumn{6}{|l|}{ Consumer prices } \\
\hline Average & 6.8 & 5.4 & 3.0 & 12.9 & 17.5 \\
\hline End of period & 7.2 & 1.1 & 6.1 & 14.8 & 27.6 \\
\hline \multicolumn{6}{|l|}{ External sector } \\
\hline Exports, f.o.b. (in U.S. dollar terms) & 4.9 & 8.4 & -2.0 & 3.3 & 1.6 \\
\hline Imports, f.o.b. (in U.S. dollar terms) & 4.3 & -3.7 & 6.1 & -3.0 & 22.4 \\
\hline Terms of trade (percentage change) & -7.8 & 8.1 & 2.4 & -2.4 & -16.8 \\
\hline \multicolumn{6}{|l|}{ Government budget } \\
\hline Domestic revenue & 14.9 & 12.7 & 14.0 & -1.3 & 24.1 \\
\hline Total expenditure & 15.4 & 24.7 & 3.9 & 20.6 & 4.9 \\
\hline Current expenditure & 17.3 & 35.8 & 13.4 & 21.0 & 8.2 \\
\hline Capital expenditure and net lending 1 / & 13.0 & 10.3 & -11.2 & 21.8 & -2.2 \\
\hline \multicolumn{6}{|l|}{ Money and credit } \\
\hline Net domestic assets $1 /$ & 28.2 & 2.1 & 31.2 & 50.5 & 26.9 \\
\hline Public sector (net) $1 /$ & 21.5 & 3.7 & 34.2 & 34.0 & 22.2 \\
\hline Private sector $1 /$ & 5.0 & 4.3 & 3.5 & 14.2 & 3.2 \\
\hline Broad money & 23.4 & 14.8 & 19.2 & 35.3 & 37.0 \\
\hline Reserve money & 17.0 & 11.0 & 18.3 & 27.4 & 33.0 \\
\hline \multirow[t]{2}{*}{ Velocity (GDP/average year-end M2) } & 10.3 & 9.4 & 8.6 & 7.7 & 7.0 \\
\hline & \multicolumn{5}{|c|}{ (In percent of GDP) } \\
\hline \multicolumn{6}{|l|}{ Central government finances } \\
\hline Total revenue and grants & 13.2 & 14.7 & 13.8 & 13.2 & 11.4 \\
\hline Current expenditure & 9.3 & 11.6 & 12.2 & 13.0 & 11.3 \\
\hline Capital expenditure and net lending $2 /$ & 7.2 & 7.2 & 6.0 & 6.3 & 5.0 \\
\hline \multicolumn{6}{|l|}{ Overall budget balance } \\
\hline Including grants (commitment) & -3.2 & -4.1 & -4.4 & -6.1 & -4.9 \\
\hline Excluding grants (commitment) & -5.5 & -7.5 & -6.2 & -8.9 & -5.9 \\
\hline Primary balance & 2.5 & 0.6 & 0.0 & -2.6 & -0.4 \\
\hline Gross investment & 19.7 & 15.3 & 13.1 & 9.9 & 10.9 \\
\hline \multicolumn{6}{|l|}{ External current account balance } \\
\hline Including official transfers & -6.4 & -2.7 & -4.3 & -3.4 & -5.5 \\
\hline \multirow[t]{2}{*}{ Excluding official transfers } & -7.2 & -4.8 & -5.6 & -4.1 & -5.8 \\
\hline & \multicolumn{5}{|c|}{ (In millions of U.S. dollars, unless otherwise indicated) } \\
\hline Overall balance of payments & 68.5 & -4.7 & -83.7 & -138.2 & -99.8 \\
\hline Gross official reserves (in months of imports) & 2.1 & 2.7 & 2.3 & 1.2 & 0.8 \\
\hline Gross reserves (in percent of broad money) & 48.3 & 61.3 & 41.9 & 20.9 & 15.8 \\
\hline Nominal GDP (in billions of Guinean francs) & $5,436.9$ & $5,919.7$ & $6,340.3$ & $7,209.8$ & $9,004.1$ \\
\hline
\end{tabular}

Sources: Guinean authorities; and IMF staff estimates and projections.

$1 /$ In percent of broad money stock at beginning of period.

2/ Includes expenditure for restructuring. 
Table 3. Guinea: GDP at Current Prices by Demand Component, 2000-04

\begin{tabular}{|c|c|c|c|c|c|}
\hline & 2000 & 2001 & 2002 & 2003 & 2004 \\
\hline & \multicolumn{4}{|c|}{ (In billions of Guinean francs) } & \\
\hline GDP at market prices & $5,436.9$ & $5,919.7$ & $6,340.3$ & $7,209.8$ & $9,004.1$ \\
\hline Consumption & $4,597.6$ & $5,094.8$ & $5,763.6$ & $6,668.7$ & $8,393.9$ \\
\hline Public & 370.7 & 405.6 & 477.5 & 559.5 & 566.8 \\
\hline Private & $4,226.9$ & $4,689.2$ & $5,286.1$ & $6,109.2$ & $7,827.0$ \\
\hline Investment & $1,071.2$ & 903.9 & 828.0 & 711.2 & 977.4 \\
\hline Fixed capital formation & $1,025.2$ & 849.9 & 814.4 & 707.5 & 976.2 \\
\hline Government & 264.1 & 288.4 & 254.9 & 317.7 & 355.2 \\
\hline Other sectors & 761.2 & 561.5 & 559.5 & 389.8 & 621.0 \\
\hline Change in stocks & 46.0 & 54.0 & 13.7 & 3.7 & 1.1 \\
\hline Foreign balance & -231.9 & -79.0 & -251.4 & -170.2 & -367.2 \\
\hline Exports of goods and nonfactor services & $1,283.2$ & $1,575.4$ & $1,550.9$ & $1,601.7$ & $1,868.5$ \\
\hline \multirow[t]{2}{*}{ Imports of goods and nonfactor services } & $1,515.2$ & $1,654.4$ & $1,802.3$ & $1,771.8$ & $2,235.7$ \\
\hline & \multicolumn{3}{|c|}{ (In percent of GDP) } & & \\
\hline GDP at market prices & 100.0 & 100.0 & 100.0 & 100.0 & 100.0 \\
\hline Consumption & 84.6 & 86.1 & 90.9 & 92.5 & 93.2 \\
\hline Public & 6.8 & 6.9 & 7.5 & 7.8 & 6.3 \\
\hline Private & 77.7 & 79.2 & 83.4 & 84.7 & 86.9 \\
\hline Investment & 19.7 & 15.3 & 13.1 & 9.9 & 10.9 \\
\hline Fixed capital formation & 18.9 & 14.4 & 12.8 & 9.8 & 10.8 \\
\hline Government & 4.9 & 4.9 & 4.0 & 4.4 & 3.9 \\
\hline Other sectors & 14.0 & 9.5 & 8.8 & 5.4 & 6.9 \\
\hline Change in stocks & 1.9 & 0.8 & 0.2 & 0.1 & 0.0 \\
\hline Foreign balance & -4.3 & -1.3 & -4.0 & -2.4 & -4.1 \\
\hline Exports of goods and nonfactor services & 23.6 & 26.6 & 24.5 & 22.2 & 20.8 \\
\hline Imports of goods and nonfactor services & 27.9 & 27.9 & 28.4 & 24.6 & 24.8 \\
\hline Domestic savings & 15.4 & 13.9 & 9.1 & 7.5 & 6.8 \\
\hline Gross national savings & 13.3 & 12.6 & 8.8 & 6.5 & 5.3 \\
\hline \multicolumn{6}{|l|}{ External current account balance } \\
\hline (including official transfers) & -6.4 & -2.7 & -4.3 & -3.4 & -5.5 \\
\hline
\end{tabular}

Sources: Guinean authorities; and IMF staff estimates. 
Table 4. Guinea: GDP at Constant 1996 Prices by Sector, 2000-04

\begin{tabular}{|c|c|c|c|c|c|}
\hline & 2000 & 2001 & 2002 & 2003 & 2004 \\
\hline \multicolumn{6}{|c|}{ (In billions of Guinean francs) } \\
\hline GDP at factor cost & $4,383.2$ & $4,559.4$ & $4,716.0$ & $4,782.6$ & $4,917.7$ \\
\hline Primary sector & 799.3 & 857.1 & 900.6 & 926.3 & 956.5 \\
\hline Agriculture & 507.4 & 549.4 & 581.9 & 598.8 & 619.8 \\
\hline Livestock & 159.2 & 164.7 & 171.1 & 177.9 & 182.7 \\
\hline Fisheries & 32.6 & 35.8 & 37.1 & 37.9 & 38.8 \\
\hline Forestry & 100.0 & 107.3 & 110.5 & 111.6 & 115.2 \\
\hline Secondary sector & $1,390.7$ & $1,464.8$ & $1,533.9$ & $1,539.9$ & $1,588.1$ \\
\hline Mining & 751.9 & 778.5 & 801.2 & 822.0 & 834.3 \\
\hline Manufacturing & 179.7 & 189.6 & 200.9 & 192.8 & 198.5 \\
\hline Water and electricity & 27.5 & 28.3 & 29.1 & 27.5 & 27.8 \\
\hline Construction & 431.6 & 468.4 & 502.7 & 497.7 & 527.5 \\
\hline Tertiary sector & $2,193.3$ & $2,237.5$ & $2,281.6$ & $2,316.4$ & $2,373.0$ \\
\hline Trade & $1,201.7$ & $1,225.8$ & $1,248.3$ & $1,267.0$ & $1,302.5$ \\
\hline Transport & 270.3 & 275.3 & 281.1 & 283.9 & 288.4 \\
\hline Administration & 249.3 & 250.8 & 257.0 & 260.9 & 267.4 \\
\hline Other & 472.0 & 485.7 & 495.1 & 504.6 & 514.6 \\
\hline Indirect taxes & 161.5 & 166.0 & 207.3 & 201.8 & 199.1 \\
\hline \multirow[t]{2}{*}{ GDP at constant prices } & $4,544.7$ & $4,725.4$ & $4,923.3$ & $4,984.3$ & $5,116.8$ \\
\hline & \multicolumn{4}{|c|}{ (Annual percentage change) } & \\
\hline GDP at factor cost & 2.1 & 4.0 & 3.4 & 1.4 & 2.8 \\
\hline Primary sector & -0.2 & 7.2 & 5.1 & 2.9 & 3.3 \\
\hline Agriculture & -3.9 & 8.3 & 5.9 & 2.9 & 3.5 \\
\hline Livestock & 6.4 & 3.4 & 3.9 & 4.0 & 2.7 \\
\hline Fisheries & 8.9 & 9.7 & 3.6 & 2.3 & 2.4 \\
\hline Forestry & 7.3 & 7.3 & 3.0 & 1.0 & 3.2 \\
\hline Secondary sector & 3.6 & 5.3 & 4.7 & 0.4 & 3.1 \\
\hline Mining & 1.6 & 3.5 & 2.9 & 2.6 & 1.5 \\
\hline Manufacturing & 7.0 & 5.5 & 6.0 & -4.0 & 3.0 \\
\hline Water and electricity & 3.5 & 3.0 & 3.0 & -5.5 & 0.9 \\
\hline Construction & 6.0 & 8.5 & 7.3 & -1.0 & 6.0 \\
\hline Tertiary sector & 1.9 & 2.0 & 2.0 & 1.5 & 2.4 \\
\hline Trade & 1.9 & 2.0 & 1.8 & 1.5 & 2.8 \\
\hline Transport & 1.5 & 1.8 & 2.1 & 1.0 & 1.6 \\
\hline Administration & 1.3 & 0.6 & 2.5 & 1.5 & 2.5 \\
\hline Other & 2.7 & 2.9 & 2.0 & 1.9 & 2.0 \\
\hline Indirect taxes & -2.9 & 2.8 & 24.9 & -2.7 & -0.8 \\
\hline GDP at constant prices & 1.9 & 4.0 & 4.2 & 1.2 & 2.7 \\
\hline
\end{tabular}

Sources: Guinean authorities; and IMF staff estimates. 
Table 5. Guinea: Consumer Price Index, 2000-04 (Period average)

\begin{tabular}{|c|c|c|c|c|c|}
\hline & 2000 & 2001 & 2002 & 2003 & 2004 \\
\hline & \multicolumn{4}{|c|}{ ( Index, Dec.1991=100) } & \\
\hline Aggregate index $1 /$ & 160.6 & 169.2 & 174.2 & 196.6 & \\
\hline Food & 169.6 & 177.2 & 188.1 & 223.6 & \\
\hline Nonfood & 154.0 & 163.4 & 164.2 & 177.2 & \\
\hline Clothing & 129.8 & 136.2 & 139.3 & 145.5 & \\
\hline Health & 165.4 & 170.7 & 175.5 & 185.2 & \\
\hline Housing & 138.9 & 146.1 & 147.4 & 155.9 & \\
\hline Electricity and water & 143.1 & 149.2 & 153.0 & 165.0 & \\
\hline Transportation & 175.2 & 189.4 & 170.9 & 199.0 & \\
\hline \multirow[t]{2}{*}{ Leisure and culture } & 170.7 & 190.2 & 208.3 & 218.8 & \\
\hline & \multicolumn{4}{|c|}{ (Annual percentage change) } & \\
\hline Aggregate index & 6.8 & 5.4 & 3.0 & 12.9 & \\
\hline Food & 4.0 & 4.5 & 6.1 & 18.9 & \\
\hline Nonfood & 9.1 & 6.1 & 0.5 & 7.9 & \\
\hline Clothing & 4.2 & 4.9 & 2.3 & 4.5 & \\
\hline Health & 4.5 & 3.2 & 2.8 & 5.5 & \\
\hline Housing & 3.7 & 5.2 & 0.9 & 5.7 & \\
\hline Electricity and water & 9.0 & 4.3 & 2.5 & 7.8 & \\
\hline Transportation & 25.6 & 8.1 & -9.8 & 16.4 & \\
\hline \multirow[t]{2}{*}{ Leisure and culture } & 3.5 & 11.4 & 9.5 & 5.0 & \\
\hline & \multicolumn{3}{|c|}{$($ Index, $2002=100)$} & & \\
\hline Aggregate index $1 /$ & & & & 110.8 & 130.1 \\
\hline Foods, beverages, and tobacco & & & & 116.1 & 147.1 \\
\hline Nonfood & & & & 107.6 & 119.9 \\
\hline Clothes and shoes & & & & 108.0 & 109.8 \\
\hline Housing, water, electricity, and gas & & & & 104.5 & 114.0 \\
\hline Furniture and equipment & & & & 108.5 & 120.2 \\
\hline Health & & & & 104.6 & 121.2 \\
\hline Transport & & & & 114.6 & 137.8 \\
\hline Entertainment and culture & & & & 102.6 & 109.0 \\
\hline Education & & & & 102.3 & 104.0 \\
\hline Hotels, cafés, and restaurants & & & & 101.8 & 123.1 \\
\hline \multirow[t]{2}{*}{ Other goods and services } & & & & 109.1 & 115.0 \\
\hline & \multicolumn{3}{|c|}{ (Annual percentage change) } & & \\
\hline Aggregate index & & & & & 17.5 \\
\hline Foods, beverages, and tobacco & & & & & 26.7 \\
\hline Nonfood & & & & & 11.5 \\
\hline Clothes and shoes & & & & & 1.7 \\
\hline Housing, water, electricity, and gas & & & & & 9.1 \\
\hline Furniture and equipment & & & & & 10.8 \\
\hline Health & & & & & 15.9 \\
\hline Transport & & & & & 20.3 \\
\hline Entertainment and culture & & & & & 6.2 \\
\hline Education & & & & & 1.6 \\
\hline Hotels, cafés, and restaurants & & & & & 20.9 \\
\hline Other goods and services & & & & & 5.4 \\
\hline
\end{tabular}

Sources: Guinean authorities; and IMF staff estimates.

1/ Change in CPI methodology in 2003 resulted in a break in the data series. 
Table 6. Guinea: Consumer Price Index, 2000-04 (End of period)

\begin{tabular}{|c|c|c|c|c|c|}
\hline & 2000 & 2001 & 2002 & 2003 & 2004 \\
\hline & \multicolumn{4}{|c|}{ ( Index, Dec.1991=100) } & \\
\hline Aggregate index $1 /$ & 168.1 & 170.0 & 180.4 & 207.1 & \\
\hline Food & 173.2 & 181.4 & 199.4 & 243.3 & \\
\hline Nonfood & 164.4 & 161.8 & 166.6 & 181.0 & \\
\hline Clothing & 134.2 & 137.1 & 144.8 & 147.0 & \\
\hline Health & 168.9 & 171.1 & 178.3 & 195.1 & \\
\hline Housing & 143.3 & 145.6 & 148.8 & 158.0 & \\
\hline Electricity and water & 148.2 & 151.2 & 155.5 & 165.2 & \\
\hline Transportation & 210.4 & 168.1 & 173.6 & 202.5 & \\
\hline \multirow{2}{*}{ Leisure and culture } & 172.6 & 208.2 & 210.3 & 224.3 & \\
\hline & \multicolumn{4}{|c|}{ (Annual percentage change) } & \\
\hline Aggregate index & 7.2 & 1.1 & 6.1 & 14.8 & \\
\hline Food & 1.8 & 4.7 & 9.9 & 22.0 & \\
\hline Nonfood & 11.7 & -1.6 & 3.0 & 8.6 & \\
\hline Clothing & 4.9 & 2.2 & 5.6 & 1.5 & \\
\hline Health & 5.4 & 1.3 & 4.2 & 9.4 & \\
\hline Housing & 5.8 & 1.6 & 2.2 & 6.2 & \\
\hline Electricity and water & 5.6 & 2.0 & 2.8 & 6.2 & \\
\hline Transportation & 33.7 & -20.1 & 3.3 & 16.6 & \\
\hline \multirow[t]{2}{*}{ Leisure and culture } & 5.6 & 20.6 & 1.0 & 6.7 & \\
\hline & \multicolumn{4}{|c|}{$($ Index, $2002=100)$} & \\
\hline Aggregate index 1/ & & & & 115.8 & 147.8 \\
\hline Foods, beverages, and tobacco & & & & 125.4 & 166.5 \\
\hline Nonfood & & & & 110.0 & 136.6 \\
\hline Clothes and shoes & & & & 111.2 & 114.1 \\
\hline Housing, water, electricity, and gas & & & & 105.0 & 128.0 \\
\hline Furniture and equipment & & & & 111.8 & 130.0 \\
\hline Health & & & & 108.4 & 145.6 \\
\hline Transport & & & & 116.6 & 172.4 \\
\hline Entertainment and culture & & & & 104.9 & 118.6 \\
\hline Education & & & & 104.1 & 111.8 \\
\hline Hotels, cafés, and restaurants & & & & 103.2 & 140.1 \\
\hline \multirow[t]{2}{*}{ Other goods and services } & & & & 112.3 & 120.4 \\
\hline & \multicolumn{3}{|c|}{ (Annual percentage change) } & & \\
\hline Aggregate index & & & & & 27.6 \\
\hline Foods, beverages, and tobacco & & & & & 32.8 \\
\hline Nonfood & & & & & 24.1 \\
\hline Clothes and shoes & & & & & 2.6 \\
\hline Housing, water, electricity, and gas & & & & & 21.9 \\
\hline Furniture and equipment & & & & & 16.3 \\
\hline Health & & & & & 34.3 \\
\hline Transport & & & & & 47.9 \\
\hline Entertainment and culture & & & & & 13.1 \\
\hline Education & & & & & 7.4 \\
\hline Hotels, cafés, and restaurants & & & & & 35.8 \\
\hline Other goods and services & & & & & 7.2 \\
\hline
\end{tabular}

Sources: Guinean authorities; and IMF staff estimates.

1/ Change in CPI methodology in 2003 resulted in a break in the data series. 
Table 7. Guinea: Financial Operations of the Central Government, 2000-04

\begin{tabular}{|c|c|c|c|c|c|}
\hline & 2000 & 2001 & 2002 & 2003 & 2004 \\
\hline & \multicolumn{4}{|c|}{ (In billions of Guinean francs) } & \\
\hline Revenue and grants & 719.8 & 873.0 & 876.9 & 952.7 & $1,027.4$ \\
\hline Revenue & 594.5 & 670.2 & 763.9 & 754.1 & 936.0 \\
\hline Mining sector revenue & 146.4 & 166.6 & 145.4 & 105.9 & 171.0 \\
\hline Nonmining sector revenue & 448.1 & 503.6 & 618.5 & 648.2 & 765.0 \\
\hline Direct taxes & 58.3 & 78.1 & 94.9 & 102.4 & 117.6 \\
\hline Indirect taxes & 335.9 & 362.5 & 452.4 & 497.0 & 584.7 \\
\hline Taxes on international trade & 119.1 & 114.0 & 139.1 & 149.1 & 181.9 \\
\hline Nontax revenue & 53.9 & 63.1 & 71.3 & 48.9 & 62.6 \\
\hline Grants & 125.3 & 202.8 & 113.0 & 198.6 & 91.4 \\
\hline Expenditure and net lending & 893.0 & $1,113.8$ & $1,157.4$ & $1,395.3$ & $1,464.2$ \\
\hline Current expenditure & 504.0 & 684.7 & 776.1 & 939.0 & $1,015.9$ \\
\hline Wages and salaries & 206.2 & 215.1 & 236.9 & 258.6 & 274.8 \\
\hline Other goods and services & 110.4 & 133.9 & 209.9 & 264.5 & 255.7 \\
\hline Subsidies and transfers & 97.6 & 246.1 & 224.0 & 263.2 & 260.4 \\
\hline Interest due on external debt & 73.9 & 62.1 & 74.1 & 83.4 & 120.6 \\
\hline Interest on domestic debt & 15.9 & 27.5 & 31.2 & 69.2 & 104.3 \\
\hline Public investment program & 386.6 & 423.4 & 368.9 & 453.4 & 444.0 \\
\hline Externally financed & 345.0 & 388.7 & 290.5 & 297.5 & 262.9 \\
\hline Domestically financed & 41.6 & 34.7 & 78.4 & 155.9 & 181.1 \\
\hline Banking system restructuring & 0.0 & 4.5 & 7.9 & 1.5 & 3.6 \\
\hline Net lending & 2.4 & 1.3 & 4.4 & 1.4 & 0.7 \\
\hline \multicolumn{6}{|l|}{ Balance, commitment basis } \\
\hline Including grants & -173.2 & -240.8 & -280.4 & -442.6 & -436.8 \\
\hline Excluding grants & -298.5 & -443.6 & -393.4 & -641.2 & -528.1 \\
\hline Excluding mining revenue & -444.9 & -610.2 & -538.8 & -747.1 & -699.2 \\
\hline Change in payments arrears & -38.0 & -4.4 & -52.4 & 54.9 & 47.9 \\
\hline Domestic & -43.3 & -4.1 & -49.5 & 45.8 & 21.4 \\
\hline External & 5.4 & -0.3 & -2.9 & 9.1 & 26.5 \\
\hline Adjustment for cash balances in bank & 10.9 & -15.9 & -26.8 & -16.0 & -20.9 \\
\hline Adjustment for foreign exchange loss & $\cdots$ & $\ldots$ & $\ldots$ & $\ldots$ & -34.5 \\
\hline Overall balance, cash basis & -200.3 & -261.1 & -359.6 & -403.8 & -444.3 \\
\hline Financing & 200.3 & 261.1 & 365.6 & 432.3 & 444.3 \\
\hline Net external financing & 110.4 & 244.8 & 104.5 & 58.2 & 121.8 \\
\hline Drawings & 224.3 & 346.5 & 215.8 & 165.2 & 204.9 \\
\hline Project financing & 221.2 & 229.1 & 213.9 & 143.2 & 204.9 \\
\hline Other & 3.1 & 117.4 & 1.9 & 22.1 & 0.0 \\
\hline Amortization due & -140.0 & -234.1 & -191.1 & -247.6 & -288.4 \\
\hline Arrears (reduction -) & 26.1 & 0.5 & -1.7 & 26.9 & 84.0 \\
\hline Debt relief & 0.0 & 133.5 & 83.1 & 119.7 & 80.0 \\
\hline Debt repurchase & 0.0 & -1.6 & -1.7 & -6.0 & -1.4 \\
\hline Net domestic financing & 89.9 & 16.2 & 261.1 & 374.1 & 322.5 \\
\hline Banking system & 105.5 & 21.8 & 230.3 & 272.1 & 240.4 \\
\hline Nonbank financing & -15.6 & -5.6 & 30.8 & 102.0 & 82.1 \\
\hline \multirow[t]{2}{*}{ Errors and omissions / Net financing gap } & 0.0 & 0.0 & -6.1 & -28.5 & 0.0 \\
\hline & \multicolumn{4}{|c|}{ (In percent of GDP) } & \\
\hline \multicolumn{6}{|l|}{ Memorandum items: } \\
\hline Revenue and grants & 13.2 & 14.7 & 13.8 & 13.2 & 11.4 \\
\hline Expenditure & 16.4 & 18.8 & 18.3 & 19.4 & 16.3 \\
\hline \multicolumn{6}{|l|}{ Balance, commitment basis } \\
\hline Including grants & -3.2 & -4.1 & -4.4 & -6.1 & -4.9 \\
\hline Excluding grants & -5.5 & -7.5 & -6.2 & -8.9 & -5.9 \\
\hline Balance, cash basis & -3.7 & -4.4 & -5.7 & -5.6 & -4.9 \\
\hline \multicolumn{6}{|l|}{ Domestic primary balance $1 /$} \\
\hline Including mining revenue & 2.5 & 0.6 & 0.0 & -2.6 & -0.4 \\
\hline Excluding mining revenue & -0.2 & -2.2 & -2.3 & -4.1 & -2.3 \\
\hline
\end{tabular}

Sources: Guinean authorities; and IMF staff estimates.

$1 /$ Revenue minus noninterest expenditure, excluding foreign-financed investment projects. 
Table 8. Guinea: Central Government Revenue, 2000-04

\begin{tabular}{|c|c|c|c|c|c|}
\hline & 2000 & 2001 & 2002 & 2003 & 2004 \\
\hline & \multicolumn{3}{|c|}{ (In billions of Guinean francs) } & & \\
\hline Total revenue & 594.5 & 670.3 & 763.9 & 754.1 & 936.0 \\
\hline Mining sector & 146.4 & 166.6 & 145.4 & 105.9 & 171.0 \\
\hline Profit taxes and dividends & 6.0 & 7.8 & 8.7 & 9.1 & 33.6 \\
\hline Special tax on mining products & 140.0 & 154.1 & 131.2 & 94.9 & 134.7 \\
\hline Other & 0.5 & 4.7 & 5.5 & 1.9 & 2.8 \\
\hline Nonmining sector & 448.1 & 503.6 & 618.5 & 648.2 & 765.0 \\
\hline Income and profit taxes & 58.3 & 78.1 & 94.9 & 102.4 & 117.6 \\
\hline Taxes on domestic production and trade & 216.8 & 248.5 & 313.2 & 347.9 & 402.8 \\
\hline Value-added tax (VAT) & 115.1 & 156.2 & 184.8 & 217.1 & 268.8 \\
\hline Excise surcharge & 7.2 & 10.8 & 10.6 & 15.1 & 14.9 \\
\hline Petroleum excise tax & 47.2 & 72.8 & 77.4 & 84.3 & 88.8 \\
\hline Other & 47.3 & 8.7 & 40.5 & 31.5 & 30.3 \\
\hline Taxes on international trade & 119.1 & 114.0 & 139.1 & 149.1 & 181.9 \\
\hline Import duties & 84.3 & 88.0 & 108.4 & 112.7 & 144.2 \\
\hline Taxes on exports & 4.0 & 5.2 & 5.8 & 9.9 & 0.6 \\
\hline Other $1 /$ & 30.8 & 20.8 & 24.9 & 26.6 & 37.1 \\
\hline \multirow[t]{2}{*}{ Nontax revenue and miscellaneous } & 53.9 & 63.1 & 71.3 & 48.9 & 62.6 \\
\hline & \multicolumn{4}{|c|}{ (In percent of GDP) } & \\
\hline \multicolumn{6}{|l|}{ Memorandum items: } \\
\hline Total revenue & 10.9 & 11.3 & 12.0 & 10.5 & 10.4 \\
\hline Mining sector revenue & 2.7 & 2.8 & 2.3 & 1.5 & 1.9 \\
\hline Nonmining sector revenue & 8.2 & 8.5 & 9.8 & 9.0 & 8.5 \\
\hline Income and profit taxes & 0.1 & 0.1 & 0.1 & 0.1 & 0.4 \\
\hline Taxes on domestic production and trade & 4.0 & 4.2 & 4.9 & 4.8 & 4.5 \\
\hline Taxes on international trade & 2.2 & 1.9 & 2.2 & 2.1 & 2.0 \\
\hline \multirow[t]{2}{*}{ Nontax revenue and miscellaneous } & 1.0 & 1.1 & 1.1 & 0.7 & 0.7 \\
\hline & \multicolumn{4}{|c|}{ (Annual percentage change) } & \\
\hline Total revenue & 14.9 & 12.8 & 14.0 & -1.3 & 24.1 \\
\hline Mining sector revenue & 24.8 & 13.8 & -12.7 & -27.2 & 61.6 \\
\hline Nonmining sector revenue & 12.1 & 12.4 & 22.8 & 4.8 & 18.0 \\
\hline Income and profit taxes & 1.0 & 34.0 & 21.5 & 7.9 & 14.9 \\
\hline Taxes on domestic production and trade & -5.2 & 14.6 & 26.1 & 11.1 & 15.8 \\
\hline Taxes on international trade & 47.4 & -4.3 & 22.0 & 7.2 & 22.0 \\
\hline Nontax revenue and miscellaneous & 64.2 & 17.2 & 12.9 & -31.4 & 28.1 \\
\hline
\end{tabular}

Sources: Guinean authorities; and IMF staff estimates.

1/ Including recovery of tax arrears. 
Table 9. Guinea: Central Government Expenditure, 2000-04

\begin{tabular}{|c|c|c|c|c|c|}
\hline & 2000 & 2001 & 2002 & 2003 & 2004 \\
\hline & \multicolumn{5}{|c|}{ (In billions of Guinean francs) } \\
\hline Total expenditure & 893.0 & $1,113.8$ & 1157.4 & 1395.3 & 1464.2 \\
\hline Current expenditure & 504.0 & 684.7 & 776.1 & 939.0 & 1015.9 \\
\hline Wages and salaries & 206.2 & 215.1 & 236.9 & 258.6 & 274.8 \\
\hline Other goods and services & 110.4 & 133.9 & 209.9 & 264.5 & 255.7 \\
\hline Subsidies and transfers & 97.6 & 246.1 & 224.0 & 263.2 & 260.4 \\
\hline Interest due on external debt & 73.9 & 62.1 & 74.1 & 83.4 & 120.6 \\
\hline Interest due on domestic debt & 15.9 & 27.5 & 31.2 & 69.2 & 104.3 \\
\hline Capital expenditure & 386.6 & 423.4 & 368.9 & 453.4 & 444.0 \\
\hline Domestically financed & 41.6 & 34.7 & 78.4 & 155.9 & 181.1 \\
\hline Foreign financed & 345.0 & 388.7 & 290.5 & 297.5 & 262.9 \\
\hline Cost of bank restructuring & 0.0 & 4.5 & 7.9 & 1.5 & 3.6 \\
\hline \multirow[t]{2}{*}{ Net lending } & 2.4 & 1.3 & 4.4 & 1.4 & 0.7 \\
\hline & \multicolumn{5}{|c|}{ (In percent of GDP) } \\
\hline Total expenditure & 16.4 & 18.8 & 18.3 & 19.4 & 16.3 \\
\hline Current expenditure & 9.3 & 11.6 & 12.2 & 13.0 & 11.3 \\
\hline Wages and salaries & 3.8 & 3.6 & 3.7 & 3.6 & 3.1 \\
\hline Other goods and services & 2.0 & 2.3 & 3.3 & 3.7 & 2.8 \\
\hline Subsidies and transfers & 1.8 & 4.2 & 3.5 & 3.7 & 2.9 \\
\hline Interest due on external debt & 1.4 & 1.0 & 1.2 & 1.2 & 1.3 \\
\hline Interest due on domestic debt & 0.3 & 0.5 & 0.5 & 1.0 & 1.2 \\
\hline Capital expenditure & 7.1 & 7.2 & 5.8 & 6.3 & 4.9 \\
\hline Domestically financed & 0.8 & 0.6 & 1.2 & 2.2 & 2.0 \\
\hline Foreign financed & 6.3 & 6.6 & 4.6 & 4.1 & 2.9 \\
\hline Cost of bank restructuring & 0.0 & 0.1 & 0.1 & 0.0 & 0.0 \\
\hline \multirow[t]{2}{*}{ Net lending } & 0.0 & 0.0 & 0.1 & 0.0 & 0.0 \\
\hline & \multicolumn{5}{|c|}{ (In billions of Guinean francs) } \\
\hline \multicolumn{6}{|l|}{ Memorandum items: } \\
\hline Defense expenditure & 80.3 & 171.1 & 193.8 & 167.0 & 181.8 \\
\hline Priority sector spending & 160.5 & 193.2 & 259.8 & 242.0 & 263.9 \\
\hline \multicolumn{6}{|l|}{ Of which: } \\
\hline Education (excluding higher education) & 74.1 & 79.5 & 111.0 & 110.6 & 150.4 \\
\hline \multirow[t]{2}{*}{ Health } & 21.7 & 48.8 & 47.6 & 37.3 & 35.2 \\
\hline & \multicolumn{5}{|c|}{ (In percent of GDP) } \\
\hline Defense expenditure & 1.5 & 2.9 & 3.1 & 2.3 & 2.0 \\
\hline Priority sector spending & 3.0 & 3.3 & 4.1 & 3.4 & 2.9 \\
\hline \multicolumn{6}{|l|}{ Of which: } \\
\hline Education (excluding higher education) & 1.4 & 1.3 & 1.8 & 1.5 & 1.7 \\
\hline Health & 0.4 & 0.8 & 0.8 & 0.5 & 0.4 \\
\hline
\end{tabular}

Sources: Guinean authorities; and IMF staff estimates. 
Table 10. Guinea: Monetary Survey, 2000-04 (In billions of Guinean francs, unless otherwise indicated)

\begin{tabular}{|c|c|c|c|c|c|}
\hline & 2000 & 2001 & 2002 & 2003 & 2004 \\
\hline \multicolumn{6}{|l|}{ Central bank } \\
\hline Net foreign assets $1 /$ & 53.6 & 119.9 & 52.1 & -66.9 & -75.4 \\
\hline (in millions of U.S. dollars) & 27.9 & 60.7 & 26.4 & -33.4 & -29.6 \\
\hline Net domestic assets & 289.7 & 261.1 & 398.4 & 640.8 & 838.7 \\
\hline Domestic credit & 241.8 & 227.5 & 392.7 & 580.0 & 742.0 \\
\hline Government (net) & 252.5 & 249.7 & 414.2 & 525.7 & 723.1 \\
\hline Of which: gold revaluation claims & 17.7 & 17.6 & 17.6 & 55.4 & 55.4 \\
\hline Public enterprises & 5.8 & 6.0 & 2.7 & 2.7 & 2.7 \\
\hline Private sector $1 /$ & 5.4 & 12.9 & 26.6 & 84.5 & 96.7 \\
\hline Claims on deposit money banks & -22.0 & -41.2 & -50.7 & -32.9 & -80.5 \\
\hline Of which: sterilization bills (-) & -30.0 & -44.3 & -60.8 & -34.5 & -82.5 \\
\hline Other items, net (assets + ) & 48.0 & 33.6 & 5.7 & 60.8 & 96.7 \\
\hline Reserve money & 343.3 & 381.0 & 450.5 & 573.9 & 763.3 \\
\hline Currency outside banks & 285.2 & 310.1 & 349.8 & 478.1 & 604.1 \\
\hline Bank reserves & 36.5 & 64.3 & 97.2 & 93.1 & 154.1 \\
\hline Deposits & 30.2 & 50.0 & 78.4 & 77.4 & 125.5 \\
\hline Required reserves & 15.3 & 19.5 & 24.8 & 33.3 & 48.4 \\
\hline Excess reserves & 14.9 & 30.5 & 53.5 & 44.1 & 77.1 \\
\hline Cash in till & 6.3 & 14.3 & 18.8 & 15.8 & 28.6 \\
\hline Private sector deposits & 21.7 & 6.6 & 3.6 & 2.7 & 5.1 \\
\hline \multicolumn{6}{|l|}{ Deposit money banks } \\
\hline Net foreign assets & 74.2 & 81.8 & 69.5 & 66.8 & 185.0 \\
\hline Bank reserves & 36.5 & 64.3 & 97.2 & 93.1 & 154.1 \\
\hline Deposits at the central bank & 30.2 & 50.0 & 78.4 & 77.4 & 125.5 \\
\hline Cash in till & 6.3 & 14.3 & 18.8 & 15.8 & 28.6 \\
\hline Liabilities to central bank (-) & 21.0 & 41.2 & 50.7 & 32.9 & 80.5 \\
\hline Of which: sterilization bills & 30.0 & 44.3 & 60.8 & 34.5 & 82.5 \\
\hline Domestic credit & 269.3 & 311.5 & 389.9 & 606.2 & 672.1 \\
\hline Credit to the government & -5.1 & 19.5 & 84.9 & 245.4 & 288.5 \\
\hline Claims & 18.0 & 47.0 & 115.0 & 285.9 & 386.2 \\
\hline Deposits & 23.1 & 27.5 & 30.1 & 40.5 & 97.7 \\
\hline Claims on public enterprises & 0.2 & 0.1 & 10.0 & 3.9 & 0.0 \\
\hline Claims on the private sector & 274.2 & 292.0 & 295.1 & 356.9 & 383.6 \\
\hline Other items, net (assets + ) & -122.4 & -143.7 & -159.8 & -196.6 & -216.3 \\
\hline Liabilities to the private sector & 278.6 & 355.1 & 447.6 & 602.5 & 875.4 \\
\hline Other items, net (assets + ) & -75.4 & -110.1 & -154.1 & -135.7 & -119.6 \\
\hline Broad money (M2) & 585.4 & 671.8 & 801.0 & $1,083.3$ & $1,484.6$ \\
\hline Currency & 285.2 & 310.1 & 349.8 & 478.1 & 604.1 \\
\hline Deposits & 300.3 & 361.7 & 451.2 & 605.2 & 880.5 \\
\hline Of which: foreign currency deposits & 85.6 & 106.5 & 120.3 & 157.9 & 271.0 \\
\hline \multicolumn{6}{|l|}{ Memorandum items: } \\
\hline Gross reserves (in months of imports) & 2.1 & 2.7 & 2.3 & 1.2 & 0.8 \\
\hline Broad money (12-month change in percent) & 23.4 & 14.8 & 19.2 & 35.3 & 37.0 \\
\hline Reserve money (12-month change in percent) & 17.0 & 11.0 & 18.3 & 27.4 & 33.0 \\
\hline Velocity (GDP/average M2) & 10.2 & 9.4 & 8.6 & 7.7 & 7.0 \\
\hline
\end{tabular}

Sources: Central Bank of the Republic of Guinea (BCRG); and IMF staff estimates.

1/ For 2003 and 2004, net foreign assets and credit to private sector of the central bank have been adjusted to take account of operations with a private company. 
Table 11. Guinea: Summary Accounts of the Central Bank, 2000-04 (In billions of Guinean francs)

\begin{tabular}{|c|c|c|c|c|c|}
\hline & 2000 & 2001 & 2002 & 2003 & 2004 \\
\hline Net foreign assets $1 /$ & 53.6 & 119.9 & 52.1 & -66.9 & -75.4 \\
\hline Gold & 25.4 & 16.6 & 183.7 & 3.1 & 9.4 \\
\hline IMF & -215.4 & -248.0 & -268.7 & -271.7 & -277.4 \\
\hline SDR holdings & 1.3 & 1.6 & 2.5 & 2.9 & 4.7 \\
\hline Foreign exchange holdings & 256.2 & 393.3 & 149.6 & 220.9 & 221.2 \\
\hline Short-term liabilities & -13.9 & -43.6 & -15.1 & -22.2 & -33.3 \\
\hline Net domestic assets & 289.7 & 261.1 & 398.4 & 640.8 & 838.7 \\
\hline Net domestic credit & 241.8 & 227.5 & 392.7 & 580.0 & 742.0 \\
\hline Public sector (net) & 258.3 & 255.8 & 416.9 & 528.4 & 725.8 \\
\hline Government (net) & 252.5 & 249.7 & 414.2 & 525.7 & 723.1 \\
\hline Of which: gold valuation & 17.7 & 17.6 & 17.6 & 55.4 & 55.4 \\
\hline Public enterprises & 5.8 & 6.0 & 2.7 & 2.7 & 2.7 \\
\hline Private sector $1 /$ & 5.4 & 12.9 & 26.6 & 84.5 & 96.7 \\
\hline Refinancing & 8.0 & 3.0 & 10.0 & 1.6 & 2.0 \\
\hline Sterilization bills $(-)$ & -30.0 & -44.3 & -60.8 & -34.5 & -82.5 \\
\hline Other items, net (assets + ) & 48.0 & 33.6 & 5.7 & 60.8 & 96.7 \\
\hline Revaluation accounts & 4.1 & 8.1 & 9.7 & 53.0 & 54.3 \\
\hline Adjustment IMF accounts & 4.9 & 3.0 & 0.1 & -9.6 & 0.2 \\
\hline Capital, reserves, and provisions & -20.2 & -25.1 & -20.4 & -18.7 & -26.0 \\
\hline SDR allocations & -5.8 & -5.8 & -5.8 & -5.8 & -5.8 \\
\hline Other (net) & 63.0 & 51.4 & 20.1 & 39.9 & 71.9 \\
\hline Other (central bank) & 2.0 & 2.0 & 2.0 & 2.0 & 2.0 \\
\hline Reserve money & 343.3 & 381.0 & 450.5 & 573.9 & 763.3 \\
\hline Currency outside banks & 285.2 & 310.1 & 349.8 & 478.1 & 604.1 \\
\hline Bank reserves & 36.5 & 64.3 & 97.2 & 93.1 & 154.1 \\
\hline Cash & 6.3 & 14.3 & 18.8 & 15.8 & 28.6 \\
\hline Deposits & 30.2 & 50.0 & 78.4 & 77.4 & 125.5 \\
\hline Private sector deposits & 21.7 & 6.6 & 3.6 & 2.7 & 5.1 \\
\hline Of which: in foreign currency & 4.7 & 3.3 & 0.2 & 0.1 & 3.1 \\
\hline
\end{tabular}

Sources: Central Bank of the Republic of Guinea (BCRG); and IMF staff estimates.

1/ For 2003 and 2004, net foreign assets and credit to private sector of the central bank have been adjusted to take account of operations with a private company. 
Table 12. Guinea: Summary Accounts of Deposit Money Banks, 2000-04 (In billions of Guinean francs)

\begin{tabular}{|c|c|c|c|c|c|}
\hline & 2000 & 2001 & 2002 & 2003 & 2004 \\
\hline Net foreign assets & 74.2 & 81.8 & 69.5 & 66.8 & 185.0 \\
\hline Assets & 151.2 & 136.1 & 145.9 & 136.2 & 282.0 \\
\hline Liabilities & 76.9 & 54.3 & 76.4 & 69.5 & 97.0 \\
\hline Claims on central bank & 57.5 & 103.8 & 142.5 & 121.2 & 234.6 \\
\hline Refinancing (-) & -9.0 & -4.8 & -15.5 & -6.4 & -2.0 \\
\hline Sterilization bills & 30.0 & 44.3 & 60.8 & 34.5 & 82.5 \\
\hline Banks' reserves & 36.5 & 64.3 & 97.2 & 93.1 & 154.1 \\
\hline Deposits & 30.2 & 50.0 & 78.4 & 77.4 & 125.5 \\
\hline Cash in till & 6.3 & 14.3 & 18.8 & 15.8 & 28.6 \\
\hline Domestic credit & 269.3 & 311.5 & 389.9 & 606.2 & 672.1 \\
\hline Claims on public sector & -4.9 & 19.5 & 94.8 & 249.3 & 288.5 \\
\hline Government (net) & -5.1 & 19.5 & 84.9 & 245.4 & 288.5 \\
\hline Claims & 18.0 & 47.0 & 115.0 & 285.9 & 386.2 \\
\hline Liabilities & 23.1 & 27.5 & 30.1 & 40.5 & 97.7 \\
\hline Public enterprises (PEs) & 0.2 & 0.1 & 10.0 & 3.9 & 0.0 \\
\hline Claims on private sector & 274.2 & 292.0 & 295.1 & 356.9 & 383.6 \\
\hline Healthy & 203.4 & 210.1 & 215.2 & 255.7 & 276.9 \\
\hline Nonperforming & 70.8 & 81.9 & 79.9 & 101.3 & 106.7 \\
\hline Other items, net & -122.4 & -141.9 & -154.3 & -191.7 & -216.3 \\
\hline Other assets & 60.5 & 62.1 & 81.6 & 89.0 & 134.1 \\
\hline Correspondents & 0.0 & 0.1 & 0.3 & 2.2 & 1.3 \\
\hline Immobilizations & 24.6 & 25.5 & 27.1 & 30.6 & 42.2 \\
\hline Other & 35.8 & 36.5 & 54.1 & 56.2 & 90.6 \\
\hline Other liabilities & -182.9 & -204.0 & -235.9 & -280.7 & -350.4 \\
\hline Correspondents & -3.0 & -11.9 & -15.8 & -16.8 & -13.4 \\
\hline Fonds propres & -124.8 & -134.9 & -161.5 & -194.0 & -229.8 \\
\hline Other & -55.2 & -57.3 & -58.5 & -69.9 & -107.2 \\
\hline Liabilities to private sector and PEs & 278.6 & 355.1 & 447.6 & 602.5 & 875.4 \\
\hline Deposits in Guinean francs & 197.7 & 251.8 & 327.5 & 444.7 & 607.4 \\
\hline Demand deposits & 177.1 & 223.0 & 298.8 & 382.5 & 513.4 \\
\hline Saving and time deposits & 20.6 & 28.8 & 28.7 & 62.2 & 94.0 \\
\hline Deposits in foreign currency & 80.9 & 103.3 & 120.1 & 157.8 & 268.0 \\
\hline
\end{tabular}

Sources: Central Bank of the Republic of Guinea (BCRG); and IMF staff estimates. 
Table 13. Guinea: Distribution of Banking Sector Credit by Sector and Maturity, 2000-04 (In percent, unless otherwise indicated)

\begin{tabular}{lrrrrr}
\hline & 2000 & 2001 & 2002 & 2003 & 2004 \\
& & & & & \\
\hline Trade & 60.7 & 59.7 & 59.9 & 53.9 & 62.9 \\
Construction, public works & 7.7 & 8.1 & 8.8 & 10.0 & 9.1 \\
Agriculture and texiles & 7.3 & 6.9 & 5.8 & 5.1 & 5.7 \\
Business services & 7.7 & 9.2 & 10.0 & 8.5 & 6.2 \\
Other manufacturing industries & 5.6 & 7.2 & 7.1 & 14.7 & 10.4 \\
Transport & 2.6 & 2.8 & 3.2 & 3.2 & 3.5 \\
Other sectors 1/ & 8.5 & 6.1 & 5.3 & 4.7 & 2.2 \\
Total & 100.0 & 100.0 & 100.0 & 100.0 & 100.0 \\
& & & & & \\
Maturity & & & & & \\
Total credit utilized & 68.1 & 68.1 & 64.7 & 72.1 & 66.4 \\
$\quad$ Short term & 57.5 & 59.5 & 57.3 & 60.1 & 59.2 \\
Medium term & 10.2 & 8.5 & 7.1 & 11.8 & 7.0 \\
$\quad$ Long term & 0.4 & 0.1 & 0.3 & 0.1 & 0.1 \\
Guarantees and liabilities & 31.9 & 31.9 & 35.3 & 27.9 & 33.6 \\
$\quad$ Total & 100.0 & 100.0 & 100.0 & 100.0 & 100.0 \\
Total (in billions of Guinean francs) & 397.3 & 411.3 & 436.2 & 477.3 & 537.7 \\
& & & & & \\
\hline
\end{tabular}

Source: Central Bank of the Republic of Guinea (BCRG).

1/ Includes exploitation of natural resources; extraction and production of minerals; energy and water production; and nonbusiness services. 
Table 14. Guinea: Structure of Interest Rates, 2000-04

(In percent per annum; end of period)

\begin{tabular}{lccccc}
\hline & 2000 & 2001 & 2002 & 2003 & 2004 \\
\hline Central bank and government rates & & & & & \\
Central bank refinancing rate 1/ & 11.5 & 16.3 & 16.3 & 16.3 & 16.3 \\
Treasury bills (BDT) & 14.7 & 13.4 & 13.3 & 13.2 & 14.7 \\
Central bank notes (TRM) & 13.0 & 12.6 & 12.5 & 11.3 & 12.3 \\
Commercial banks' rates & & & & & \\
Minimum savings deposit rate 2/ & 7.5 & 8.2 & 6.5 & 6.5 \\
\end{tabular}

Source: Central Bank of the Republic of Guinea (BCRG).

1/ In June 1993, central bank refinancing was discontinued, except for a limited number of on-lent donor lines of credit. Since then, the central bank rediscounts only treasury bills at a rate set at 3 percentage points above the prevailing treasury bill rate.

2/ Rate set by the central bank. 
Table 15. Guinea: Balance of Payments, 2000-04 (In millions of U.S. dollars, unless otherwise indicated)

\begin{tabular}{|c|c|c|c|c|c|}
\hline & 2000 & 2001 & 2002 & 2003 & 2004 \\
\hline Merchandise trade balance & 83.3 & 160.9 & 112.4 & 153.2 & 35.3 \\
\hline Exports, f.o.b. & 666.6 & 722.8 & 708.5 & 731.7 & 743.2 \\
\hline Of which: mining products & 570.6 & 636.5 & 619.9 & 625.0 & 666.9 \\
\hline Imports, f.o.b. & -583.3 & -561.9 & -596.2 & -578.5 & -707.9 \\
\hline Food products & -106.2 & -104.7 & -119.5 & -122.5 & -156.6 \\
\hline Other consumption goods & -87.4 & -83.0 & -97.0 & -99.4 & -122.4 \\
\hline Petroleum goods & -81.5 & -87.9 & -89.9 & -100.8 & -124.0 \\
\hline Intermediate and capital goods & -308.3 & -286.3 & -289.8 & -255.8 & -304.9 \\
\hline Services trade balance & -242.5 & -201.5 & -239.6 & -238.9 & -197.2 \\
\hline Services exports & 68.0 & 86.0 & 76.7 & 74.8 & 80.7 \\
\hline Of which: transport & 15.6 & 31.7 & 8.9 & 6.7 & 5.2 \\
\hline Services imports & -310.5 & -287.4 & -316.3 & -313.7 & -277.9 \\
\hline Of which: transport & -137.7 & -112.5 & -107.4 & -93.7 & -92.5 \\
\hline Income balance & -77.6 & -92.4 & -38.0 & -39.3 & -59.8 \\
\hline \multicolumn{6}{|l|}{ Of which: } \\
\hline Dividend payments & -8.4 & -45.7 & -1.2 & 0.0 & 0.0 \\
\hline Interest on public debt $1 /$ & -55.0 & -31.9 & -37.5 & -42.0 & -53.2 \\
\hline Transfers & 10.5 & 51.5 & 28.4 & 1.8 & 2.3 \\
\hline Net private transfers & -15.0 & -12.9 & -15.3 & -23.1 & -7.6 \\
\hline Official transfers & 25.5 & 43.8 & 25.5 & 4.9 & -4.8 \\
\hline HIPC Initiative assistance (multilateral) 2/ & 0.0 & 20.6 & 18.3 & 20.0 & 14.7 \\
\hline \multicolumn{6}{|l|}{ Current account } \\
\hline Including public transfers & -226.4 & -81.4 & -136.8 & -123.2 & -219.4 \\
\hline Excluding public transfers & -251.9 & -145.8 & -180.5 & -148.1 & -229.3 \\
\hline Capital account & 71.7 & 81.9 & 38.8 & 77.7 & 25.6 \\
\hline Public transfers (project grants) & 71.7 & 81.9 & 38.8 & 77.7 & 25.6 \\
\hline Financial account & -1.2 & 2.4 & 43.7 & 4.1 & 113.1 \\
\hline Public (medium and long term) & 48.3 & 60.4 & 12.5 & -41.5 & -30.6 \\
\hline Project-related loans & 126.6 & 117.6 & 108.3 & 72.1 & 90.3 \\
\hline Program financing & 1.8 & 60.3 & 1.0 & 11.1 & 0.0 \\
\hline Amortization due $1 /$ & -80.1 & -117.5 & -96.8 & -124.7 & -120.9 \\
\hline Direct and other private investment (net) & -47.2 & -58.0 & 31.2 & 55.9 & 97.9 \\
\hline Private short term & -2.3 & 0.0 & 0.0 & -10.3 & 45.8 \\
\hline Errors and omissions & 94.6 & -7.6 & -29.3 & -96.8 & -19.1 \\
\hline Overall balance & -61.3 & -4.7 & -83.7 & -138.2 & -99.8 \\
\hline Financing & 61.3 & 4.7 & 83.7 & 138.2 & 99.8 \\
\hline Change in official reserves & 43.3 & -43.6 & 43.8 & 59.8 & -3.9 \\
\hline Of which: net use of IMF resources & -8.0 & 14.6 & 5.4 & -16.4 & -22.5 \\
\hline Changes in arrears and govt. assets (net) & 18.0 & 0.1 & -2.3 & 18.1 & 48.7 \\
\hline Suspended debt service to Paris Club & 0.0 & 0.0 & 0.0 & 0.0 & 20.2 \\
\hline Debt relief & 0.0 & 48.1 & 42.1 & 60.3 & 34.8 \\
\hline \multicolumn{6}{|l|}{ Memorandum items: } \\
\hline \multicolumn{6}{|l|}{ Current account-GDP ratio (in percent) } \\
\hline Including public transfers & -7.4 & -2.7 & -4.3 & -3.4 & -5.5 \\
\hline Excluding public transfers & -8.2 & -4.8 & -5.6 & -4.1 & -5.8 \\
\hline Exports of GNFS-GDP ratio (in percent) 3/ & 24.0 & 26.6 & 24.5 & 22.2 & 20.8 \\
\hline Imports of GNFS-GDP ratio (in percent) 3/ & -29.2 & -27.9 & -28.4 & -24.6 & -24.8 \\
\hline External medium- and long-term public debt & 3261.0 & 3209.0 & 3045.6 & 3362.4 & 3270.3 \\
\hline In percent of GDP & 104.8 & 105.6 & 94.9 & 92.6 & 82.4 \\
\hline Gross reserves & 150.3 & 208.4 & 170.0 & 113.5 & 92.3 \\
\hline In months of imports of GNFS 3/ & 2.0 & 2.7 & 2.3 & 1.2 & 0.8 \\
\hline
\end{tabular}

Sources: Guinean authorities; and IMF staff estimates.

1/ Including payments on publicly guaranteed debt.

2/ HIPC Initiative: Heavily Indebted Poor Countries Initiative.

3/ GNFS: goods and nonfactor services. 
Table 16. Guinea: Composition of Merchandise Exports, 2000-04 (In millions of U.S. dollars, unless otherwise indicated)

\begin{tabular}{|c|c|c|c|c|c|}
\hline & 2000 & 2001 & 2002 & 2003 & 2004 \\
\hline Total exports, f.o.b. & 666.6 & 722.8 & 708.5 & 726.8 & 743.2 \\
\hline Mining products $1 /$ & 570.6 & 636.5 & 619.9 & 625.0 & 666.9 \\
\hline Other & 96.0 & 86.4 & 88.6 & 101.7 & 76.3 \\
\hline Bauxite & 299.4 & 319.6 & 305.2 & 290.1 & 292.4 \\
\hline CBG 2/ & 269.1 & 290.0 & 285.6 & 268.0 & 269.7 \\
\hline Volume (million tons) & 12.5 & 12.3 & 13.4 & 11.9 & 12.9 \\
\hline Price (U.S. dollars per ton) & 21.5 & 23.7 & 21.3 & 22.6 & 20.8 \\
\hline SBK 3/ & 20.8 & 20.4 & 19.7 & 22.1 & 22.7 \\
\hline Volume (million tons) & 1.4 & 1.6 & 1.8 & 1.9 & 2.1 \\
\hline Price (U.S. dollars per ton) & 14.6 & 12.8 & 11.0 & 11.7 & 11.0 \\
\hline Alumina (Friguia) & 102.8 & 138.5 & 128.4 & 147.6 & 163.0 \\
\hline Volume (thousand tons) & 570.9 & 679.7 & 674.6 & 731.2 & 785.8 \\
\hline Price (U.S. dollars per ton) & 180.0 & 203.8 & 190.3 & 201.9 & 207.4 \\
\hline Diamonds & 51.3 & 28.1 & 34.5 & 48.7 & 48.2 \\
\hline Arédor, Hymex, and Quatro & 18.6 & 4.5 & 6.4 & 4.8 & 3.0 \\
\hline Volume (thousand carats) & 41.4 & 25.5 & 22.2 & 28.5 & 40.1 \\
\hline Price (U.S. dollars per carat) & 450.2 & 175.1 & 286.7 & 169.7 & 75.9 \\
\hline Others & 32.7 & 23.7 & 28.2 & 43.9 & 45.1 \\
\hline Gold & 117.1 & 150.2 & 151.8 & 138.7 & 163.3 \\
\hline SMD 4/ & 24.6 & 29.5 & 31.9 & 29.6 & 35.8 \\
\hline Volume (tons) & 2.7 & 3.3 & 3.4 & 2.9 & 2.9 \\
\hline Price (U.S. dollars per ounce) & 283.0 & 280.0 & 293.6 & 319.4 & 389.0 \\
\hline SAG 5/ & 78.6 & 77.0 & 83.8 & 80.7 & 82.4 \\
\hline Volume (tons) & 8.7 & 8.9 & 8.4 & 7.9 & 6.3 \\
\hline Price (U.S. dollars per ounce) & 281.0 & 270.1 & 311.0 & 319.4 & 322.5 \\
\hline Other & 13.9 & 43.7 & 36.1 & 28.4 & 45.1 \\
\hline Volume (tons) & 2.9 & 4.3 & 4.7 & 3.8 & 4.4 \\
\hline Price (U.S. dollars per ounce) & 220.4 & 248.8 & 240.6 & 232.7 & 235.0 \\
\hline Coffee & 21.4 & 15.2 & 17.6 & 20.7 & 16.2 \\
\hline Volume (thousand tons) & 19.6 & 21.2 & 21.8 & 20.6 & 22.3 \\
\hline Price (thousand U.S. dollars per ton) & 1.1 & 0.7 & 0.8 & 1.0 & 0.7 \\
\hline Fish & 23.5 & 25.2 & 28.3 & 33.1 & 33.3 \\
\hline Other exports 6/ & 51.1 & 46.1 & 42.7 & 47.9 & 26.9 \\
\hline
\end{tabular}

Sources: Guinean authorities; and staff estimates.

1/ Exports of bauxite, alumina, diamonds, and gold.

2/ Compagnie Bauxite de Guinée.

3/ Société Bauxite de Kindia.

4/ Société Minière de Dinguirayo.

5/ Société Aurifère de Guinée.

6/ Comprises mainly food products. 
Table 17. Guinea: Composition of Imports, 2000-04

(In millions of U.S. dollars, unless otherwise indicated)

\begin{tabular}{|c|c|c|c|c|c|}
\hline & 2000 & 2001 & 2002 & 2003 & 2004 \\
\hline Total imports, f.o.b. & 583.3 & 561.9 & 596.2 & 578.5 & 707.9 \\
\hline $\begin{array}{l}\text { Adjustment for freight, insuranc } \\
\text { and transit trade }\end{array}$ & 111.1 & 107.0 & 116.7 & 45.2 & 59.7 \\
\hline Imports, c.i.f. & 694.4 & 668.9 & 712.9 & 623.7 & 767.6 \\
\hline Food products & 126.4 & 124.6 & 142.9 & 132.1 & 169.1 \\
\hline In constant 1996 prices & 192.8 & 184.5 & 224.3 & 194.6 & 221.5 \\
\hline Price index, $1990=100$ & 83.7 & 86.2 & 81.3 & 86.6 & 97.5 \\
\hline Other consumption goods & 104.0 & 98.8 & 116.0 & 107.1 & 132.2 \\
\hline In constant 1996 prices & 132.8 & 133.4 & 176.5 & 151.8 & 159.2 \\
\hline Price index, $1990=100$ & 91.4 & 86.4 & 76.7 & 82.3 & 96.8 \\
\hline Petroleum products & 97.0 & 104.6 & 107.5 & 108.7 & 137.1 \\
\hline In constant 1996 prices & 70.1 & 87.8 & 87.8 & 76.6 & 74.1 \\
\hline Price index, $1990=100$ & 28.2 & 24.3 & 25.0 & 28.9 & 37.7 \\
\hline Intermediate goods & 122.6 & 112.6 & 138.7 & 125.5 & 170.7 \\
\hline In constant 1996 prices & 156.5 & 152.1 & 211.0 & 177.8 & 205.7 \\
\hline Price index, $1990=100$ & 91.4 & 86.4 & 76.7 & 82.3 & 96.8 \\
\hline Capital goods & 244.4 & 228.3 & 207.9 & 150.3 & 158.5 \\
\hline In constant 1996 prices & 312.0 & 308.2 & 316.4 & 213.0 & 191.0 \\
\hline Price index, $1990=100$ & 91.4 & 86.4 & 76.7 & 82.3 & 96.8 \\
\hline \multicolumn{6}{|l|}{ Memorandum items: } \\
\hline Imports, c.i.f., 1996 prices & 814.4 & 833.7 & 926.4 & 732.2 & 762.5 \\
\hline Percentage change & -3.5 & 2.4 & 11.1 & -21.0 & 4.1 \\
\hline Import prices $(1996=100)$ & 85.3 & 80.2 & 77.0 & 85.2 & 100.7 \\
\hline Percentage change & 8.1 & -5.9 & -4.1 & 10.7 & 18.2 \\
\hline Import-GDP ratio (in percent) & 27.9 & 27.9 & 28.4 & 24.6 & 24.8 \\
\hline Merchandise imports, f.o.b. & 18.7 & 18.5 & 18.6 & 15.9 & 17.8 \\
\hline Services imports & 9.1 & 9.5 & 9.9 & 8.6 & 7.0 \\
\hline Terms of trade $(1996=100)$ & 106.3 & 115.0 & 117.8 & 114.9 & 95.6 \\
\hline Percentage change & -7.8 & 8.1 & 2.4 & -2.4 & -16.8 \\
\hline
\end{tabular}

Sources: Guinean authorities; and IMF staff estimates. 
Table 18. Guinea: Direction of Trade-Exports, 2000-04

\begin{tabular}{|c|c|c|c|c|c|}
\hline & 2000 & 2001 & 2002 & 2003 & 2004 \\
\hline & \multicolumn{3}{|c|}{ (In percent of total) } & & \\
\hline Industrial countries & 78.5 & 84.3 & 58.5 & 55.6 & 49.2 \\
\hline \multicolumn{6}{|l|}{ Of which: } \\
\hline Spain & 7.6 & 10.3 & 10.3 & 10.5 & 12.3 \\
\hline United States & 11.5 & 17.7 & 9.4 & 9.9 & 7.6 \\
\hline France & 18.5 & 21.2 & 7.3 & 8.7 & 5.8 \\
\hline Ireland & 17.2 & 11.2 & 8.8 & 7.8 & 8.3 \\
\hline Belgium & 13.1 & 2.2 & 9.9 & 6.2 & 5.1 \\
\hline Germany & 5.3 & 6.9 & 5.1 & 5.5 & 6.1 \\
\hline Canada & 3.8 & 2.8 & 3.2 & 3.4 & 1.9 \\
\hline Netherlands & 0.0 & 1.3 & 0.6 & 1.3 & 0.2 \\
\hline United Kingdom & 1.4 & 8.1 & 0.5 & 0.3 & 0.5 \\
\hline Switzerland & 0.1 & 2.3 & 0.0 & 0.1 & 0.1 \\
\hline Developing countries & 21.5 & 15.7 & 41.5 & 44.4 & 50.8 \\
\hline Africa & 7.6 & 14.8 & 3.9 & 8.0 & 8.8 \\
\hline \multicolumn{6}{|l|}{ Of which: } \\
\hline Cameroon & 5.6 & 13.7 & 1.5 & 2.9 & 3.2 \\
\hline Côte d'Ivoire & 0.0 & 0.0 & 0.4 & 0.6 & 0.7 \\
\hline Liberia & 0.0 & 0.4 & 0.3 & 0.3 & 0.4 \\
\hline Nigeria & 0.0 & 0.0 & 0.6 & 2.8 & 3.1 \\
\hline Asia & 0.1 & 0.1 & 20.0 & 17.2 & 17.7 \\
\hline \multicolumn{6}{|l|}{ Of which: } \\
\hline Korea & 0.0 & 0.0 & 18.2 & 14.6 & 16.0 \\
\hline People's Republic of China & 0.0 & 0.0 & 1.3 & 1.2 & 0.0 \\
\hline Europe & 13.8 & 0.8 & 17.6 & 19.2 & 24.2 \\
\hline \multicolumn{6}{|l|}{ Of which: } \\
\hline Russia & 0.0 & 0.0 & 6.9 & 8.9 & 13.1 \\
\hline Ukraine & 11.2 & 0.3 & 6.8 & 5.2 & 5.7 \\
\hline Romania & 0.3 & 0.0 & 2.6 & 2.6 & 2.9 \\
\hline Middle East & 0.0 & 0.0 & 0.0 & 0.0 & 0.0 \\
\hline Western Hemisphere & 0.0 & 0.0 & 0.0 & 0.0 & 0.0 \\
\hline \multicolumn{6}{|l|}{ Memorandum items: } \\
\hline European Union & 65.2 & 61.5 & 46.0 & 42.9 & 40.4 \\
\hline
\end{tabular}

Source: IMF, Direction of Trade Statistics (DOTS), various years. 
Table 19. Guinea: Direction of Trade-Imports, 2000-04

\begin{tabular}{|c|c|c|c|c|c|}
\hline & 2000 & 2001 & 2002 & 2003 & 2004 \\
\hline & \multicolumn{3}{|c|}{ (In percent of total) } & & \\
\hline Industrial countries & 56.4 & 58.6 & 66.6 & 57.0 & 53.3 \\
\hline \multicolumn{6}{|l|}{ Of which: } \\
\hline France & 20.6 & 19.3 & 18.6 & 15.5 & 13.8 \\
\hline Belgium & 8.1 & 8.7 & 7.5 & 6.6 & 5.7 \\
\hline Italy & 3.0 & 2.9 & 8.8 & 6.1 & 4.4 \\
\hline Netherlands & 2.4 & 2.0 & 2.9 & 5.1 & 6.3 \\
\hline United Kingdom & 1.9 & 1.9 & 5.2 & 5.0 & 2.6 \\
\hline United States & 5.6 & 7.1 & 8.1 & 4.2 & 5.9 \\
\hline Germany & 3.2 & 2.5 & 3.4 & 3.5 & 2.9 \\
\hline Spain & 2.1 & 1.6 & 2.1 & 2.0 & 2.2 \\
\hline Japan & 5.2 & 5.3 & 2.6 & 1.8 & 1.4 \\
\hline Switzerland & 1.0 & 1.6 & 1.7 & 2.2 & 2.3 \\
\hline Developing countries & 43.4 & 41.3 & 33.4 & 43.0 & 46.7 \\
\hline Africa & 25.0 & 22.0 & 12.1 & 15.0 & 15.6 \\
\hline \multicolumn{6}{|l|}{ Of which: } \\
\hline Côte d'Ivoire & 17.9 & 17.3 & 5.3 & 4.5 & 5.1 \\
\hline Senegal & 0.6 & 0.9 & 2.1 & 3.4 & 3.8 \\
\hline South Africa & 2.2 & 1.9 & 1.4 & 5.0 & 4.3 \\
\hline Asia & 13.1 & 14.5 & 15.2 & 20.7 & 23.2 \\
\hline \multicolumn{6}{|l|}{ Of which: } \\
\hline People's Republic of China & 4.9 & 6.3 & 5.6 & 8.6 & 9.7 \\
\hline Hong Kong & 1.0 & 1.1 & 2.4 & 2.2 & 1.8 \\
\hline India & 2.0 & 1.9 & 1.2 & 4.2 & 4.7 \\
\hline Indonesia & 1.0 & 1.3 & 2.5 & 1.9 & 2.1 \\
\hline Korea & 0.3 & 0.3 & 1.2 & 1.0 & 1.1 \\
\hline Europe & 3.2 & 1.9 & 2.6 & 3.3 & 3.4 \\
\hline Middle East & 1.4 & 2.1 & 1.3 & 1.5 & 1.8 \\
\hline Western Hemisphere & 0.8 & 0.7 & 2.1 & 2.4 & 2.7 \\
\hline \multicolumn{6}{|l|}{ Memorandum items: } \\
\hline European Union & 44.5 & 42.4 & 53.7 & 48.1 & 42.8 \\
\hline Oil-exporting countries & 2.4 & 3.1 & 4.6 & 3.1 & 3.5 \\
\hline Non-oil developing countries & 41.0 & 38.2 & 28.8 & 39.9 & 43.2 \\
\hline
\end{tabular}

Source: IMF, Direction of Trade Statistics (DOTS), various years. 
Table 20. Guinea: External Public Debt, 2000-04 1/

\begin{tabular}{|c|c|c|c|c|c|}
\hline & 2000 & 2001 & 2002 & 2003 & 2004 \\
\hline & \multicolumn{4}{|c|}{ (In millions of U.S. dollars) } & \\
\hline \multicolumn{6}{|l|}{ Total medium- and long-term } \\
\hline debt outstanding & $3,261.0$ & $3,209.0$ & $3,045.6$ & $3,362.4$ & $3,270.3$ \\
\hline Medium- and long-term debt, excluding IMF & $3,148.1$ & $3,085.8$ & $2,906.6$ & $3,227.8$ & $3,154.6$ \\
\hline Multilateral institutions, excluding IMF & $1,555.7$ & $1,661.7$ & $1,740.3$ & $2,044.0$ & $1,907.6$ \\
\hline Organizations of Arab countries & 146.8 & 126.6 & 115.7 & 112.9 & 120.5 \\
\hline Bilateral creditors $1 /$ & $1,435.6$ & $1,289.5$ & $1,042.6$ & $1,062.9$ & $1,088.6$ \\
\hline Paris Club & $1,167.6$ & $1,074.5$ & 827.6 & 847.9 & 873.6 \\
\hline Postcutoff & 297.3 & 276.5 & 279.0 & 307.3 & 342.3 \\
\hline Rescheduled in 1986 and not previously rescheduled & 74.1 & 63.7 & 54.4 & 41.5 & 29.9 \\
\hline Rescheduled in 1989 & 61.8 & 45.0 & 34.4 & 22.1 & 22.3 \\
\hline Rescheduled in 1992 & 111.3 & 101.4 & 104.7 & 117.5 & 120.2 \\
\hline Rescheduled in 1995 & 98.2 & 92.2 & 96.0 & 109.1 & 110.6 \\
\hline Rescheduled in 1997 & 83.9 & 76.7 & 79.4 & 87.6 & 88.7 \\
\hline Russian Federation & 441.0 & 418.9 & 179.6 & 162.8 & 159.0 \\
\hline Other bilateral creditors & 268.0 & 215.0 & 215.0 & 215.0 & 215.0 \\
\hline Commercial creditors & 10.0 & 8.0 & 8.0 & 8.0 & 37.9 \\
\hline Outstanding IMF credit & 112.9 & 123.3 & 139.0 & 134.6 & 115.6 \\
\hline Memorandum items: & \multicolumn{4}{|c|}{ (In percent of GDP) } & \\
\hline Total debt & 104.8 & 105.6 & 94.9 & 92.6 & 82.4 \\
\hline Medium- and long-term debt, excluding IMF & 101.1 & 101.5 & 90.5 & 88.9 & 79.5 \\
\hline IMF credit & 3.6 & 4.1 & 4.3 & 3.7 & 2.9 \\
\hline
\end{tabular}

Sources: Guinean authorities; and IMF staff estimates.

$1 /$ Guinean debt to some bilateral and multilateral creditors is not fully reconciled. A data reconciliation exercise will be conducted in the context of the Heavily Indebted Poor Countries (HIPC) Initiative completion point review. 
Table 21. Guinea: External Debt Service, 2000-04

\begin{tabular}{|c|c|c|c|c|c|}
\hline & 2000 & 2001 & 2002 & 2003 & 2004 \\
\hline \multicolumn{6}{|c|}{ (In millions of U.S. dollars) } \\
\hline Debt service due before debt rescheduling $1 /$ & 143.8 & 161.7 & 146.0 & 184.2 & 197.6 \\
\hline Interest & 55.6 & 32.4 & 37.9 & 43.1 & 54.3 \\
\hline Principal & 88.2 & 129.3 & 108.1 & 141.1 & 143.3 \\
\hline Of which: IMF repurchases & 8.0 & 11.8 & 11.3 & 16.4 & 22.5 \\
\hline Debt rescheduling & 0.0 & 48.1 & 27.9 & 46.1 & 34.8 \\
\hline Debt service due after debt rescheduling & 143.8 & 113.5 & 118.1 & 110.6 & 162.8 \\
\hline & \multicolumn{5}{|c|}{ (In percent of exports of goods and services) } \\
\hline \multicolumn{6}{|l|}{ Memorandum items: } \\
\hline Debt service due before debt rescheduling & 19.6 & 20.0 & 18.6 & 22.8 & 24.0 \\
\hline Debt service due after debt rescheduling & 19.6 & 14.0 & 15.0 & 13.7 & 19.8 \\
\hline
\end{tabular}

Sources: Guinean authorities; and IMF staff estimates.

$1 /$ Government and public enterprises. 
Table 22. Guinea: Debt-Service Liabilities on Medium- and Long-Term External Public Debt, 2000-04

(In millions of U.S. dollars)

\begin{tabular}{|c|c|c|c|c|c|}
\hline & 2000 & 2001 & 2002 & 2003 & 2004 \\
\hline Total debt service due (excluding IMF) & 152.3 & 158.6 & 149.5 & 140.6 & 166.9 \\
\hline Interest due on medium- and long-term public debt & 38.8 & 39.0 & 50.9 & 37.9 & 47.8 \\
\hline International organizations $1 /$ & 13.7 & 17.9 & 21.5 & 18.9 & 25.3 \\
\hline Organizations of Arab countries & 1.4 & 2.2 & 2.2 & 2.6 & 2.3 \\
\hline Paris Club, post-cutoff date & 5.8 & 5.2 & 4.8 & 4.3 & 4.6 \\
\hline Paris Club, 1986 and previously rescheduled debt (PRD) & 1.1 & 0.9 & 0.9 & 0.8 & 1.1 \\
\hline Paris Club, 1989 & 4.1 & 2.8 & 1.9 & 1.0 & 0.9 \\
\hline Paris Club, 1992 & 4.1 & 3.8 & 3.6 & 3.2 & 4.7 \\
\hline Paris Club, 1995 & 3.3 & 2.9 & 2.8 & 2.6 & 3.3 \\
\hline Paris Club, 1997 & 3.3 & 1.2 & 3.1 & 2.7 & 3.7 \\
\hline Russian Federation 2/ & 2.0 & 1.9 & 10.0 & 1.8 & 1.8 \\
\hline Non-Paris Club bilaterals & 0.0 & 0.1 & 0.1 & 0.0 & 0.0 \\
\hline Bank and suppliers & $\ldots$ & $\ldots$ & $\ldots$ & $\ldots$ & $\ldots$ \\
\hline Principal due on medium- and long-term public debt (excluding IMF) & 113.5 & 119.6 & 98.6 & 102.7 & 119.1 \\
\hline Of which: International organizations $1 /$ & 43.1 & 37.6 & 44.6 & 45.0 & 53.2 \\
\hline Paris Club, post-cutoff-date & 13.6 & 16.6 & 15.7 & 16.9 & 23.5 \\
\hline Russian Federation 2/ & 22.1 & 22.1 & 3.6 & 10.1 & 4.2 \\
\hline Non-Paris Club bilaterals 2/ & 4.9 & 8.5 & 7.6 & 8.2 & 8.3 \\
\hline \multicolumn{6}{|l|}{ Memorandum items: } \\
\hline Change in debt-service payments arrears & 18.0 & 0.1 & -2.3 & 18.1 & 48.7 \\
\hline Interest & 3.1 & -0.1 & -1.4 & 4.6 & 11.7 \\
\hline Principal & 14.9 & 0.2 & -0.8 & 13.5 & 37.0 \\
\hline
\end{tabular}

Sources: Guinean authorities; and IMF staff estimates.

1/ Excluding organizations of Arab countries.

2/ Debt to some bilateral creditors is not fully reconciled; the table follows the Guinean position. 
Table 23. Guinea: Nominal Exchange Rates and Effective Exchange Rate Indices, 2000:Q1-2004:Q4

(Index, 1990=100, unless otherwise indicated)

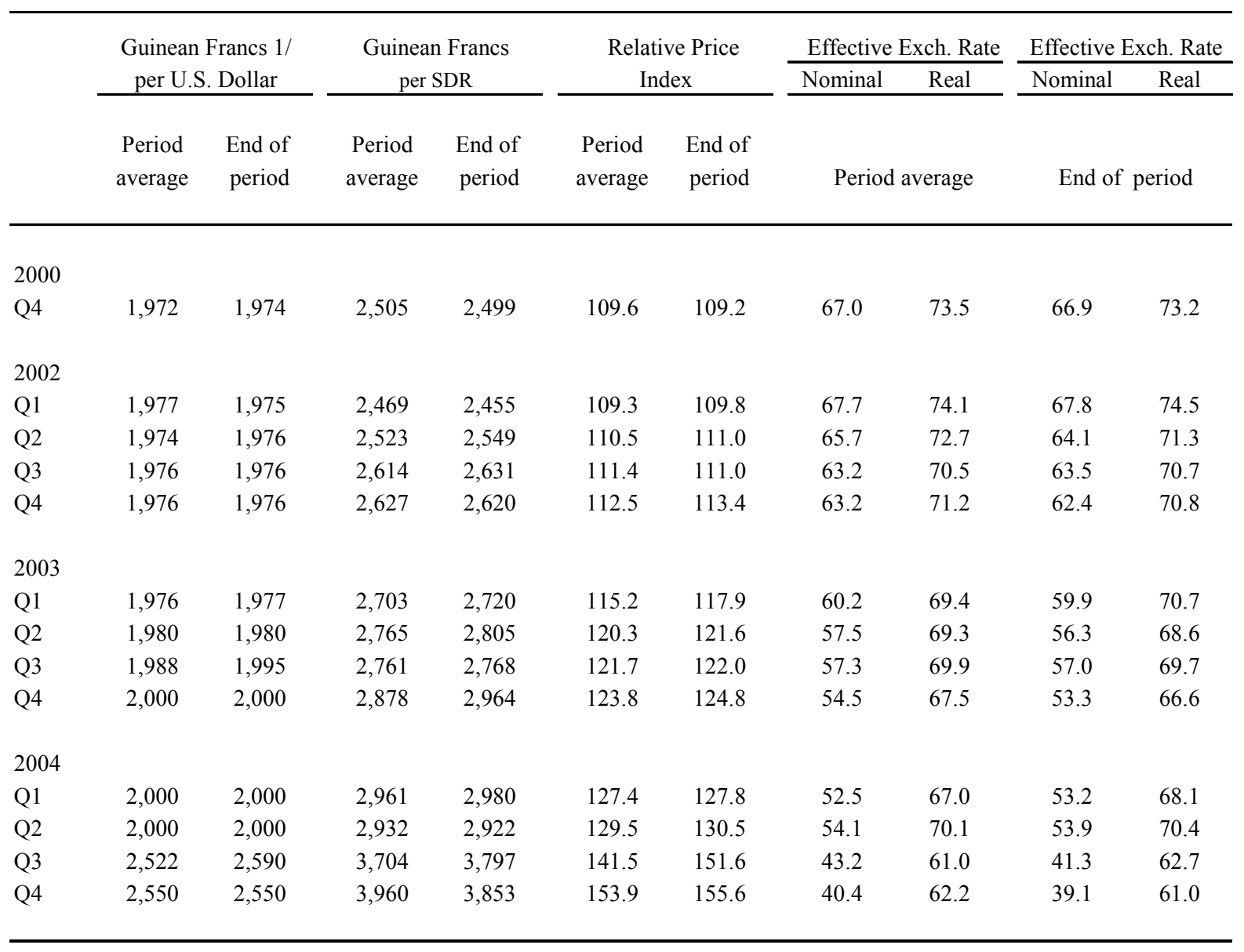

Sources: Guinean authorities; IMF, International Financial Statistics and Information Notice System; and staff estimates.

1/ Official exchange rate. 


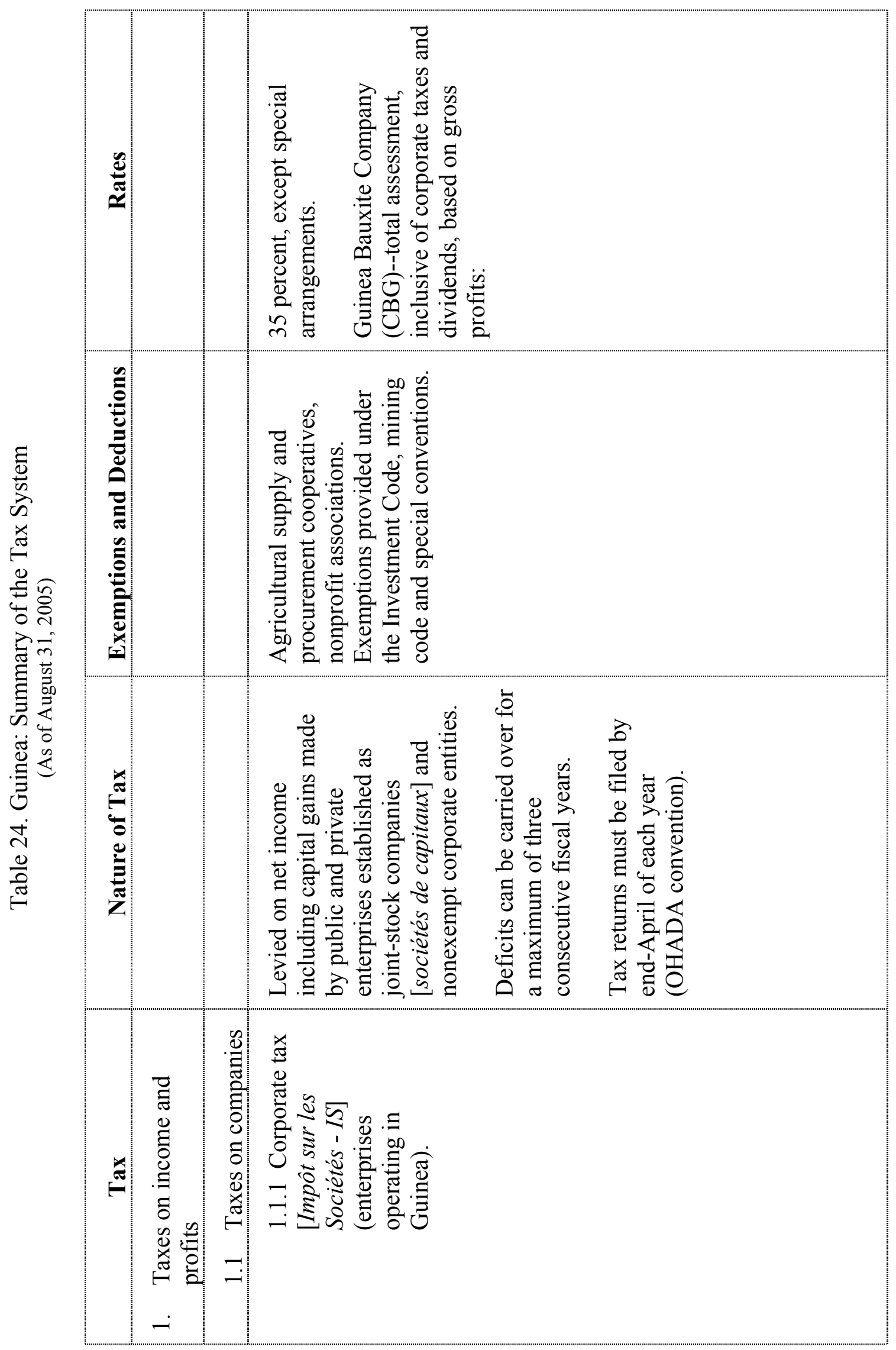




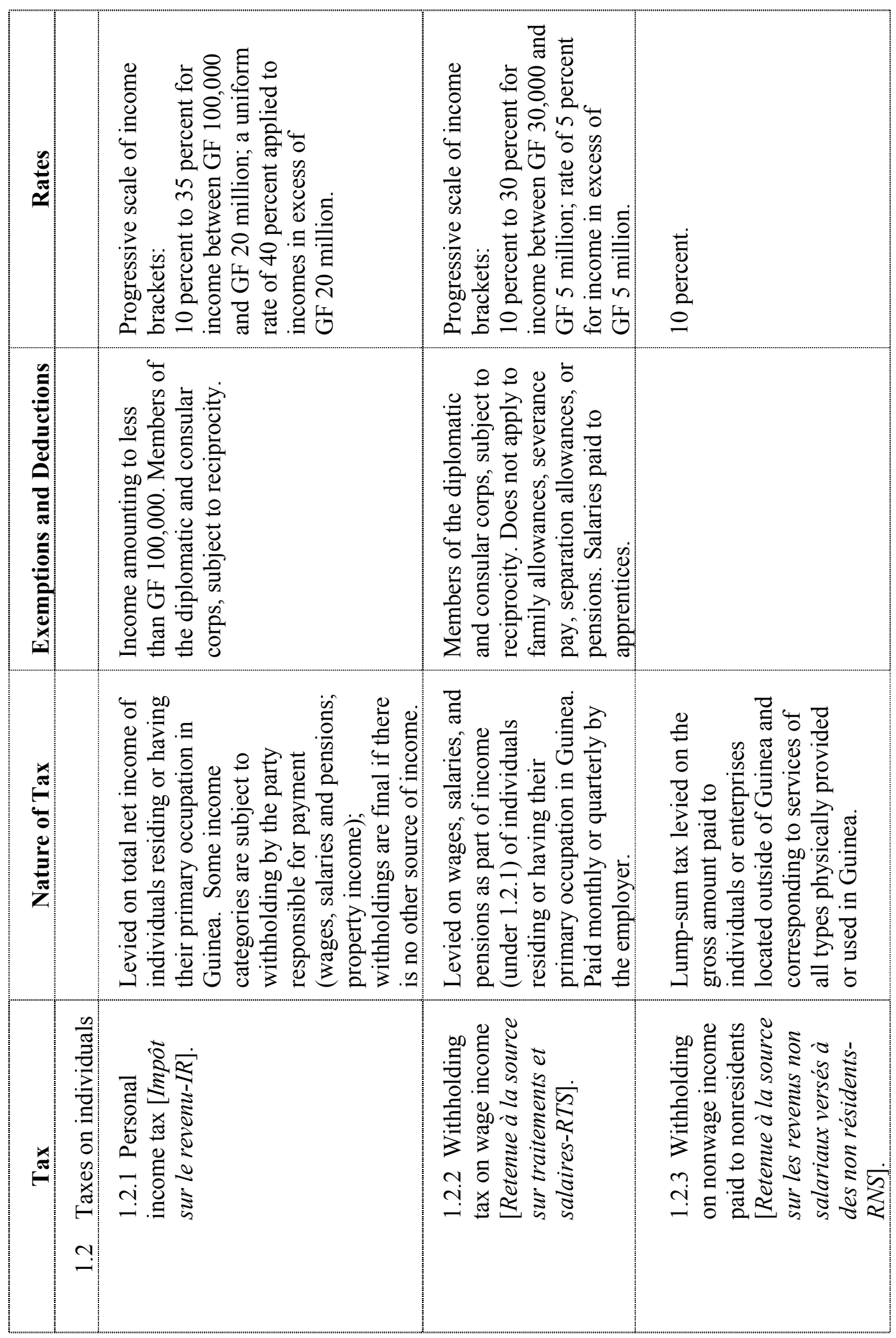




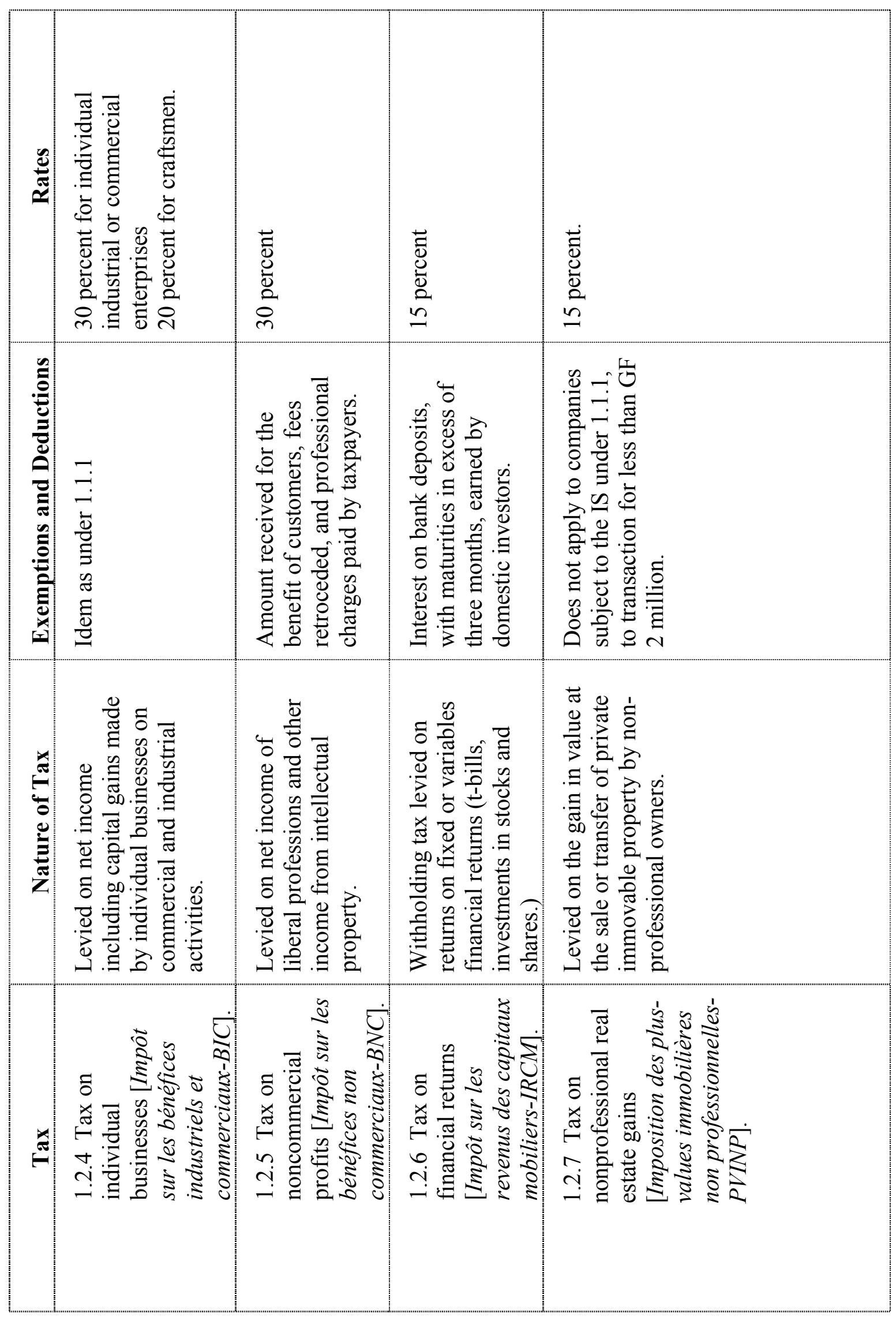




\begin{tabular}{|c|c|c|c|c|}
\hline 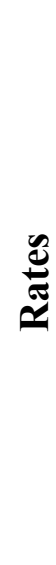 & 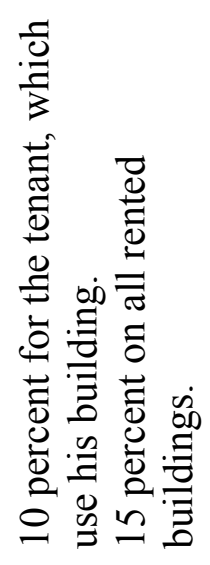 & 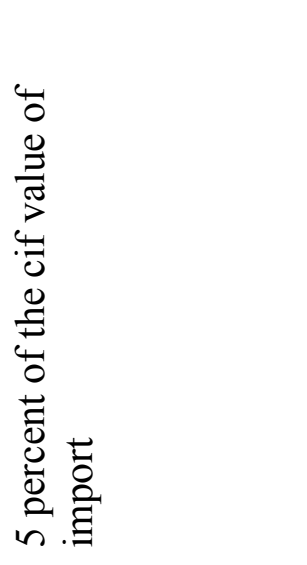 & 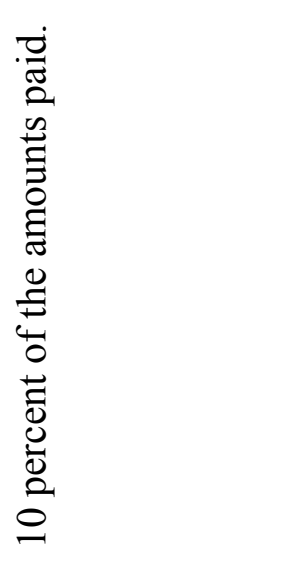 & 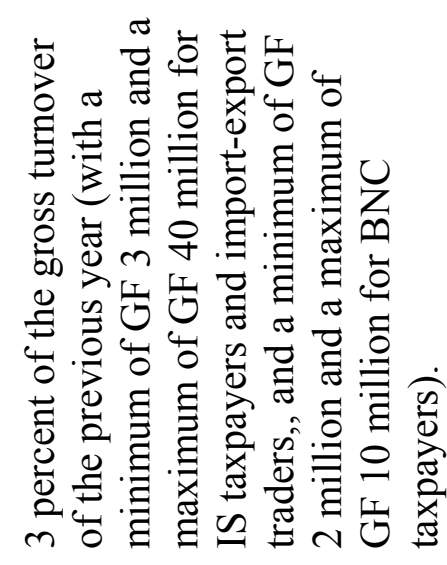 \\
\hline 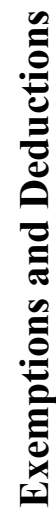 & 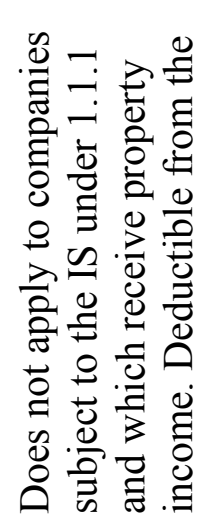 & 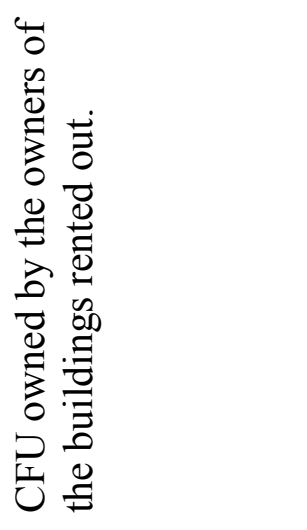 & 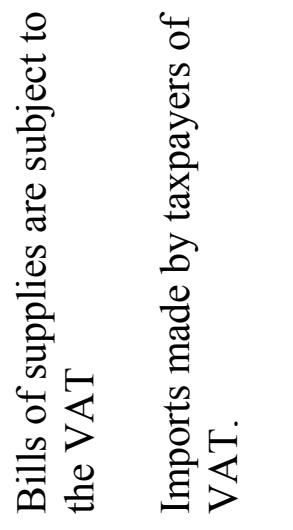 & 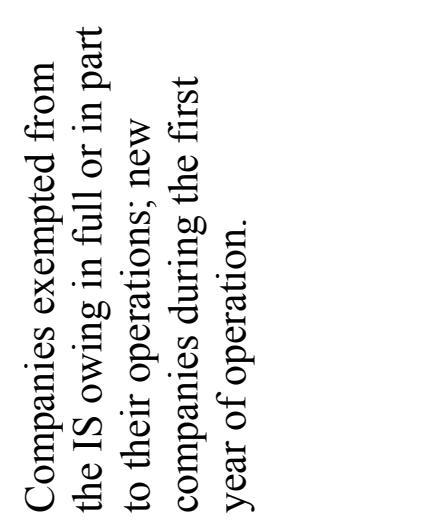 \\
\hline 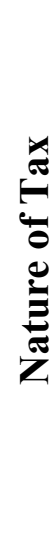 & 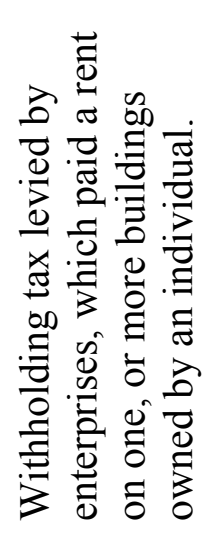 & 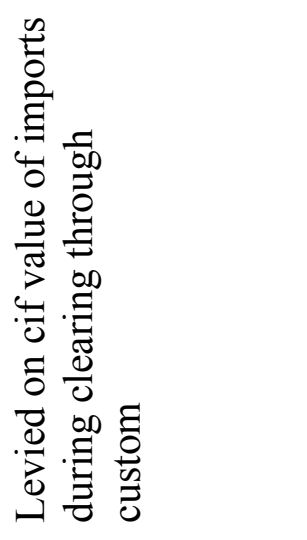 & 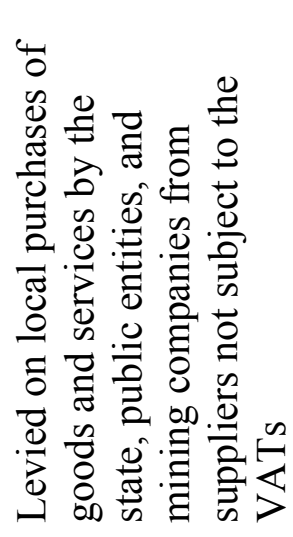 & 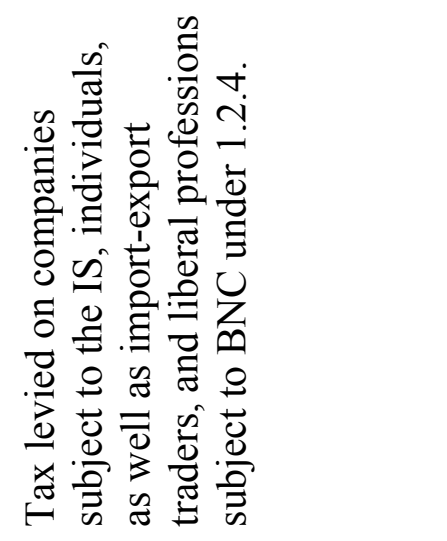 \\
\hline$\tilde{\sigma}$ & 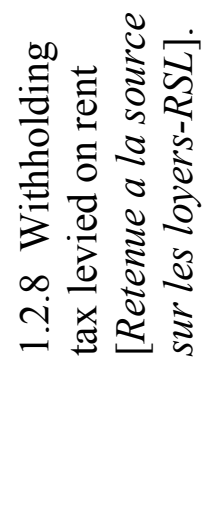 & 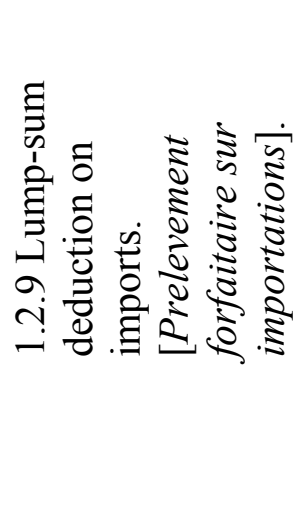 & 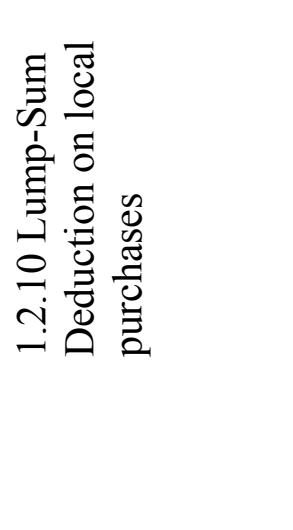 & 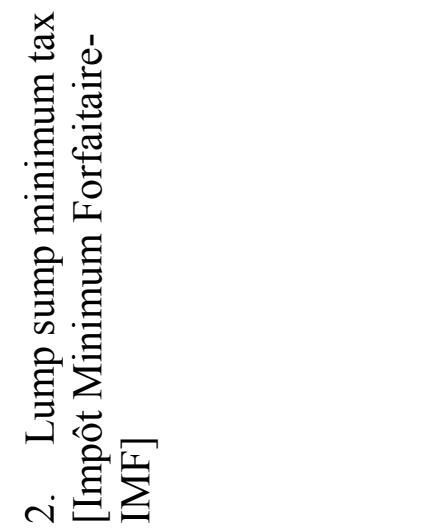 \\
\hline
\end{tabular}




\begin{tabular}{|c|c|c|c|c|c|c|}
\hline 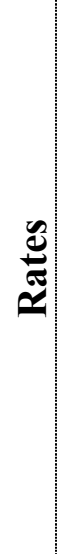 & & 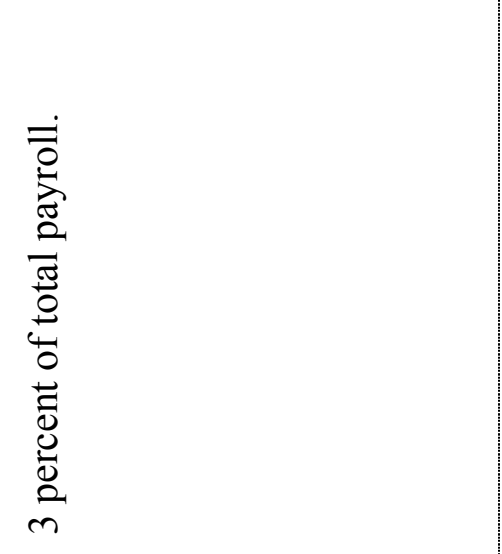 & 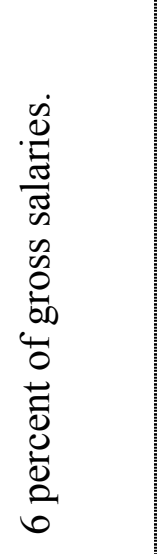 & & 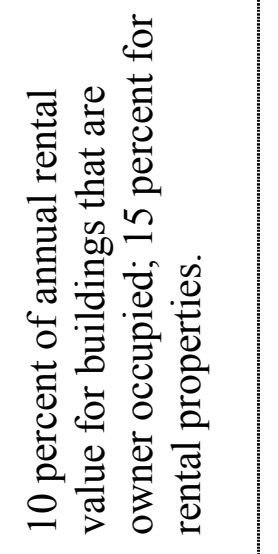 & 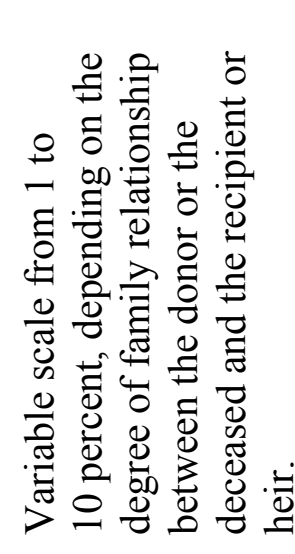 \\
\hline 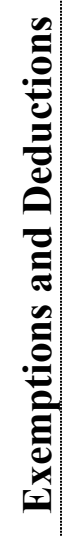 & & 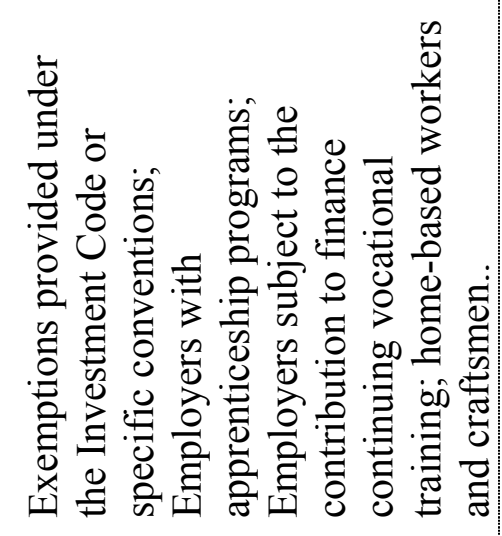 & & & 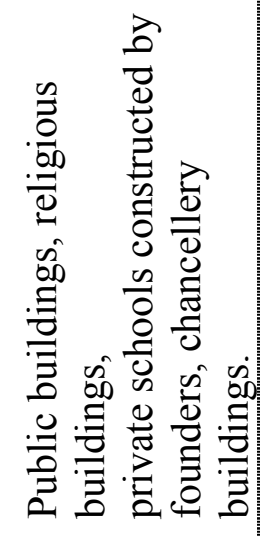 & 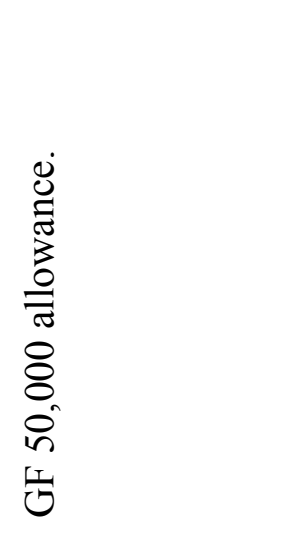 \\
\hline 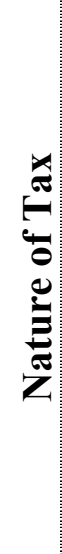 & & 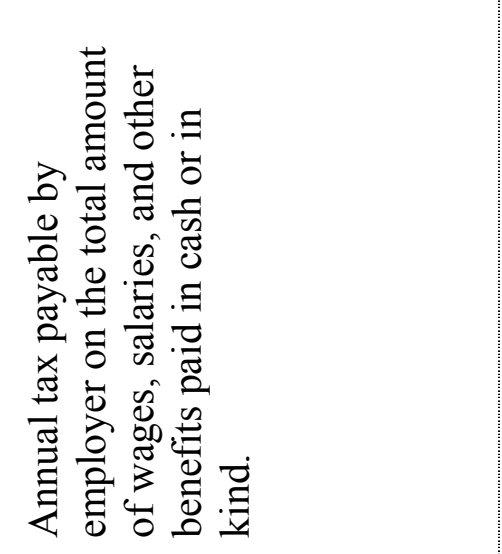 & 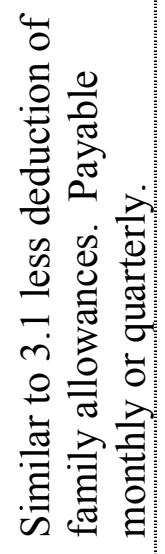 & & 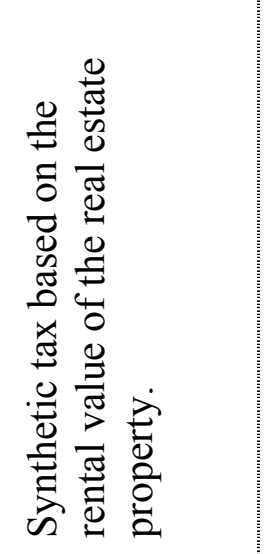 & 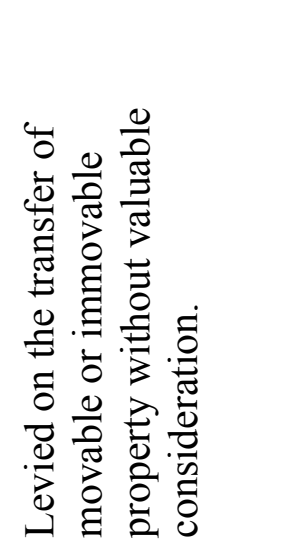 \\
\hline$\stackrel{\pi}{\mathbb{E}}$ & 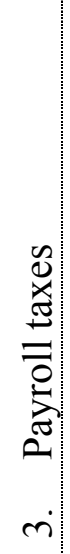 & 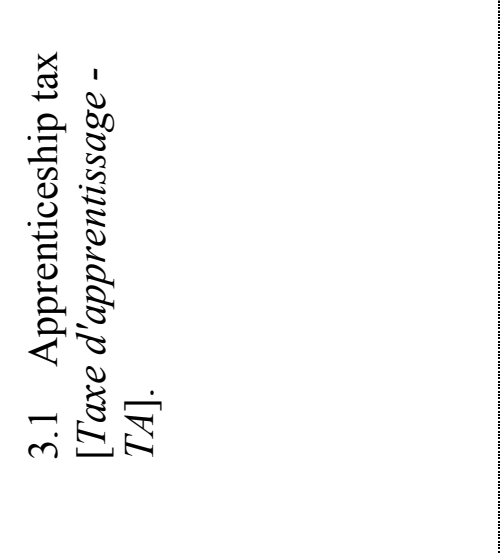 & 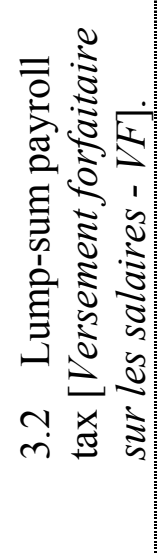 & 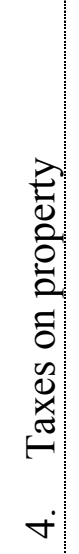 & 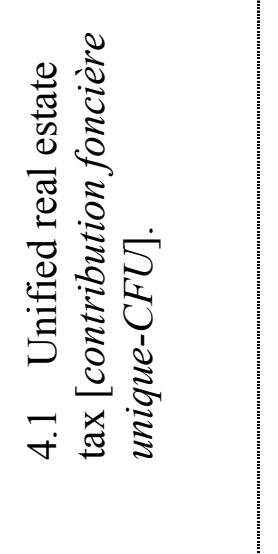 & 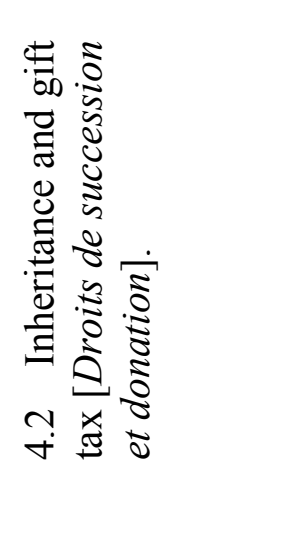 \\
\hline
\end{tabular}




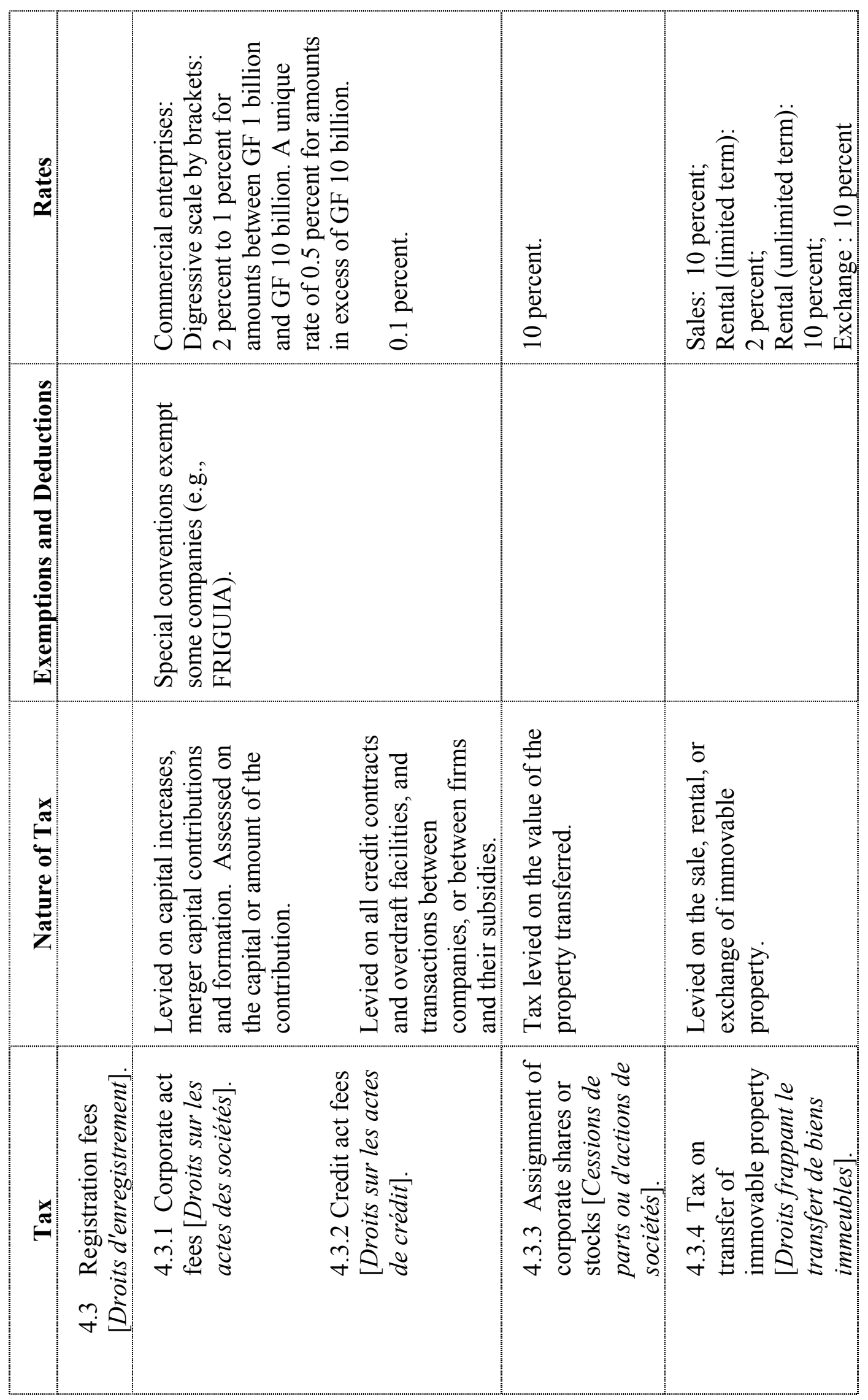




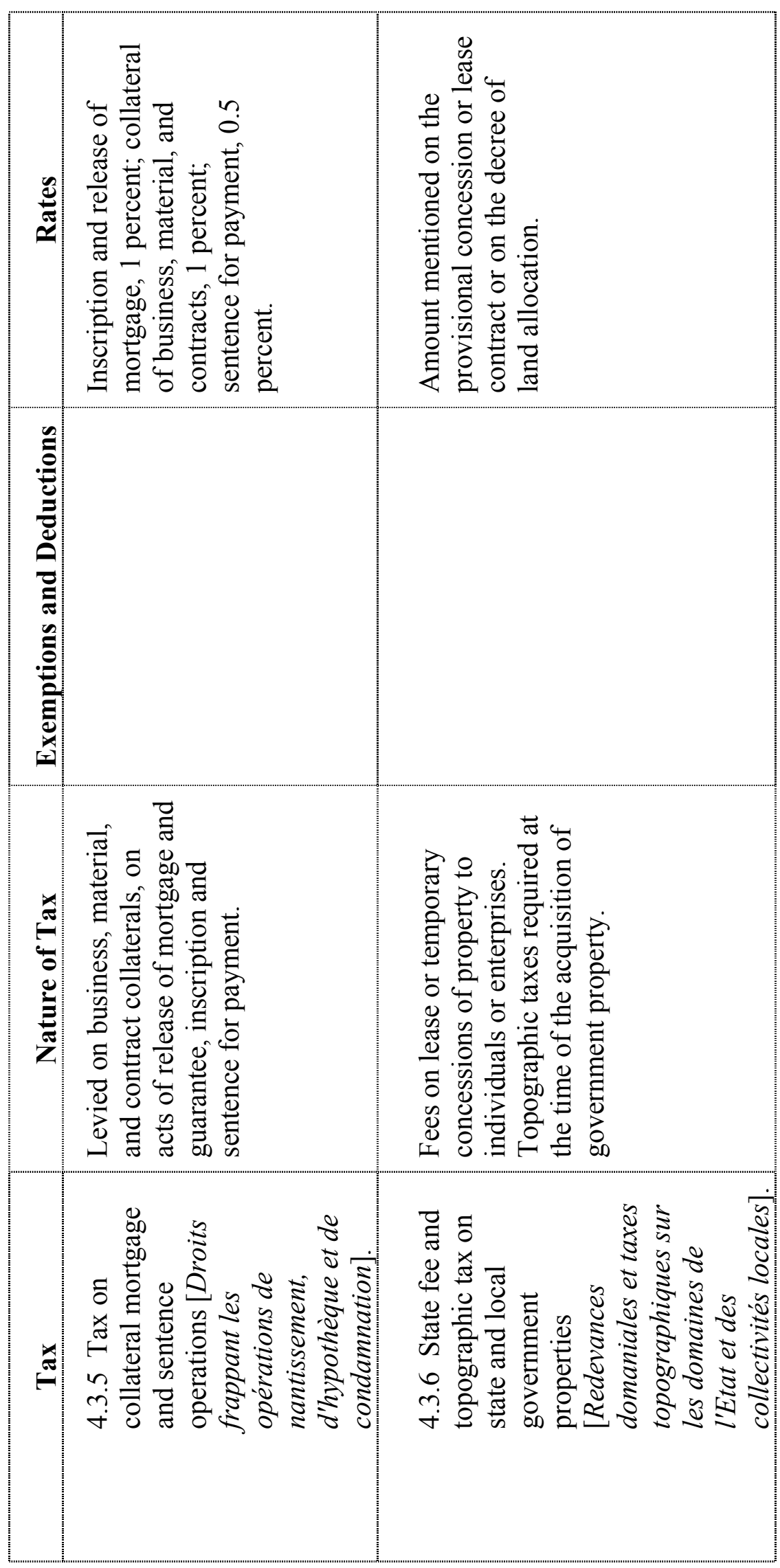




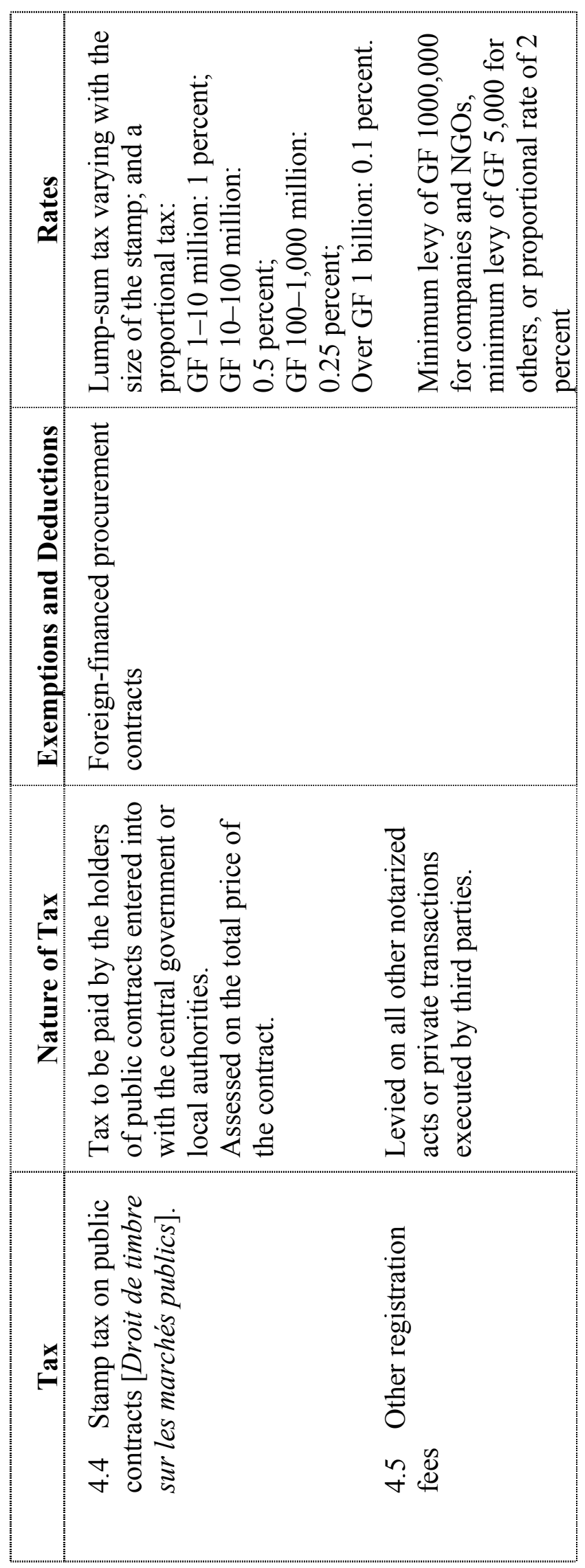




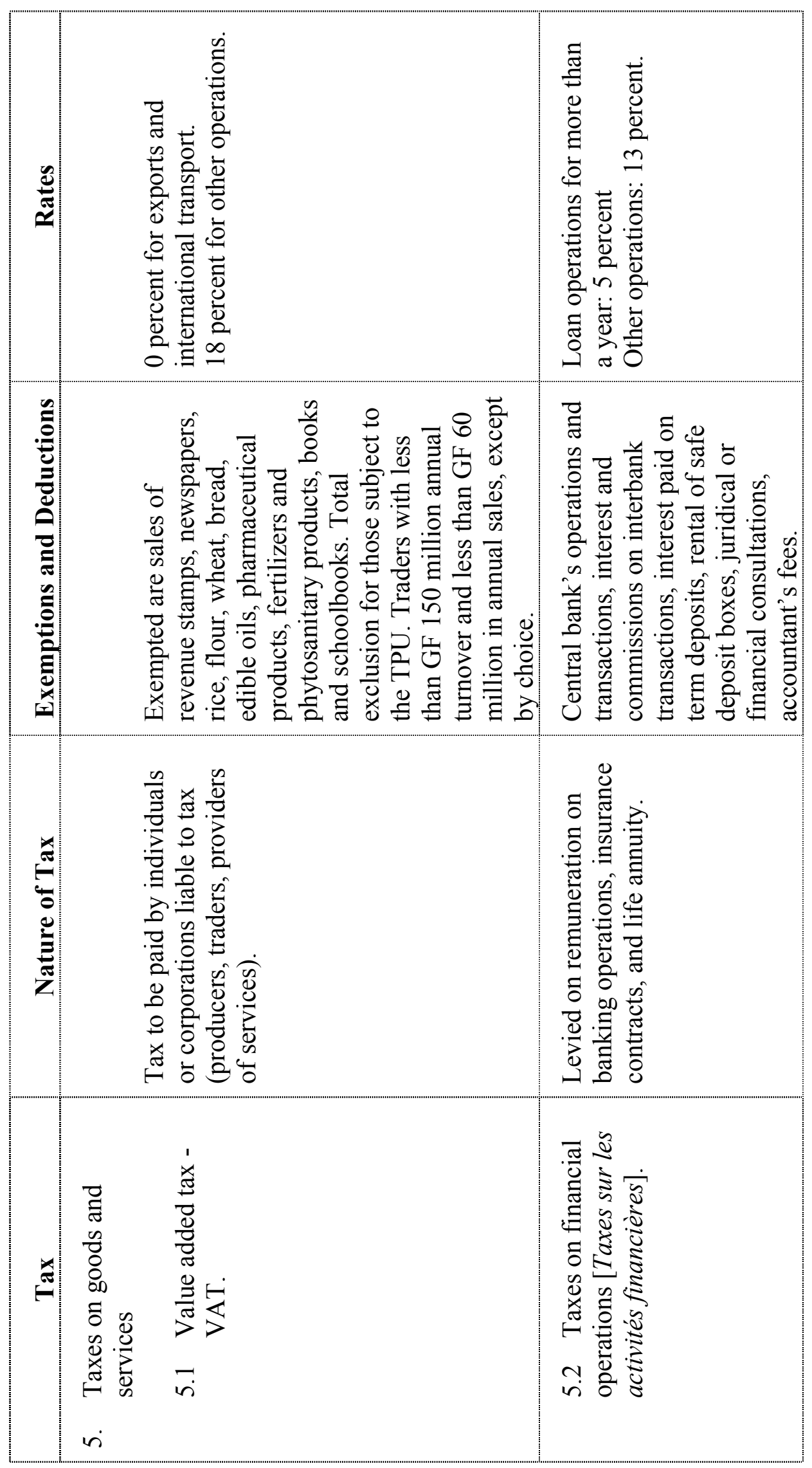




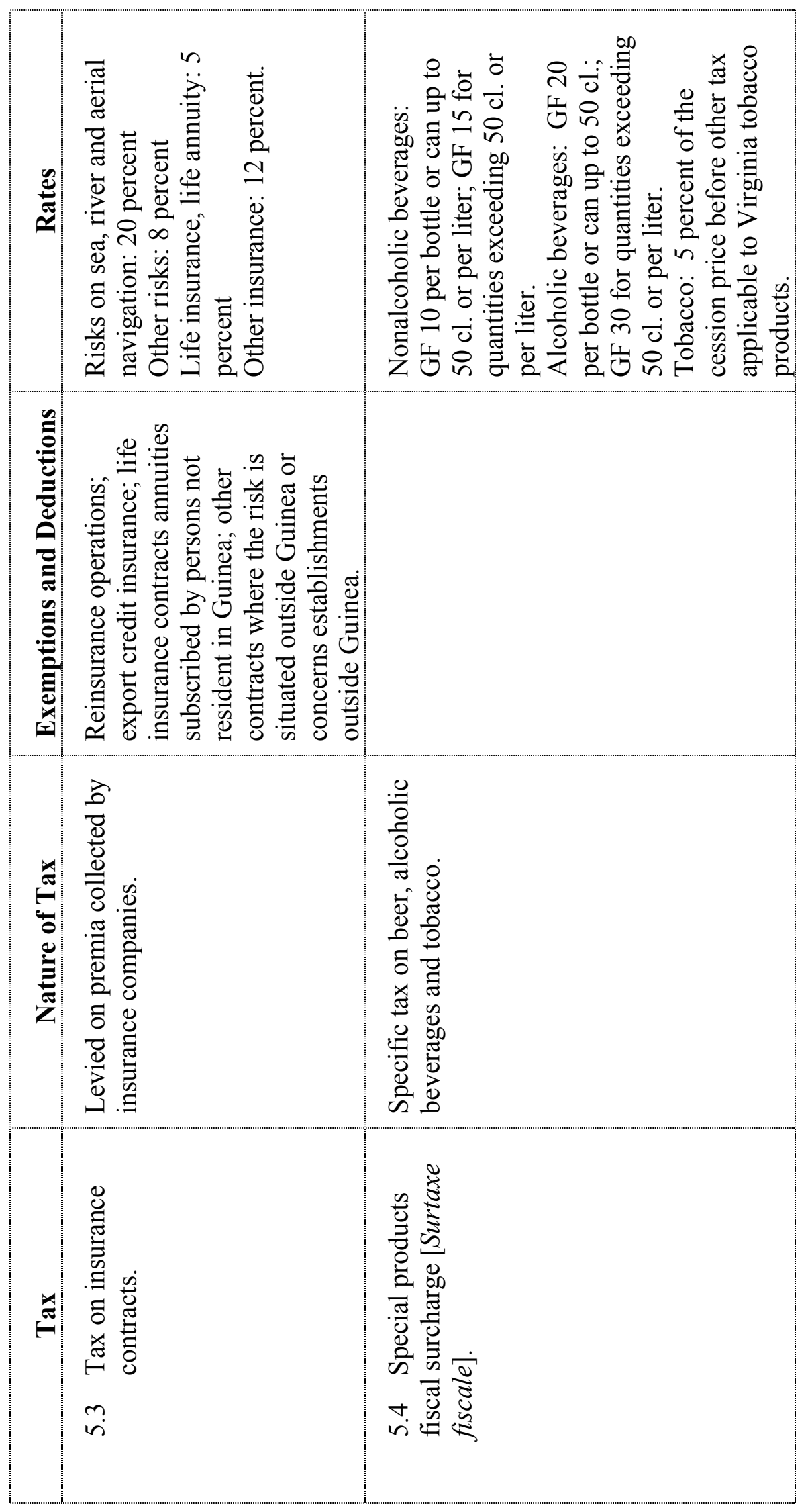




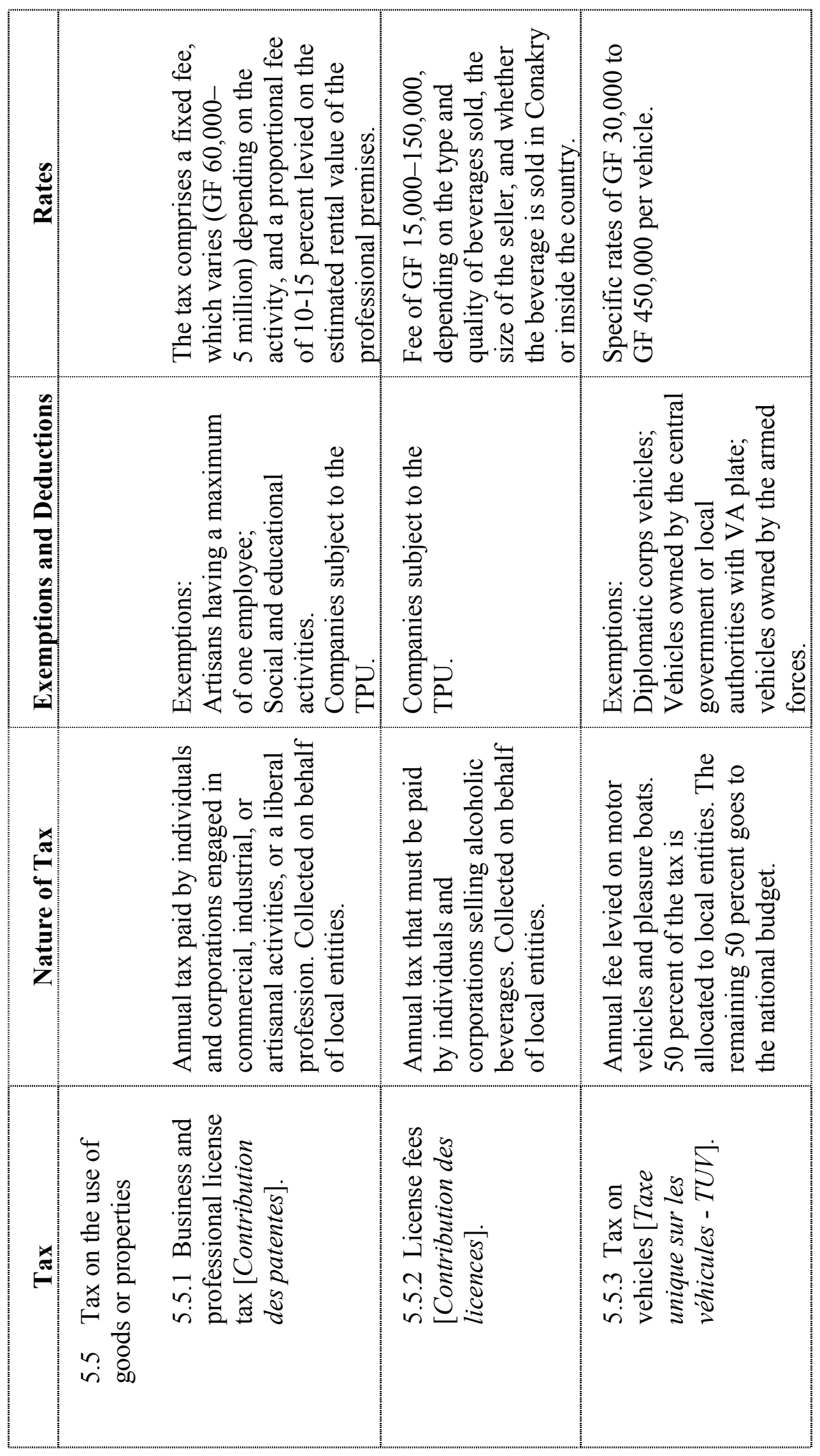




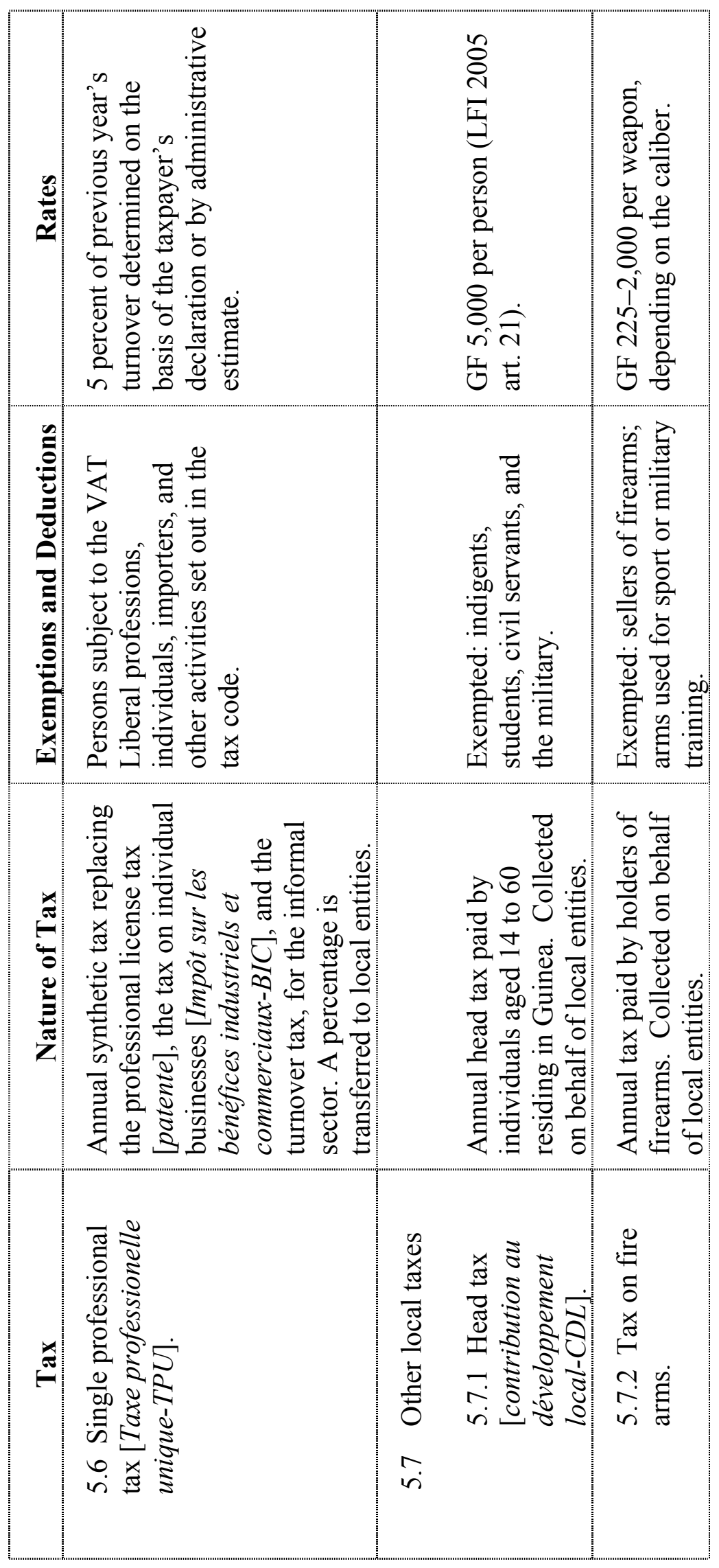




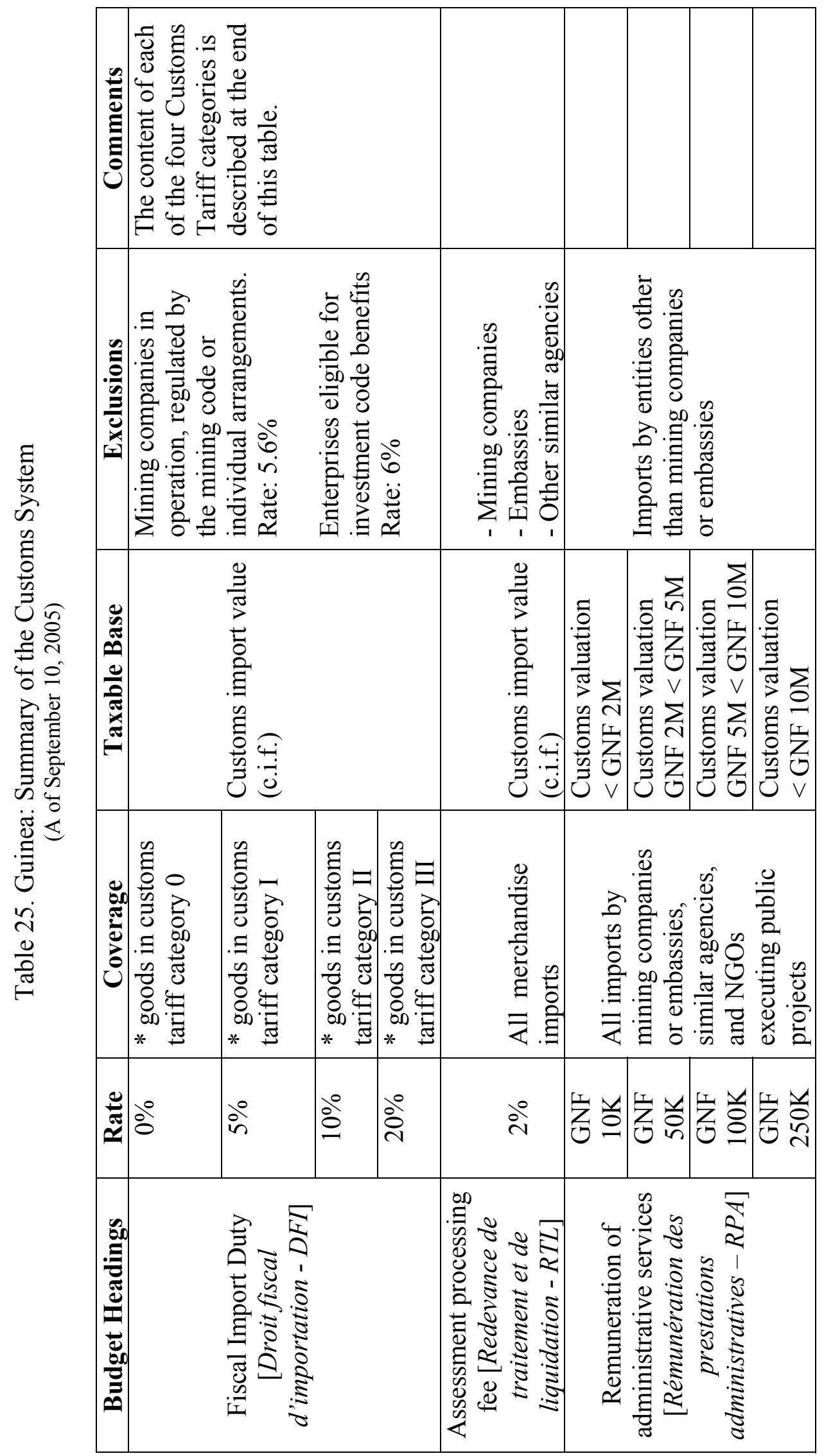




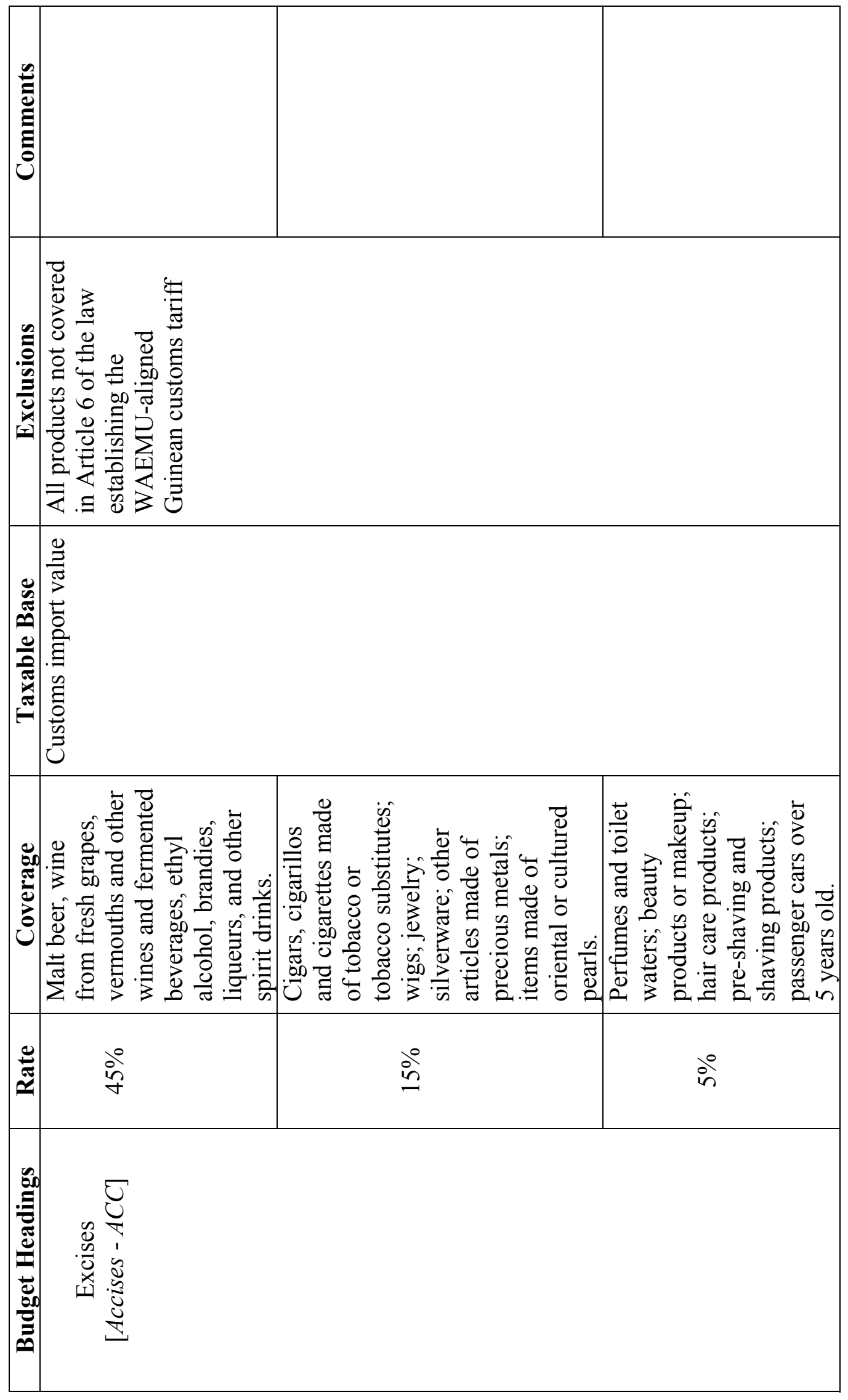




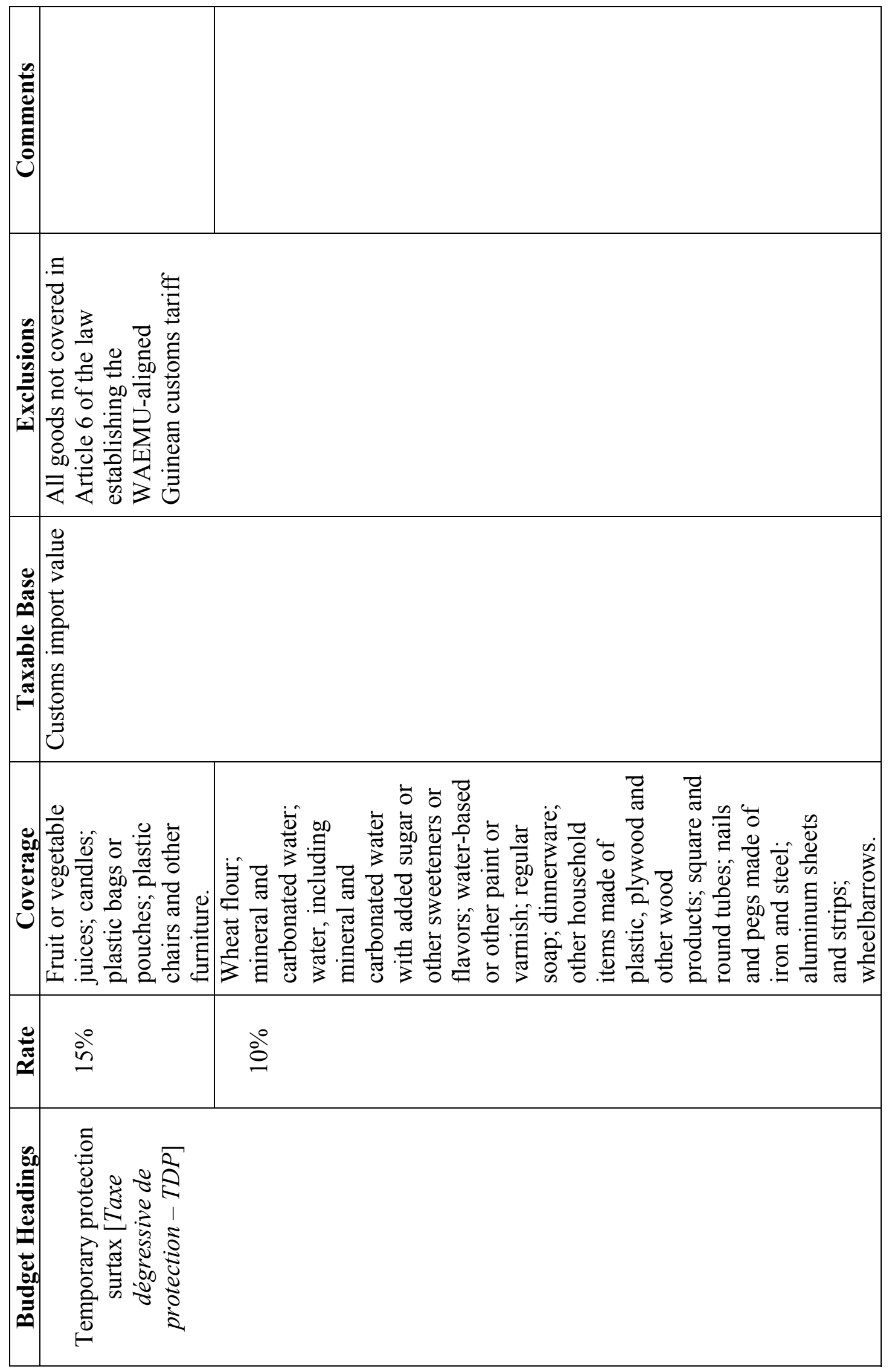




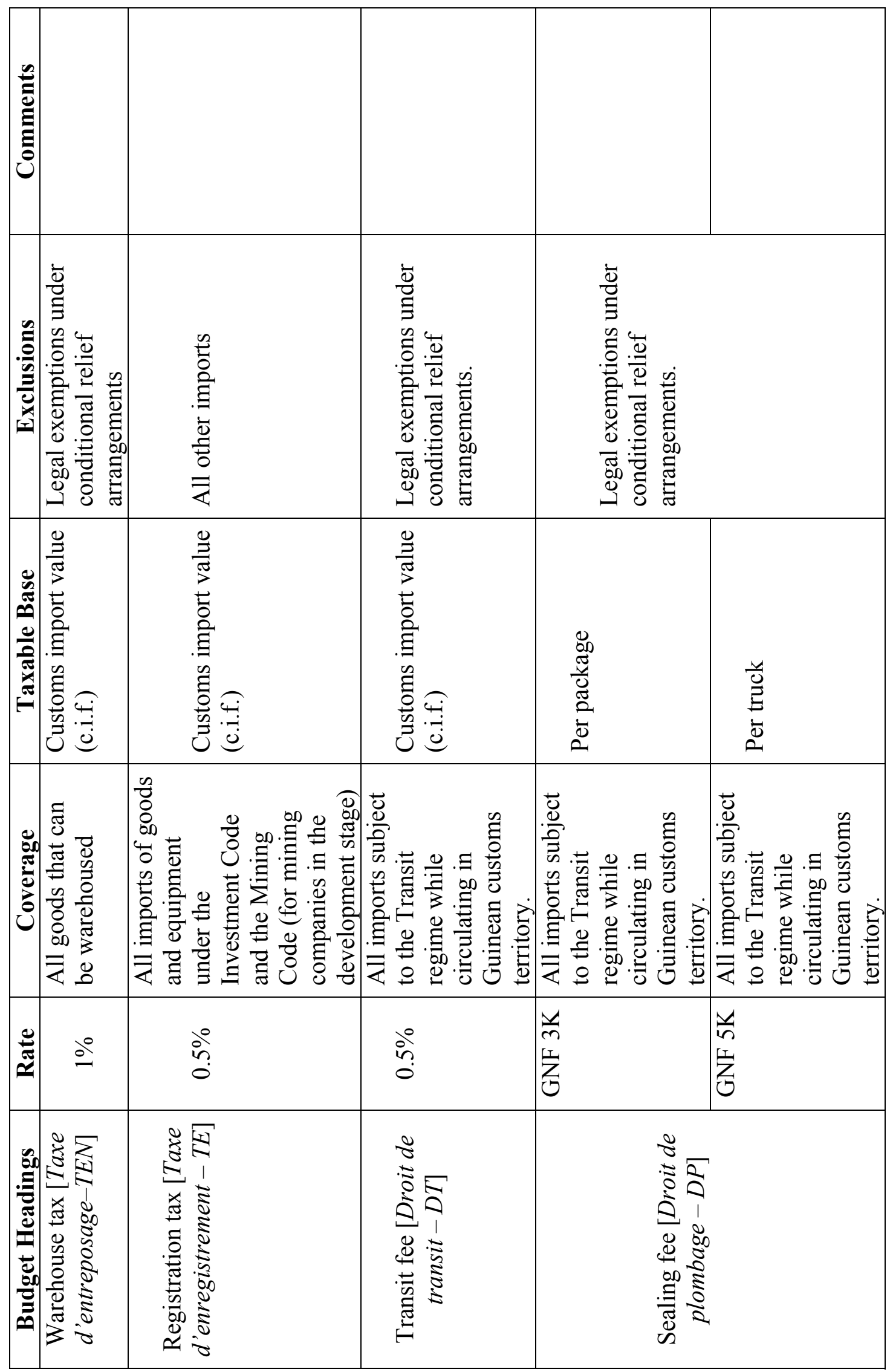




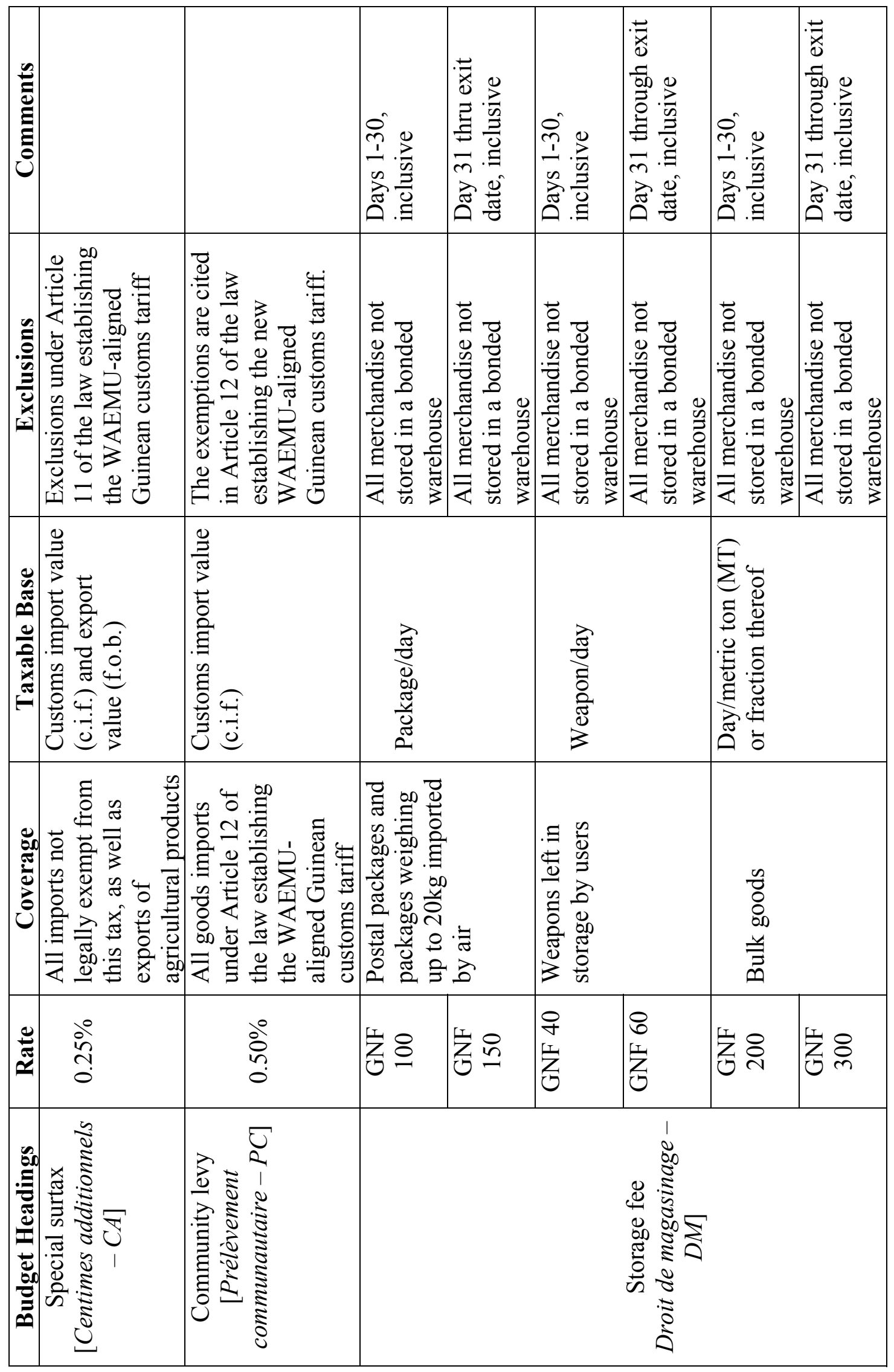




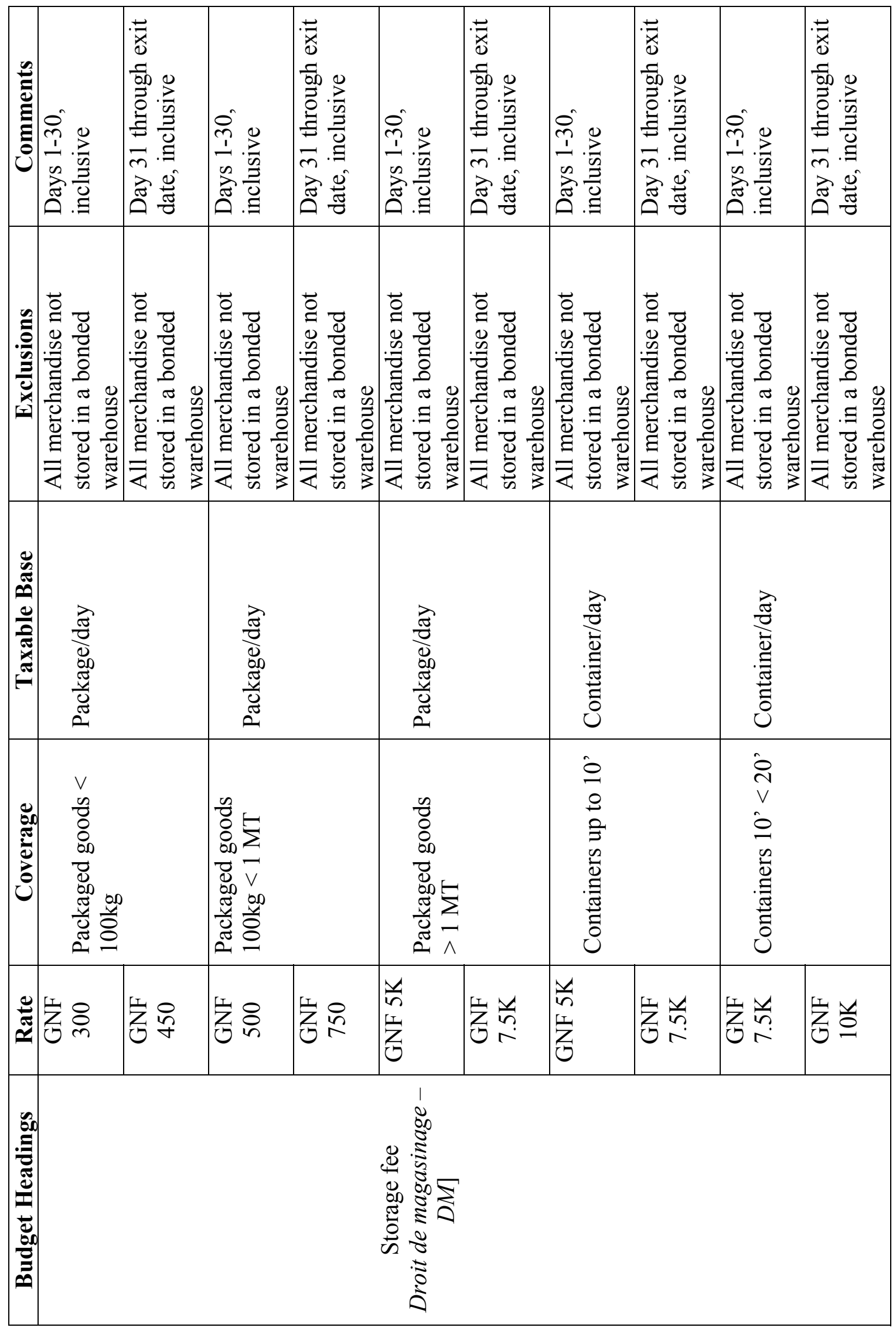




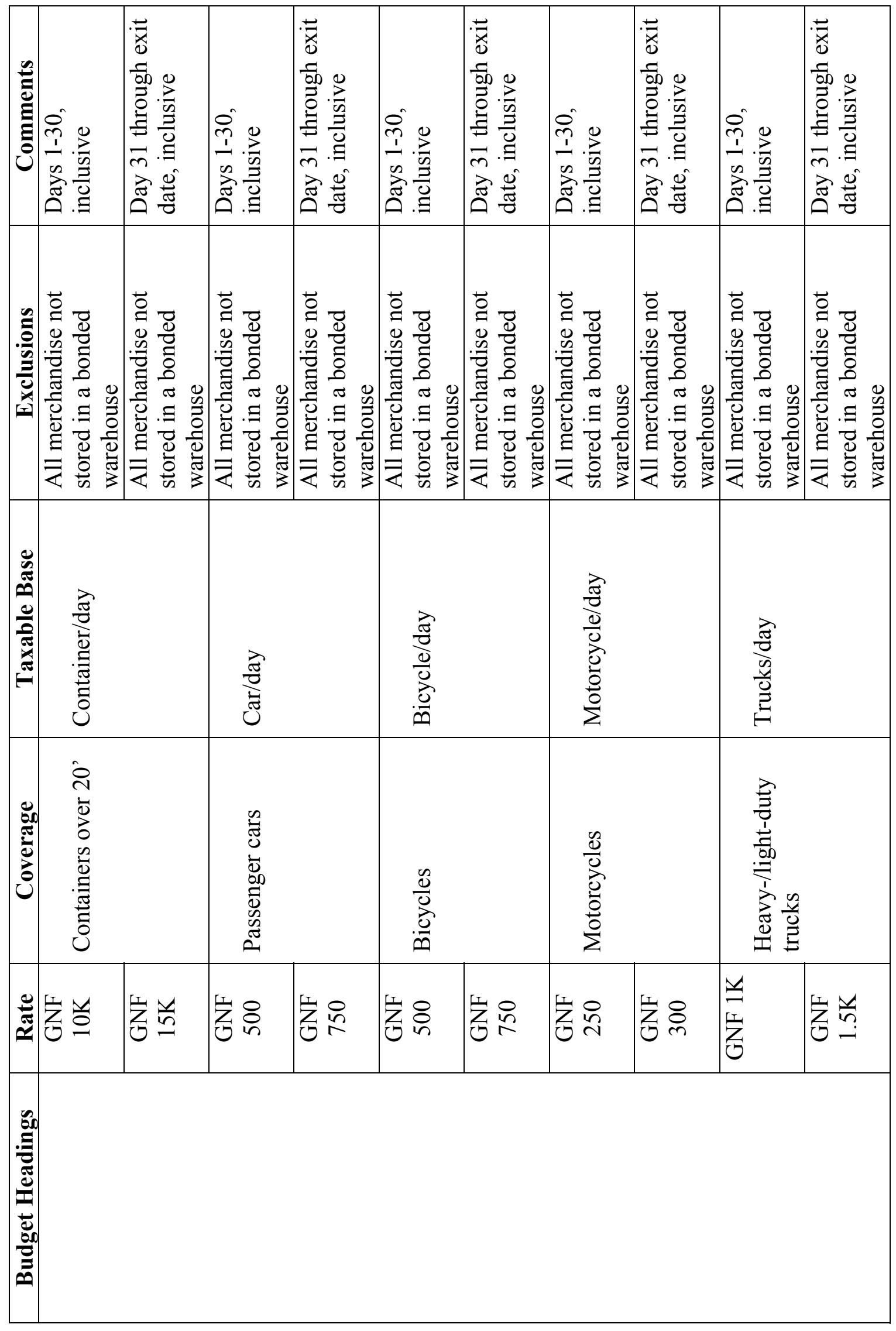




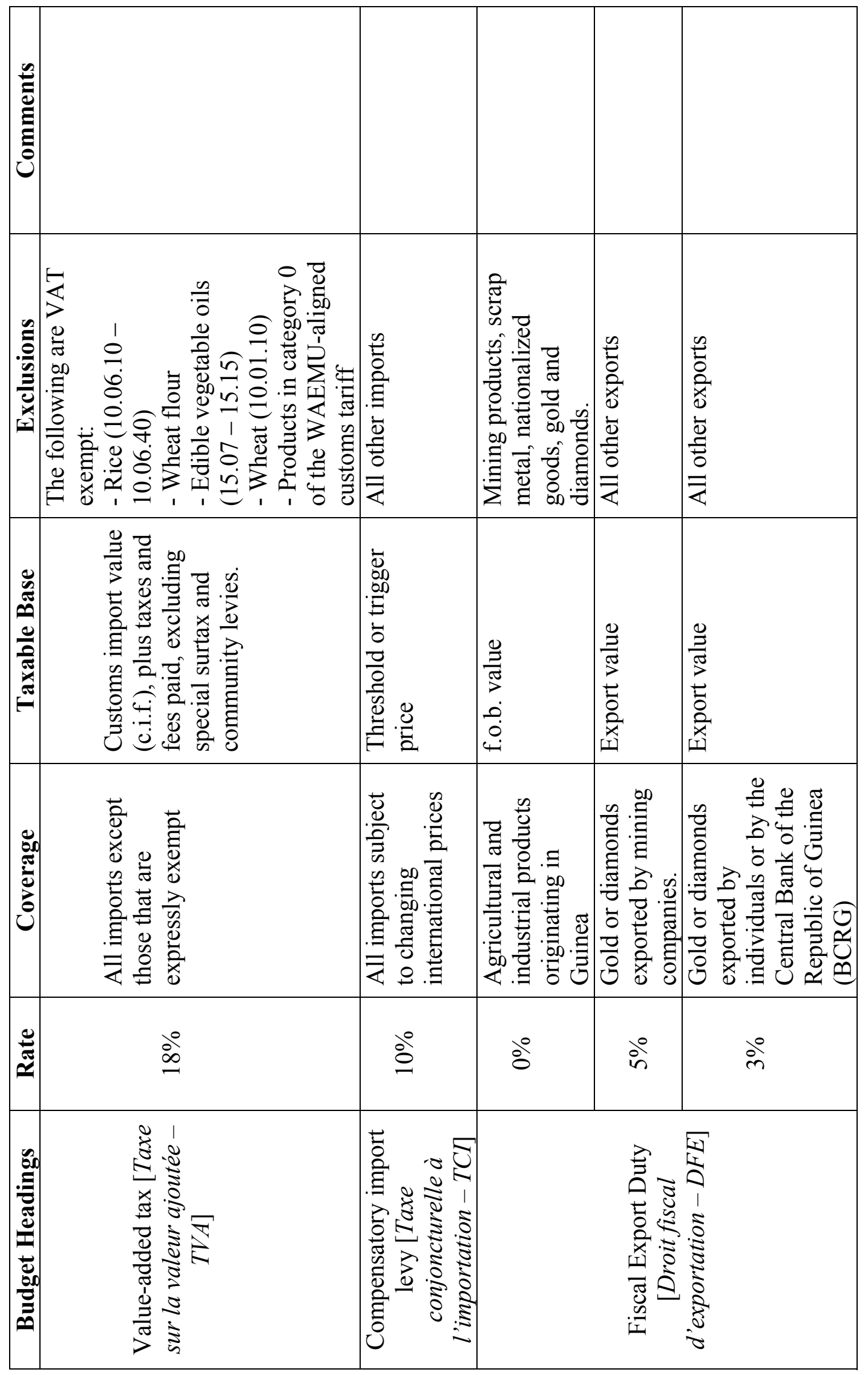




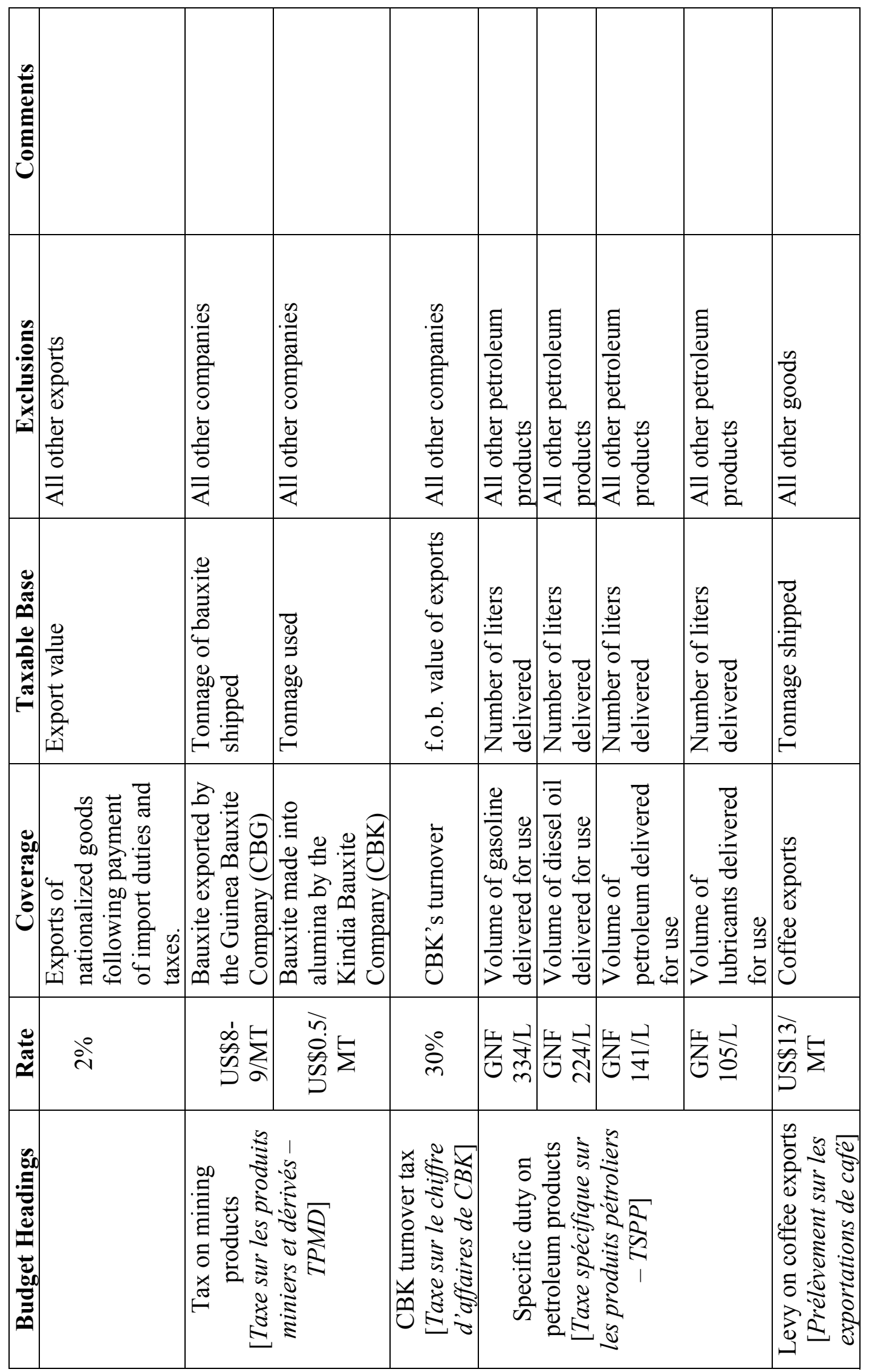




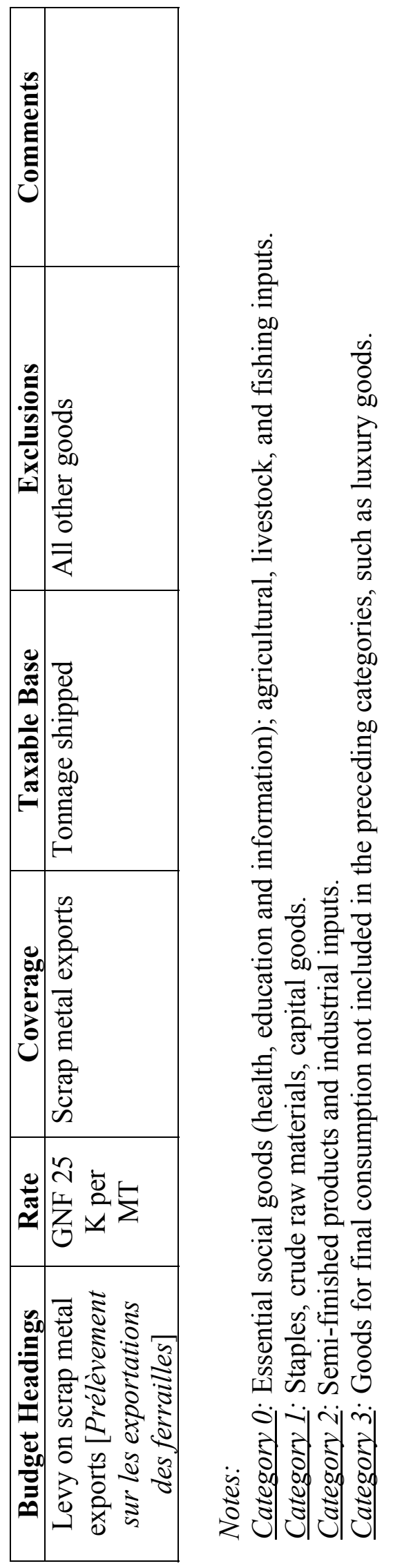

